\title{
LOCAL MONOPOLY IN THE DAILY NEWSPAPER INDUSTRY
}

CONCENTRATION of ownership in mass communications industries is a prominent fact in American life. ${ }^{1}$ In the more modern mass media, eight major studios dominate film production. ${ }^{2}$ A majority of AM radio stations and a large percentage of television outlets are affiliates of five major radio and TV networks. ${ }^{3}$ In more traditional media, a handful of publishers supplies the bulk of popular magazine circulation. ${ }^{4}$ And a few dozen regional and national chains own newspapers which account for almost half of total daily circulation and more than half of total Sunday circulation. ${ }^{5}$ Though government agencies in recent years have challenged this pattern, concentration persists. ${ }^{6}$

1. For general discussion, see 2 Chafee, Government and MAss Comaunications (1947); Commission on Freedom of the Press, A Free and Responsinle Putss (1947); Ernst, The First Freedom (1946). See also Hualues, Prejudice and tile Press (1950) (reply to: Mr. Ernst and the Commission).

2. See Brady, The Problem of Monopoly in Motion Pictures, in Mass CommuniCation 168 (Schramm ed. 1949); Commission on Freedom of tue Press, op. cil. supra note 1, at 41-2; see also.INGLis, FreEDon of tHe Movies (1947).

3. Of 2183 AM stations in operation in 1949, StepMaNN, Radto, Television AND Society 46 (1950), 1136 were affiliated with Mutual, ABC, CBS, or NBC. Comment, The Impact of the FCCI's Chain Broadcasting Rules, 60 YALE L.J. 78,93 n.75 (1951). And of 62 communities served by TV stations in 1950, 40 were interconnected; most stations in these communities were affiliated with one or more of the four TV networks: Dumont, $\mathrm{ABC}, \mathrm{NBC}$ and CBS. Id. at 102 .

4. See Commission on Freedom of the Press, op. cit. supra note 1, at 38-9.

5. A "chain" is defined as a newspaper ownership possessing two or more units in different cities. Nixon, Concentration and Absenteeism in Daily Newspaper Onncrship, 22 Jours. Q. 97, 105 (1945). In 1945, 76 chains owned 370 dailies (21.2 per cent of the total) accounting for approximately 43 per cent of total daily circulation; 32.9 per cent of all Sunday papers were chain-owned, and these accounted for 53.8 per cent of total Sunday circulation. $I d$. at 106,109 . As of 1949 , there were 70 chains controlling 386 dailies. Ray, Economic Forces as Factors in Daily Nezespaper Concentration, 29 JouRN. Q. 31, 32-3 (1952). Chain growth in recent years has tended to be intensive rather than extensive. Total number of dailies owned by the two largest national chains, Hearst and ScrippsHoward, has declined since 1935. Yet during the same period the number of state-wide or regional chains has multiplied. In 1945, 44 of the 76 chains were confined to one state. Nixon, supra, at 106-110.

6. In the motion picture industry, government activity has focused on competitive restraints in exhibition and distribution rather than in production. Sec United States $v$. Paramount Pictures, Inc., 334 U.S. 131 (1948); United States v. Griffith, 334 U.S. 100 (1948); Schine Theatres, Inc. v. United States, 334 U.S. 110 (1948). For analysis of these and other cases and critique of past government action, see McDonough \& Winslow, The Motion Picture Industry: United States v. Oligopoly, 1 Stan. L. REv. 385 (1949).

In the radio industry, the FCC's Chain Broadcasting Rules, 47 CODE Fep. Re(is. $\$ \$ 3.101-109$ (AM), 3.231-40 (FM), 3.631-40 (TV) (Supp. 1950), were "designed to curb the growing power of the networks and to eliminate specific restraints embodicd in contracts between the networks and their member stations." Comment, The Impact of the FCC's Chain Broadcasting Rulles, 60 Y ALE L.J. 78 (1951). For opinion that "[t]he impact of the Rules on the industry has been slight," see id. at 79, 87-98. 
On the level of the local community, concentration in daily newspaper control is almost universal. Although entry of dailies into previously vacant localities created new one-paper towns, ${ }^{7}$ newspaper merger, mortality, and combination have been the principal factors in a 20th Century trend toward single-publisher communities. Newspaper disappearances resulting from outright suspension, shift into less-than-daily operation, or consolidation of two units into one, ${ }^{3}$ ended multiplicity of newspapers in many cities. ${ }^{\circ}$ Replacements for deceased dailies came infrequently, for birth-rate of dailies failed to match death-rate; ${ }^{10}$ despite increasing nation-wide circulation, ${ }^{11}$ the total number of dailies fell by one-fourth between 1909 and 1950.12 Thus today

7. Total number of cities with one or more daily newspapers:

\begin{tabular}{lllllll} 
Year & 1909 & 1920 & 1930 & 1937 & 1945 & 1951 \\
\hline Cities & 1207 & 1295 & 1402 & 1460 & 1394 & 1443
\end{tabular}

Sources: ERnSt, The First Freedoas 284 (1946); Nixun, supra note 5, at 101 ; EDitur \& Publisher International Yeareook (1952) (hereinafter cited as Ed. \& Pub. YearBOOK).

8. "Consolidation" or "merger" as used herein means the amalgamation of two dailies into a single daily. "Combination" means the common ownership of two or more distinct dailies in a single community.

9. Analysis of 576 daily newspaper disappearances between December 31,1929 , and December 31, 1944, showed that 276 were eliminated through "outright suspension," 165 were "merged and dropped," and 135 went from daily to less frequent publication. Statistics by American Newspaper Publishers Association, in Nixon, supra note 5, at 99.

10. 598 dailies were started between 1929 and 1950 , but only 225 were still in business in 1950. Meanwhile, 374 dailies in existence at the start of the 1929-1950 period disappeared by 1950 . Thus the net change between 1929 and 1950 was a loss of 149 daily newspapers. American Newspaper Publishers Association Bulletin No. 5203, July 27, 1950.

11. Total daily circulation has grown even faster than gopulation or literate population in the United States. Between 1909 and 1951 total circulation ruse from 24,211,977, Lee, The Daily Newspaper in Amserica 726 (1937), to 54,017,938, Ed. \& Pub. YensBOOK (1952), an increase of 123 per cent. In the same period, population increased 71 per cent. U.S. Census data. Literate population increased about 57 per cent. U.S. Census data Yet daily newspaper circulation may be currently on the downswing of a cycle. Davenport, Trends and $C_{y y c l e s}$ in Daily Nearspaper Circulation, 27 Jouks. Q. 282, 287 (1950).

12. Number of dailies in actual numbers and as a percentage of total dailies in 1909:

\begin{tabular}{llllll} 
Year & 1909 & 1921 & 1931 & 1939 & 1947 \\
\hline Dailies & 2600 & 2335 & 2044 & 2040 & 1854 \\
\hline$\%$ of 1909 & 100 & 90 & 79 & 78 & 71
\end{tabular}

Source: U.S. Census data, in LeE, The DAIIy Newspaper IN Ayrerica 719 (1937) and in Census of Mlanufacturers 1947, op. cit. infra note 127, at 9.

Varying definitions of "daily newspaper," however, cause discrepancies in statistics provided by different sources for total number of dailies. See LEE, op. cit. stspra, at 705-9 (1937). But all data indicate a definite decline. See N.W. Ayer data in Enrst, Tre Funsr Freedons 279-80 (1946); Ed. \& Pub. Yearbook data in Friedsan, The Newsfrait ProsLear, table 13 (1948). See also note 20 infra.

Increase in total circulation and decrease in number of dailies is more marlied in the morning than in the evening field. Between 1925 and 1950 circulation of all evening papers 
more than 80 per cent of all cities served by local dailies have only one paper. ${ }^{10}$ Moreover, combination reduced multiplicity of ownerships by placing onceindependent dailies under single control. ${ }^{14}$ About ten per cent of newspapercities have two or more dailies owned by one publisher. ${ }^{15}$ Although remaining cities, ${ }^{10}$ where separate ownerships exist, are typically of metropolitan size

rose 47 per cent while number of evening papers declined by 9 per cent. Yet in the same period total morning circulation increased 68 per cent, while number of morning dailies dropped by 25 per cent. Ed. \& Pub. YeArzooK (1952); Editor \& Publisher, Aug. 11, 1951, p. 7 (hereinafter cited as Ed. \& Pub.). The disparity is attributable to the fact that morning papers, with more time than evening dailies for distribution, derive more advantage from modern transportation facilities, can thus spread from large cities into smaller neighboring communities and grow in circulation while crowding out smaller morning dailies. See LEE, op. cit. supra, at 67. Yet expansion of metropolitan morning dailies has not resulted in a greater increase of "monopoly" newspaper towns, sec note $19 \mathrm{infra}$, among "satellites" of metropolitan centers than among other communities. Neurath, OncPublisher Commmunities: Factors Infunencing Trend, 21 JounN. Q. 230, 240-1 (1944). Another reason for greater numerical decline of morning papers has been preference of advertisers in many communities for evening readership. Ray, Economic Forces as Factors in Daily Newespaper Concentration, 29 Jours. Q. 31, 33 (1952). And see notes 179, 180, 203 infra.

13. One-paper towns as a percentage of all cities with daily newspaper service:

\begin{tabular}{llllll} 
Year & 1909 & 1923 & 1928 & 1945 & 1951 \\
\hline Cities & $43 \%$ & $60 \%$ & $69 \%$ & $79 \%$ & $81 \%$
\end{tabular}

Sources: Ernst, The First Freedom 284 (1946); Ed. \& Pub., Aug. 18, 1928, p. 3; Nixon, supra note 5, at 101 ; Ed. \& Pub. Yearbook (1952).

A similar trend toward one-paper towns exists in the weekly newspaper field. In 1945, 77 per cent of all weeklies were situated in towns with more than one weekly, Sunvival, of a Free, Competitive Press, Report of Chatrusan of Senate Sanall Business Committee, Sen. Comm. Print No. 17, 80th Cong., 1st Sess. 15 (1947) (hereinafter cited as Survival of a Free, Competitive Press), as compared to 89 per cent in 1951 . The American Press, July, 1951, p. 9.

14. Of cities with two or more daily papers in 1928,87 communities (or 21 per cent) had all dailies under one publisher, Ed. \& Pub., Aug. 18, 1928, p. 3; 161 cities (55 per cent) were in this category in 1945, Nixon, supra note 5 , at 103 ; and 158 (59 per cent) such cities in 1951. ED. \& Pub. Yearboor (1952). These data do not include cities where all papers are under a "partial-combination" plan, with joint control of advertising or printing facilities but autonomy of ownership and editorial policy. There were 13 such cities in 1945, Nixon, supra, at 101, and 15 in 1951. Ev. \& Pub. YeArerook (1952).

Combination ownerships also exist in cities where there are other dailies outside the combination; thus the total number of combinations in 1949 was 196. RAY, CoNCENTRATION of OwNERship and Control IN THE DaILY NEwSPAPER INDUSTRY 4 (1951) (unpublished MS. in Columbia University Library).

15. Multi-paper, one-publisher towns were six per cent of total number of newspaper cities in 1930. Nixon, supra note 5, at 101, 103. In 1951, they were 11 per cent. ED. \& Pud. YEARBOOK (1952).

16. Multi-publisher cities as a percentage of total newspaper cities:

\begin{tabular}{lrrr} 
Year & 1920 & 1942 & 1951 \\
\hline Cities & 549 & 127 & 110 \\
\hline Percent. & $42 \%$ & $9 \%$ & $8 \%$
\end{tabular}

Sources: Fierd, Freedom is More Than A Word 76 (1945); Ed. \& Puw. Yearuodk (1952). 
and account for more than half of national circulation, ${ }^{17}$ a single publisher serves almost half of all cities of more than 100,000 population. ${ }^{18}$ In short, more than 90 per cent of the nation's newspaper communities are one-publisher-or monopoly-towns. ${ }^{19}$ Although the decline in number of dailies has recently abated, ${ }^{20}$ the trend toward local monopoly persists, a trend whose significance increasingly deserves exploration.

\section{Newspaper Monopoly and the Democratic Process}

Analysis of the consequences of local newspaper monopoly proceeds from the fundamental assumption that proper functioning of the democratic process in any community depends upon enlightened discussion and debate. ${ }^{\mathbf{1}}$

17. In 1945 the 17 cities with population greater than 400,000 all had more than one publisher. And two-thirds of cities in the 300,000-400,000 population groups were multipublisher cities. Largely because of these cities, a 1945 analysis showed that newspapers in "competitive" communities enjoyed 60 per cent of circulation. Nixon, sufra note 5, at 108. Moreover, this analysis excluded from the "competitive" category cities with all papers under a partial-combination plan. See note 14 supra. Yet increase of one-daily and one-publisher cities since 1945, notes 13 and 14 supra, probably indicates that even the 60 per cent estimate must be reduced today.

Over time, the greatest decrease in number of dailies has come in the smaller circulation groups, especially in the under-5,000 class. Ed. \& Pub., Jan. 4, 1947, p. 7. Yet in terms of number of ownerships, there is actually a greater replacement rate in some smaller circulation groups than in larger groups. Neurath, supra note 12, at 232.

18. As of 1945, 43 per cent of cities in the 100,000 population group had only one daily newspaper ownership. Nixon, supra note 5 , at 103 . In earlier years the average number of ownerships per city of more than 100,000 population was:

\begin{tabular}{lrrrr} 
Year & 1910 & 1920 & 1930 & 1939 \\
\hline Ownerships & 4.0 & 3.6 & 3.4 & 2.6
\end{tabular}

Source: ERNST, The FIrST FreEDOAI 286 (1946).

19. A "monopoly" city is defined herein as a city with one or more local dailies, all owned by one gublisher. Percentage of monopoly cities to total newspaper cities in past 30 years:

\begin{tabular}{lllll} 
Year & 1920 & 1930 & 1945 & 1951 \\
\hline Cities & $57 \%$ & $79 \%$ & $92 \%$ & $92 \%$
\end{tabular}

Sources: FIEID, FreEDOM is MORE than a WORd 76 (1945); Nixon, supra note 5, at 101 ; ED. \& PUb. YeARBOOK (1952).

Development of local concentration is also apparent in the press of Great Britain. Between 1921 and 1947 a 30 per cent decrease in the total number of "provincial" dailies (those published outside of London) was largely responsible for a 42 per cent increase in provincial one-daily towns. Thus in 1948 of all provincial newspaper-cities, 70 per cent had only one local daily and 88 per cent had only one publisher. RoysL Coxoussio:i o: THE PRess, Report 74, 187-S (1949).

20. In 1951, there was a net gain of four evening papers and a net loss of three morning papers, leaving a net loss of only one daily newspaper. Ed. \& Pub., Feb. 2, 1952, p. 7.

21. See e.g., Militan, Areopagitica (1644) (early campaign for "liberty of unlicensed printing"); MIIIL, ON LIBERTY C. 2 (1859). In the United States, the drafters of the Iïrst Amendment have been considered as aiming to preserve public discussion for its prag- 
This, in turn, is achievable only when the public possesses a realistic mental picture of the world in which it lives ${ }^{22}$ and when citizens hold independent attitudes on issues requiring community decision. ${ }^{23}$ While relative effect on enlightened debate of monopoly and multiplicity in daily newspaper ownership has not yet received thoroughgoing scientific study, ${ }^{24}$ existing research forms a basis for theoretical analysis.

\section{Effects of Nezespapers on Reader Attitudes}

Although the potential of any mass medium to cause complete attitude conversions is probably minimal, media can modify or reinforce audience predispositions. ${ }^{25}$ Newspapers share the ability of other media to influence

matic values as much as for more abstract ends. 2 COOLEY, Constitutional Limitations 886 (8th ed. 1927). See also the classic statement of Learned Hand, J., in United States v. Associated Press, 52 F. Supp. 362, 372 (S.D. N.Y. 1943); and see Holmes, J., dissenting in Abrams v. United States, 250 U.S. 616, 624 (1919); Brandeis, J., concurring in Whitney v. California, 274 U.S. 357, 375 (1927). For brief description of the role of debate and discussion in political life, see Lasswels, Democracy Turougr Punlic OPINION 105-6 (1941).

22. "We shall assume that what each man does is based not on direct and certain knowledge, but on pictures made by himself or given to him. .. . The way in which the world is imagined determines at any particular moment what men will do." LiprMANN, Public Opinion 25 (1930). Thus the formulation of "sound public opinions" depends on citizens' acting "on a realistic picture of the invisible world." Id. at 314. To the press has been handed the role of "stretching the mental world of the individual beyond [the] limit of personal observation and acquaintance." BRUCKER, FREEDOM OF INFORMATION 11 (1949).

23. Discussion and participation in political processes often comes through existence of special-interest or minority groups in the community holding differentiated attitudes. For recent review of role of groups, see Latham, Group Basis of Politics c. 1 (1952). See also note 52 infra.

24. Brucker, Freedom of Information 73-4 (1949). There is in fact a "disappointing scarcity of empirical research bearing directly on the problems of communication effects" in general, although "there is much helpful, though tangential evidence." Schramm, The Effects of Mass Communications: A Review, 26 Jours. Q. 397 (1949). For review of current hypotheses in the field of effect analysis, see ibid.; KLAppER, THE EFrEcrs or MAsS MEDIA (1950).

25. Predispositions, the attitudes prevalent in the audience at the moment it receives a given communication, are shaped by economic, occupational, religious, agc, sex, and social class lines, and also by individual feelings of satisfaction or disaffection within class lines. Kornhauser, Analysis of 'Class' Structure of Contemporary Socicty: Psychological Bases of Class Divisions, in ReAder in Public Opinion and Communication 70, 82 (Berelson \& Janowitz ed. 1950) ; Lasswell, Democracy through Public Opinion 29-31 (1941). Conversion of these predispositions is most feasible under conditions of complete "authoritarian" monopoly over communications facilities, when disparate messages cannot come through mass media. But in the United States a communicator can only approximate such a monopoly position when he advocates attitudes "which already enjoy almost universal sanction." KLApper, The Effects of MASs Media IV-21-22, 57 (1950) ; Berelson, Commmications and Public Opinion, in Reader in Public Opinion and Communicatron, supra, at 448,457 . Under non-monopoly conditions, the effects of mass media will depend on the kind of communication, the medium through which it comes, the issues with which it deals, and the strength of the predispositions it must confront. Id. at 451-7; Schramm, 
attitudes, although the daily press has not retained its once unchallenged leadership as a shaper of community sentiments. ${ }^{20}$ Possible explanations of the press' fall from power are several: radio and television popularity ; ${ }^{27}$ often greater retention or persuasion value of aural communications as compared to print $;^{28}$ relative de-personalization of modern journalism $;^{20}$ alleged failure of newspaper editorials to acknowledge changed economic conditions. 00 Yet newspapers do not go unheeded. ${ }^{31}$ Radio and television focus public attention

supra note 24, at 405-6. In any event, the effect on predispositions is likely to be "reinforcement rather than change, modification rather than conversion." Id. at 405. Yet the long-run effects of mass media may be powerful. For the predispositions which any given communication may reinforce or modify are themselves a product of the cumulative effect of past communications. Schramm, supra, at 405; Berelson, Comminications and Public Opinion, supra, at 459. And these long-run community attitudes may in turn influence what the mass media say, thus creating a reciprocal process which may multiply the effects of mass media. Id. at 450-1; Schramm, sitpro, at 407 .

26. Bogardus, The Makmg of Public Opinion 56-7 (1951). The great majority of dailies, for example, supported Republican Presidential candidates in the last three elections, yet were unable to secure the accord of a majority of the voters. Id. at 57. Yet newspapers contributed to Democratic victories by printing candidates' photos and speeches. And some observers have suggested that Republican candidates might have received fewer votes than they did without overwhelming press support. En:ss \& Lorn, The Prople KNow BEST 46 (1949); MacDougall, The American Press's Infucree on Public Opinion, 3 INT'L. J. of OpInion and AtTrtune Res. 251 (1949).

For examples of the influence of newspapers in past decades, see Snusor, TrE NEwsPAPER AND AUTHORITY C 14 (1923).

27. See Lazarsfeid, Radio and the Prnited Page cc. 4-6 (1940). Surveys indicate that radio has become the preferred or the more utilized source of news for certain population groups: "poor"and "lower middle" class groups in middle-size cities; rural groups; young people; and females in some groups where males still prefer newspapers. See id. at 219; Hearings before Committee on Interstate and Foreigu Commerce, House of Representatives oir H.R. 5497, 77th Cong., 2d Sess. 269-72 (1942); Lrzansfizd \& Stauto:, Ranio Research 1941, 222 (1941). But see note 32 infra.

28. Aural presentation of brief and simple material more effectively elicits retention than does visual presentation, although for complex material, the relative retention of aural and visual presentation probably depends on the educational level of the audience. KIAPPER, The Effects of Mass Media II-26-7 (1950). And as an instrument of persuasion radio communication has been found more effective than print in various field and laboratory studies. See Lazarsfetd, Berelson \& Gauter, The Peofle's Crotce 129 (1944) ; KIAPPER, supra, II-9-10 (1950). For possible explanations, see KEY, PoutTIC,, Parties, and Pressure Groups 596 (1947) ; Lazarsfeld, Rado aito the Printed Page 257 (1940). And see note 31 infra.

29. See Bogardus, The Maning of Public Oprnion 56 (1951). On the decline of "personal journalism," see Watterson, The Personal Equation in Jourialism, in IximespRETations of Jourataisar 141 (Mott \& Casey ed. 1937).

30. Many writers have noted a "big business" orientation of the press. See, e.g., Lerner, The Competition of Ideas, in Ickes, Freedosr of the Press Tonay 181, 183 (1941) ; Statement by John Cowles, quoted in InIon, Public Opmion amb Propagasida 75-6 (1950) ; Szldes, LoRds of the Press (193S).

31. In controlled experiments, researchers have demonstrated that print, and in particular, newspapers, can significantly modify audience attitudes. KLAppen, TnE EFFEcTs of Mass Media IV-2 (1950). Print does have certain unique qualities as an instrument of 
on current events, and newspapers benefit from this sharpened interest. ${ }^{03}$ And even from brief perusal of newspaper headlines, photos, and cartoons, readers receive mental images of local and world events. ${ }^{33}$ Newspaper editorials, because they more often dwell on hometown issues than does "opinion matter" in other media, may exert correspondingly greater influence on local problems. $^{34}$

\section{Monopoly and Newspaper Content}

Ability of a single newspaper to present news with perfect objectivity is severely limited. News, selection and writing are not finite sciences and necessarily invoke value judgments at almost every stage. ${ }^{36}$ Nor can a newspaper,

pedagogy or persuasion: "[It] permits its audience to set their own pace, allows for repeated exposure, allows for treatment of any length." Id. at II-20. And it allows specialized appeals to minority or special-interest groups and may possibly possess greater prestige than other media. Ibid.

32. A 1940 study showed that despite preferences of many groups for radio as a source of news, supra note 27 , proportion of regular readers was greater than proportion of regular radio listeners for every economic and sex group. LAZARSFEzD, RADIO AND THE PRINTED PAGE 224-5 (1940). This apparent inconsistency may partly be explained by the fact that radio news increased interest in newspapers for many in both radio-preference and newspaper-preference groups. Id. at 262.

Television's postwar development has probably not hurt the newspaper industry significantly. Observers have given conflicting answers to the question of TV's effect on newspaper circulation, Ed. \& Pub., Oct. 6, 1951, p. 51. Yet surveys indicate that TV has only slightly decreased newspaper-reading time, while cutting heavily into radio listening. N.Y. Times, Jan. 2, 1952, p. 82, col. 5. One explanation given for newspaper resistance to TV is that " $[\mathrm{T}]$ he newspaper is so tailored to the community . . . that no member . . . can fail to read his newspaper." Ibid.

33. Reportorial content (news) may easily be more effective in modifying or converting predispositions than editorial or interpretive content. Berelson, Communications and Public Opition, supra note 25, at 454. Headlines may provoke their own responses and also affect the responses the ensuing news story produces. Doos, PuBLic OpINION AND Propaganda 440-1 (1948). News photos and editorial cartoons are also powerful stimuli. See id. at 445-8. For statistics on popularity of various kinds of newspaper content, see Schramm \& White, Age, Education, and Economic Status as Factors in Nctespaper Read. ing, in Mass Communications 402 (Schramm ed. 1949); Schramm, The Nahtre of News, id. at 288.

34. See MacDougall, Understanding Public Opinion 604-5 (1952) ; FCC, Puinic SERvice Responsibility of BroadCASt Licensees 40 (1946) (network-originated discussion programs exceed locally-originated discussion programs by 30 to 1). Newspapers may play a major role in determining success of local political party factions. See KEY, Poutries, Parties, and Pressure Groups 594 (1947). Editorial or news "crusades" often succeed in bringing about community reforms, although frequently newspapers have failed to do the job. See Poynter, The Editor's Uneasy Chair, in INTERPRETATION OF Journalism 338, 339-40 (Mott \& Casey ed. 1937).

35. What is the "news angle" of a story in the eyes of one reporter may be expendable trivia to another newsman. See Doob, Pudic Opinion and Propagnnda 434 (1948). When the story reaches the city room, further judgments must be made:

"[A]ny presentation of the news requires some editorial judgment, in the mere selection of what is worth saying-or printing in a paper-out of the immensc 
in preparing either news or editorial matter, base its value judgments completely on the "public interest."36 "Public interest" means different things to different men $; 37$ if it did not, perfect uniformity of opinion would prevail, uniformity which in itself might conflict with the necessity for enlightened discussion. Moreover, a single newspaper cannot fully diversify its news or opinion presentations. Generally only one reporter and one editorial dictum cover a single news development; ${ }^{33}$ space limitations restrict vox pop letter columns; ; $^{39}$ syndicated columnists often do not disagree, and rarely treat local issues. ${ }^{30}$

Although extreme patterns of content uniformity may co-exist with multiple ownership, presentation more diversified than under single ownership is likely.

volume of reports received; still more in the writing of headlines, or the estimate of the relative importance of news as indicated by the length of the story and its position on the page. If it be said that the broadcaster's personal prejudices are likely to enter into his selection or judgment, the same is true of newspaper editors; as can be proved from almost any paper any day. I use the word 'prejudices' there. I mean a man's predilections and opinions."

Testimony of Elmer Davis, Hearings on H.R. 5497, supra note 27, at 255. See also LIPPIrATN, PUBLIC Opinion 354 (1930). For a significant account of the way a telegraph editor makes subjective judgments in selecting one tenth of all incoming wire, service reports, see White, The "Gate Kecper": A Case Study In the Solcction of Ncus, 27 JOURN. Q. 383 (1950).

Nor can even the most careful newspapers maintain perfect accuracy under conditions of high speed and pressure. A check of stories in Afinneapolis papers in 1936 indieated that only 54 per cent of 591 items were asserted to be absolutely accurate by the news sources. Charnley, Preliminary Notes on a Study of Neaspaper Accturacy. 13 Jouns. Q. 394 (1936).

36. For views that monopoly newspapers may enjoy greater economic strength than papers in multi-owner situations; can resist pressures from advertisers or temptation to sensationalize; and thus can provide a paper produced in the "public interest" which serves the entire community well, see statements in 2 ChAfEE, Gorrensrext AND MIASS Conarunicatrons 617 (1947); statement of E. K. Lindley, in Mass Cossusucations 164-5 (Schramm ed. 1949).

37. See Swanson, Midcity Daily: The Neaspaper as it Appeared to Bc, 20 Jourm. Q. 304 (1949), showing disparate views of different community groups on the faimess and lack of bias in news reports of a Midwestern daily.

38. If publisher and editorial writer disagree, it is usually the publisher's editorial view that gets printed. See statement by Gerald Johnson, in Ed \& Pub., Nov. 3, 1951, p. 12; Coxmitssion on Freedoxi of the Press, A Free and Resfonsiele Press 60-1 (1947). Yet there have been instances where the publisher assigned an adjoining column to the opinion of a dissenting editorialist. See, e.g., Ed. \& Pub., Jan. 19, 1952, p. 64.

39. Newspapers receive more letters than they can print. Ed. \& Pub. Jan. 19, 1952, p. 64. Many papers try to print a representative sample. See, c.g., statement of an Indiana editor, in Ed. \& Pub., June 7, 1947, p. 54. Yet if a paper does not choose to print a letter and the writer has no other place to turn, "he must hire a printer, print his brosdside, distribute it at his own expense, and be considered queer." Letter from a New York State editor quoted in Brucker, Freedoas of Informiation 68 (1949).

40. Syndicated columnists may, however, cover especially newsworthy localized happenings, particularly if they occur in a major city. But it is then not a "local issue" in other cities whose dailies print the column. 
Independent dailies may follow identical news and editorial policies. ${ }^{41}$ On the other hand, a monopoly publisher may deliberately purge his pages of all news or editorial matter inconsistent with his own opinions, thus reinforcing the limitations on diversity inherent in singleness of ownership. ${ }^{42}$ Two or more dailies may not provide more objectivity or "public interest" journalism than the single paper. ${ }^{43}$ But separate news reports, headlines, and page make-ups may stress different aspects of current events, and editorial conclusions may differ. ${ }^{44}$ Singleness of publisher control over both dailies, however, generally results in singleness of editorial policy ${ }^{45}$ and may also cause uniformity of news policy and duplication of news reports in both papers. ${ }^{40}$

41. "Likemindedness" of publishers has been studied in published surveys of two communities. In one city editorials and news policies in both papers coincided in several important respects. Bigman, Rivals in Conformity: A Study of Two Competing Dailics, 25 Journ. Q. 127 (1948). And the editorial pages in papers serving the Lynds' Middlletown were both "colorless and noncommital" and Republican. LYND \& LYND, MIDDLETOWN IN TRANSITION 377, 380-1 (1937).

42. See, e.g., 'description of how dailies in Butte, Montana, both owned by the Anaconda Copper Mining Company, covered local strike trouble, in Howard, Butte, City with a "Kick" in It, in OUR FaIR CITY 310-14 (Allen ed. 1947).

43. See note 36 supra. And see, e.g., statement of one prominent editor:

"One of the most competitive cities in the country is Boston, which has not had (at least until very recently) a single daily of general circulation that measures up to anything like the standards of the 'monopolistic' Louisville Courier-Jottrnal or the Minneapolis Star and Tribune. ..."

Seymour, in Mass Comsunications 164 (Schramm ed. 1949).

44. See note 35 supra.

45. In some instances, monopoly publishers have attempted to provide diversity in editorial opinion for their two or more dailies. See, e.g., Ed. \& Pub., Feb. 2, 1952, p. 45 (Republican and Democratic dailies putblished from same plant by single Iowa ownership) ; Ed. \& Pub., Mar. 31, 1951, p. 30 (editorial differentiation between Madison (Wis.) State Journal and Capital-Times, combined under a single ownership). Yet such attempts sometimes break down when the editorial issues are of primary concern to the publisher. For past examples of publisher dictation of news and editorial policy in supposedly autonomous Springfield, Massachusetts, dailies, see Snmon, NEwSPAPER Mortality AND CONCENTRATron 115-7 (1950) (unpublished MS. on file in Department of History and Literature, Harvard University). And in some cities where this has been tried, "the editorials in one of the papers lack sincerity, or can be suspected of lacking sincerity." Statement quoted in Nixon, stipra note 5, at 104.

46. Some monopoly publishers have also tried to encourage newsgathering competition among staffs, and to some extent this may have been successful. Ed. \& Pub., Aug. 27,1949 , p. 8. But see notes 42 and 45 sitpra.

Accuracy may be strengthened by the existence of independently-owned dailies: "Lack of competition often means careless and inaccurate reporting, failure to report all the newsworthy events, and a tendency to 'play safe.' ... But where there is competition, if a reporter overlooks a story, his rival may get it. If he writes inaccurately the opposition sets the public straight. How gleefully they used to do it l" Bird, Nezuspaper Monopoly and Political Independence, 17 Journ. Q. 207, 210 (1940). See also testimony of Robert Lasch, Hearings before Subcommittee No. 2 of the Committee on the Judiciary, House of Representatives, on H.R. 110, 80th Cong., 1st Sess. 46 (1947). This desire to correct the "opposition" may be less strong where in fact there is no "opposition," but only a sister paper with reporters on the same payroll. 


\section{Effect of Content Diversity}

In a monopoly newspaper community, non-diversified presentation of news and editorial matter probably reinforces attitudes of those readers already in accord with policies of the local press. ${ }^{47}$ Vith readers not favorably predisposed, the local press may modify attitudes in the direction pointed to by orientation of news and editorial material. ${ }^{28}$ Thus the monopoly daily or dailies may exert a steady pressure towards uniformity in community sentiments. ${ }^{49}$ But where several independent newspapers serve a city, the reader who buys more than one ${ }^{50}$ will probably acquire a more multi-faceted impression of current history. Conflicting press stimuli may jog his predispositions. And even if citizens buy only that paper whose policies seem most congenial, ${ }^{51}$ the fact of diversity probably ensures that different predispositions of separate community groups receive intensification; and through personal contact with others, each group may gain knowledge of varied community attitudes. ${ }^{52}$ In sum, diversity of newspaper content may provide the community with a more complete "mental picture" of current events and ideas, and encourage independent and differentiated attitudes. ${ }^{.33}$

Multiplicity of daily newspaper ownership seems more likely than monopoly to promote effective working of the democratic process. Other mass media cannot fully supply the diversity in news and editorial content which daily-

47. Reinforcement may be particularly marked where readers are members of a partisan group reading their official journal. Doog, Public Opisiox axd Propagasid 437 (1948).

48. "In one-newspaper communities ... the men and women who disagree with the paper's viewpoint must read its columns anyhow if they are to remain informed concerning local events." Ibid.

49. I.e., by the creation of one "picture" in readers" minds. See note 22 sisfro.

50. Where a community has more than one daily, a large percentoge of families will buy more than one Nixon, Princtples of Advertising 332 (1937). "Overlapping" may be particularly pronounced when the papers are morning and evening.

51. There is little evidence, however, that readers buy a paper because of its editorial policies. Doob, Public Opinion and Propaganda 437 (1948).

52. If each community group, however, receives only reinforcement of its own vicws, the result might be "insulation," and "[t]he unchallenged assumptions of each gruup will continue to harden into prejudice." Comurssion on Freenost or the Press, A Fres niti Responsinle Press 25 (19.7). Yet even if this is the case and if no subsequent crossfertilization occurs through personal contact, a multiplicity of "insulated" prejudices seems preferable to the tendency toward a single orthodoxy in any community.

53. If newspaper multiplicity increases public discussion, the question remains as to the most valuable form such discussion or debate can take. See Lasswer, Derocancy THRotgr Public Opinion c. 7 (1941), suggesting that although the "Hyde Parl Corner" variety of boisterous public controversy performs a valuable "catharsis function," "the Quaker meeting is a more appropriate model for the consideration of grave public questions." Id. at SS-9. Yet even highly emotionalized public discussion or controversy helps to form a "rational public opinion," since "the very process of controversial diseussion forces a certain amount of rational consideration." Blumer, The Mass, the Public, and Public Opinion, in Reader in Public Opmion and Conmunication 43, 49 (Eerelsón \& 
press multiplicity affords.54 Neither weekly newspapers, neighboring city dailies, nor national magazines match the local circulation of the hometown press. $^{55}$ And these media do not provide the extensive day-by-day coverage of local news topics which the local daily supplies. ${ }^{50}$ Radio and television stations, moreover, are often owned or controlled by local newspapers. ${ }^{57}$ And stations' news and discussion programs generally deal in non-local isstes. 58 Thus the community must turn to its daily paper for continuous, locallyoriented flow of news and views. Aware of this fact, some monopoly publishers forego advocacy in editorials on local issues, attempting instead to serve as an impartial judge ${ }^{50}$ or perhaps refraining from any conclusions at

Janowitz ed. 1950). But if some of the "contending views" are withheld from the "disinterested public or suffer from discrimination as to the possibility of being argued before them, correspondingly, there is interference with effective public discussion." Ibid.

54. Existence of these other mass media does, however, prevent the monopoly newspaper from achieving a perfect monopoly over all communications channels. Sec Nixon, The Problem of Nezespaper Monopoly, in Mass Communications 158, 159-60 (Schramm ed. 1949).

55. See, e.g., statistics on circulation in Lorain Journal v. United States, 342 U.S. 143, 146 n. 3 (1951) ; Lynd \& Lynd, Middetown 471-2 (1929). Frequently, howevcr, morning dailies, and particularly Sunday papers, enjoy substantial circulation in ncarby cities. See note 12 supra; circulation data in Newspaper Advertising Rates and Data monthly publications. The estimated pre-issue circulation of all domestic magazines, 140,000,000, ERNST, The First Freedon 116 (1946), is greater than that enjoyed by dailies, yet less than daily newspaper circulation over any given time period.

56. "While a number of metropolitan papers make a show of covering the smaller nearby towns, usually they rely on one man to do the work that requires the effort of from two to half a dozen reporters on the local paper. The ensuing news is seldom, if ever, comprehensive and accurate." Bird, Newspaper Monopoly and Political Independence, 17 JourN. Q. 207, 210 (1940).

57. In 1949, 24 per cent of AM broadcast stations, 39 per cent of FM stations, 47 per cent of TV stations, and both existing facsimile stations were affiliated with daily newspapers. Agee, Cross-Channel Ozenership of Commmnication Media, 26 Jours. Q. 410, 411 (1949). At the same time there were 245 cities where the only newspaper owncd the only one or two radio stations, a large increase over earlier years. Note, 59 YALE L. J. 1342, 1344 n. 9 (1950). Research prepared for an FCC hearing several years ago indicated little difference in number, distribution, or program structure of news programs presented by affiliated and non-affiliated radio stations. Id. at $1345 \mathrm{n}$. 13. Yet single ownership of both media nevertheless presents a possibility of less diversity than when there is separate ownership. However, a monopoly publisher who controls all local radio and also all local weeklies may, if so inclined, manipulate communications concerning local topics to achieve persuasive power which begins to equal that possible under authoritarian control conditions. See note 25 supra.

Facsimile, youngest electronic medium, might provide opportunity for diversity. Yet because "fax" papers may not be so complete as daily papers, they may not perform the same function. Warner, Radio and Television LAW 1119-22 (1948). Moreover, much experimental work in facsimile is being conducted by existing newspapers and their affillated radio stations. Survival of a Free, Conpetitive Press, at 30-1.

58. See FCC, op. cit. supra note 34, at 40; LazArsfeld, RAdio and the Printed PAGE 211-2 (1940); note 34 supra.

59. See Allen, Economic Changes and Editorial Influence, in INTERPRETATIONS or Journalism 419, 430-2 (Mott \& Casey ed. 1937). 
all. Editorial advocacy, however, may catalyze reader participation in community affairs. ${ }^{60}$ But this participation may tend to move in a single direction in a community served by a lone newspaper advocate.

\section{Economics of Daily Newspaper Concentration}

Daily newspapers must seek economic success in two separate yet interdependent markets: reader circulation and advertising space sales. Circulation brings in its own revenues, but it is also essential to attract advertising, which provides the bulk of a daily's income. ${ }^{01}$ While the reader market reacts largely to product quality, ${ }^{62}$ the advertiser market is more sensitive to price. ${ }^{63}$ Thus the publisher must provide facilities for stimulating reader demand and satisfying it with production quantity and speed. And at the same time he must operate at a cost low enough to permit space prices attracting advertising.

\section{Nezesprint 64}

\section{The Circulation Market}

Post-war increases in world-wide newsprint requirements, caused by circulation and advertising advances, ${ }^{65}$ have created special price problems for

60. See note 34 supra. See also Commission on Fresdoss of the Press, op. cit. supra note 1, at 23-4, stating that advocacy is a "proper function" of mass media, which should, however, also publish "significant ideas contrary to their own."

61. Circulation income accounts for approximately 30 per cent of total newspaper revenues. Ed. \& Pub., Apr. 7, 1951, p. 5. The remainder comes from advertising, with only the smallest dailies gaining a significant amount of revenue from "miscellaneous" sources, such as job printing. Newspaper Aupit aNo Resenscr Buresu, Spzctal. Statistical Report (1951) (survey of operations of 11 groups of non-metropolitan dailies for 1950).

62. In the 19th century, however, price competition was frequent and often dramatically effective. See LeE, The Danly Newspaper IN Asrersca 271-3 (1937). In later years there have been sporadic price contests, but consumer demand has reacted to quality rather than price. See FouQueT, Newspaper CoMperition Todiy 36 (1951) (unpublished thesis on file in Economics Department, Harvard University); and see LEE, op. cit. supra, at 274. During World War II prices for most of the industry moved from three to five cents per paper. Borden, Taylor \& Hovde, National Amiertisina ni NewsPAPERS 435 (1946). Though prices in any city or region have tended to rise concurrently, individual price hikes have not cut circulation significantly. FovguEr, op. cil. supra, at 34. Yet trade associations, fearing a ceiling above which price would lose readers, have advised publishers to hold prices to five cents. Id. at 35 .

63. See p. 982 infra, note 205 infra.

64. Newsprint is the variety of wood pulp paper utilized in modern daily papers. It is generally produced from hemlock, fir, and spruce softwoods, H.R. REp. No. 505 , Part I, 82d Cong., 1st Sess. 16 (1951) (bereinafter cited as H.R. REP. No. 505). For all but extremely small-circulating journals, there is no substitute for newsprint in a daily paper. Hearings before Subcommittee on Study of Mossopoly Power of the Comsnillec on the Judiciary, House of Representatives, S1st Cong., 2d Sess., Pt. GA, p. 1127 (1950) (hereinafter cited as MIonopoly Power Hearings.)

65. Since 1945 total newspaper circulation has risen from 48 million to 54 million. ED. \& PUR. YEARBooKs. Advertising volume has increased approximately 60 ger cent, 
domestic newspapers. Producers allocate the bulk of total newsprint production to large and some smaller dailies holding long-term contracts which assure maximum tonnage allowances at prices set by the seller. ${ }^{60}$ Newsprint jobbers, brokers, and paper merchants handle the remaining output, and to this market most small dailies and entering publishers must turn. ${ }^{07}$ Recent uniform increases in producers' contract prices have aroused large publishers, ${ }^{68}$ for whom newsprint occupies a relatively large place in operating

and may be the largest single factor accounting for increased newsprint consumption. Supplies for a Free Press, Report on Newsprint by the Subcommittee on Newsprint of the Senate Serect Committee on Small Business, 82d Cong., 1st Sess. 5-6, 7 (1951) (hereinafter cited as SUPplies FOR A FreE Press). To some extent papcrs have absorbed the additional ad volume by cutting down the percentage of non-advertising space, which for one group of papers fell from 60 to 42 per cent between 1941 and 1947. Friednan, The Newsprint Problen 26 (1948). Yet ad increases have forced rises in page number, from an average of 27 pages in pre-war years to 34 pages in recent years. Monopoly Power Hearings, at 610. An indication of incrcased newsprint requirements is the increase in United States consumption since 1945, when 4,296,000 tons were used, to 1950, when consumption was 5,900,000 tons. SUppliss rok a FkE PrEss, at 22.

66. Few newsprint concerns sell a significant amount of newsprint to buyers without contracts. In some cases contract buyers get almost 100 per cent of production. H.R. Rep. No. 505, at 59, and see Monopoly Power Hearings, Pt. 6-B, at 1155. And the bulk of these contract sales are to large publishers, ibid.; in one war year 3 per cent of the nation's newspapers consumed 55 per cent of newsprint used in domestic dailies. Friedman, The Newsprint Problem (1948) (table 20); and see Supples for a Fret Press, at 5.

Manufacturers requested 3 to 5 year contract periods in the early 1940's, H.R. RE1. No. 505, at 60 , but since the war most producers have insisted on 10-12 year contracts. Id. at 61-2; Montopoly Power Hearings, at 90-91. Contracts once assured the buyer of his "entire requirements," but in recent years have assured maximum tonnage allow* ances instead. H.R. REP. No. 505, at 65-6. Open-price provisions allow the seller to set the prices. See sources cited note 86 infra.

67. Monopoly Power Hearings, Pt. 6-A, at 151. Dailies with circulation greater than 10,000 generally can make carload (25 ton) purchases, but many smaller papers cannot, and thus are unable to contract directly with the mill. Suppules for $A$ FuEt PRESS, at 8. Moreover, even dailies able to buy in carloads find present production is so fully tapped that contracts are generally unavailable. H.R. REp. No. 505, at 9. In some periods, however, some contracts were available; in late 1949 and early 1950 some producers took on new customers. Id. at 7-8. For data on percentage of dailies buying from mills and those buying from wholesalers and jobbers, see NEwSPRINT FOR TONookow, Report and Conclusions of Senate Select Committee on Sinall Business, 82d Cong., 2d Sess. 34 (1952) (hereinafter cited as NEwSPRINT FOR ToMorRow).

68. Per-ton prices of newsprint delivered in New York City since 1945 :

\begin{tabular}{lrrrrrrrr} 
Year & 1945 & 1946 & 1947 & 1948 & 1949 & 1950 & 1951 & 1952 \\
\hline Price in $\$$ & 60 & 72 & 88 & 98 & 100 & 101 & 107 & 116
\end{tabular}

Sources: Supplies for a Free Press, at 22; H.R. Rep. No. 505, at 68; Wall Strcet Journal, Feb. 21, 1952, p. 1, col. 1. The $\$ 116$ price was set in July, 1951. Fortune, Sept., 1951, p. 118.

On May 16, 1952, the Canadian Government approved a $\$ 10$ increase in Canadian newsprint, N.Y. Times, May 17, 1952, p. 20, col. 3, and within one week six leading producers 
budgets. ${ }^{69}$ And the jobber market is often "tight," with open market prices not only exceeding contract prices, but higher than most papers seem willing to pay. ${ }^{70}$

Failure of producers to maximize production from existing mill facilities in early post-war years, ${ }^{71}$ coupled with steadily climbing American newsprint needs, ${ }^{72}$ has caused periods of sharp price rises in the jobber market. ${ }^{73}$

had announced the increase to their United States customers, although one large firm was holding back. Ed. \& Pub., May 24, 1952, pp. 7, 50. The price action was talicn over the vigorous protests of United States publishers, Congressmen, and Office of Price Stabilization. See ibid.; N.Y. Times, May 22, 1952, p. 39, col. 2. Yet neither publishers nor OPS wished to impose ceiling prices, N.Y. Times, Mray 21, 1952, p. 18, col. 1, and "retaliation" suggestions generally "found little support." Ed. \& Pub., May 24, 1952, p. 7. A Canadian Government spokesman explained the increase by the fact that producers' returns had decreased by $\$ 20$ a ton in the past year. Id. at p. 50 . Meanwhile, publishers renewed efforts to reduce newsprint consumption and predicted a round of advertising and subscription rate rises. Id. at p. 7 .

Price increases have generally been uniform for all producers. See note 89 infru. For examples of publisher objection to rising prices, see Mlonoply Pocer Hearings, Pt. 6-B, at 1091, 1096; Ed. \& Pub., Alay 24, 1952, pp. 9-10. Some publishers reirain from blaming producers for rising prices. See, e.g., Monopoly Poarer Hcarings, Pt. 6-A, at 590.

Suspension or consolidation of several large dailies has been attributed to rising newsprint costs. See id. at 1127. For newsprint price history, 1790-1935, see Les, THe DuILy NEWSPAPER IN AMTERTCA 742-5 (1937).

69. Paper and ink as a percentage of total revenues, 1951:

\begin{tabular}{lcccc} 
Circulation (in 1000's): & $10-25$ & $25-50$ & $50-100$ & Ozer 100 \\
\hline Percentage of revenue: & 15.88 & 19.50 & $2 \times .90$ & 38.12
\end{tabular}

Source: Ed. \& Pub., Apr. 12, 1952, p. 74. Ink accounts for only $1-2$ per cent of paper and ink costs.

70. Even in times not considered "tight," non-contract purchasers have generally had to pay open-market price about ten per cent higher than the contract price. Morcover, "[t]he price for less-than-carload lots increases progressively as the size of the purchase diminishes." Department of Justice press release, May 24, 1939, in Monopoly Porter Hearings, Pt. 6-B, at 490 . This extra cost "tends to disappear" in depressiun periods. Ibid.

71. United States newsprint production was at approximately 75 per cent of capacity in 1945, approximately 90 per cent of capacity in 1946. Monopoly Pocuer Hearings, Pt. 6-B, at 43. Canadian newsprint production was approximately 75 per cent of epseity in 1945, approximately 95 per cent of capacity in 1946. Frreresnn, Tue Newspar:T Probleds (1948) (table 10). In following years, however, production in both countries was equal to or in excess of mill capacity. Ibid.; H.R. REP. No. 505 , at 3.

72. See note 65 supro. Wartime government rationing of newsprint, under War Production Board Order L-240, ended in 1946, thus inereasing consumption of large dailies and placing dailies buying on the spot market at a disadvantage. Fnew:sa:t, Tuc Newsprint Problear 31-5 (1948); Survival of a Free, Cosspetiture Press, at 37.

73. In years immediately following the end of the war, spot market prices often went to $\$ 200$ a ton, or three times the contract price. Yet in the middle of 1950 , the sput market price differential was smaller for most papers, Monopoly P(raier Hcarisgls, Pt. $6-\mathrm{A}$, at $151-2$; id., Pt. 6-B, at 37, though some papers were still paying approsimately $\$ 200$ a ton. Ibid. One report, however, stated that mid-1951 spot-market prices "fluurished at reported high of $\$ 300$ a ton." Wall Street Journal, Feb. 21, 1952, p. 1, col. 1. Data in NEwSPRINT For Tosrorsow, at 34 , indicates that in recent months mure large- 
Price levels often rose so high that many dailies found newsprint in fact "unavailable." 74 And few of these dailies could seek full relief from contracting-holding publishers with surplus newsprint ${ }^{75}$ contracts imposed end-use restrictions. ${ }^{76}$ Although the jobber market has recently become "looser," uncertainty remains. ${ }^{77}$ Accordingly, many present and potential publishers ${ }^{78}$

circulation dailies than small were forced to buy print at more than their "regular" price, and for larger dailies this "irregular" price was higher. Yet the "regular" price of small papers, more of whom buy from jobbers, was higher, and there was no indication how frequently any category was forced to buy at "irregular" prices. For non-contract prices in this country of foreign newsprint, see H.R. REP. No. 505, at 90.

74. For contract holders, it is said, the newsprint problem has been one of "price", for smaller dailies, one of "availability". SUPPLIES FOR A FrEE PRESS, 12; Fortune, Sept., 1951, p. 166. When the spot market was "tightest," publishers have complained that "there is no open newsprint market." Survival of a FrEe, Cospetitive Press, at 38.

Failure of dailies to obtain newsprint at prices which they could profitably pay caused exclusion of ads and refusal of new subscriptions, H.R. REP. No. 505, at 11, thus limiting revenues in times of rising costs. Survival of a Free, Competitive Press, at 37 ; sec also Monopoly Pozver Hearings, Pt. 6-B, at 1005. Although industry spokesmen have stated that no daily has suspended "solely for lack of newsprint," id., $\mathrm{Pt}, 6-\mathrm{A}$, at 121, newsprint problems have been responsible in "small" or "large" degree for some suspen" sions. H.R. REp. No. 505, at 10. And see Ed. and Pub., July 28, 1951, p. 7 (allegation that cancellation of newsprint contract alone caused shutdown of a daily).

75. When government rationing ended, the American Newspaper Publishers Associa* tion pledged that no newspaper would be forced to suspend because of newsprint problems; regional publisher associations promised that each daily would be assured of newsprint for eight-page issues. Frtednan, The Newsprint Problem 33 (1948). Controversy exists as to how well this plan has worked out. To charges that the ANPA "sidestepped" urgent calls, quoted id. at 35; Monopoly Pozver Hearings, Pt. 6-B, at 1002-5, the ANPA has replied that large papers performed their missions of mercy. Id. at 1058. A Congressional committee has concurred. See H.R. Rep. No. 505, at 11 , Yet it is probable that publisher cooperation did not ensure some dailies of enough newsprint to permit necessary expansion. See note 74 supra; Nine Nienaan Fellows, Youn Newspaper: Blueprint for a Better Press 19 (Svirsky ed. 1947).

76. "Contracts of important producers frequently provide that the newsprint purchased shall be used only for printing editions of specified publications of the purchaser." H.R. REP. No. 505, at 62 . Such provisions may well inhibit publisher generosity; yet one producer has stated that the purpose of the end-use restrictions was to prevent re-sale at exorbitant prices, "which would lose our good will from all our publisher friends," Monopoly Power Hearings, Pt. 6-A, at 573, and that his company would probably approve publisher requests that they be allowed to help out dailies in trouble. Ibid. However, it was stated that few newspapers have excess newsprint which they can spare. Ibid. For current voluntary newsprint sharing program, see note 285 infra.

77. See note 73 supra, for indications of some easing of price conditions in the spot market in recent years. And at the start of 1952, there appeared to be a temporary "reversal" in the paper and pulp field in general, with larger publisher stocks on hand than at the start of 1951, and monthly consumption down somewhat. N.Y. Times, Dec. 22, 1951, p. 21, col. 8; Wall Street Journal, Feb. 21, 1952, p. 1, col. 1. Yet the paper industry was looking forward optimistically to 1952, N.Y. Times, Jan. 2, 1952, p. 83, col. 2, and predicting record consumption in 1952. Wall Street Journal, Feb. 21, 1952, p. 1 , col. 1 .

78. "When newsprint is in short supply, the spot market all but vanished, and mills 
search for long-term contracts which probably will remain unobtainable until newsprint production capacity expands. ${ }^{79}$

Newsprint industry structure and policies do not encourage creation of additional capacity. Producers of standard (softwoods) newsprint ${ }^{80}$ products fear recurrence of "over-supply" industry conditions which prevailed in the early 1930's, ${ }^{81}$ and are slow to build new mills. ${ }^{82}$ Moreover, potential entrants into the newsprint industry are handicapped by present preemption of the bulk of softwoods timberlands in Canada (which supplies 80 per cent

accepting publishers only on long-term contract basis, as far as newspapers using large tonnages are concerned, the long-term contract is like an economic license to do business." H.R. REP. No. 505, at 61 . Without such a "license," "newcomers cannot get into the field," ibid., although a smaller entrant might be willing to take his chances on the spot market.

79. A small decline in advertising linage is not likely to ease the newsprint situation, since producers can cut production down to 75 per cent of capacity and still malse a profit. Fortune, Sept, 1951, p. 172. Moreover, any decline in U.S. requirements would probably result in rechanneling of more newsprint to other world markets, particularly hard-currency foreign customers. Ibid. Newsprint "famine" has been even more severe in foreign countries, H.R. REP. No. 505, at 4-7. "Estimates of the differential between world production and potential world demand have varied from over 1,000,000 tons to more than 2,000,000 tons." Id. at 6 . Production in all countries outside Canada is below pre-war levels, and idle capacity, caused largely by raw material shortages, equals more than 600,000 tons. Newsprint Assoctation of Canada, Newsprint Data: 1950, quoted in H.R. Rep. No. 505 , at 6 . Prices in foreign markets recently were estimated to be 50 per cont higher than in the United States. Monopoly Pou'er Hearings, Pt. 6-B, at \$47. Many foreign nations, some armed with dollars, seek Canadian output, H.R. REP. No. 505, at 6 , over 90 per cent of which is currently preempted by the U.S. users. SIonopoly Power Hcorings, Pt. 6-B, at 27. In April, 1952, however, a "radical" easing of world supply conditions wis reported, with warnings that the respite might be temporary. N.Y. Times, April 17, 1952, p. 45 , col. 1 .

Yet a severe dip in ad linage, caused perhaps by higher advertising rates, might ease the newsprint problem for United States newspapers. See Fortune, Sept., 1951, p. 169. But publishers have traditionally been slow to raise rates, see note 258 infra, and a heary decrease in linage caused by cyclical conditions would not be welcomed by publishers.

80. See note 64 supra (description of "standard" newsprint products).

81. Monopoly Power Hearings, $\mathrm{Pt}$. 6-B, at 37-S. As a result of large expansion of Canadian capacity in 1925-30, caused by increasing United States consumption, the onset of the Great Depression left Canada with one million tons of idle capacity in the early 1930's and "half of the Canadian industry in bankruptcy." Id. at 32; H.R. ReP. No. 505, at $36-7$.

82. Between 1945 and 1950 capacity of United States mills increased only $\mathbf{5 0 , 0 0 0}$ tons. Monopoly Pozier Hearings, Pt. 6-B, at 43. Between 1946 and 1950, Canadian capacity increased approximately 600,000 tons. Statement by R. M. Fowler, president of Newsprint Association of Canada, id. at 31. Yet no new Canadian newsprint mills were built in this period, ibid., although planning of one new mill started in 1950. Id. at 1005-7. Increased capacity was "achieved partly from the installation of two large machines, but mainly by mechanical improvements and increased speed and efficiency on existing machines." Statement by R. M. Fowler, supra. But neither stretching of capacity nor expansion of production by taxing existing capacity has coped with increased publisher newsprint needs. H.R. REP. No. 505, at 3-4. 
of domestic newsprint) ${ }^{83}$ and in the northwest United States, ${ }^{84}$ although the southern states and Alaska still contain available acreage for newsprint production. ${ }^{85}$ And producer price practices can act as a further deterrent to entry. These mechanisms, including interlocking contracts tying one firm's prices to those of other producers, ${ }^{86}$ and a delivered pricing system based on zone maps, ${ }^{87}$ were initiated in pre-war periods of falling prices as a

83. See note 84 infra. Approximate percentages of United States newsprint derived from domestic production and from Canadian imports have been:

\begin{tabular}{cccccc} 
Year & 1913 & 1923 & 1928 & 1938 & 1950 \\
\hline U.S. & 86 & 53 & 40 & 26 & $\cdot 17$ \\
\hline Can. & 14 & 40 & 54 & 64 & 80
\end{tabular}

Sources: Friedman, The Newsprint Problem 44 (1948) (table 25); Monopoly Power Hearings, Pt. 6-A, at 125. U.S. production dwindled from 1,687,000 tons a year in 1926 to 876,000 in 1948 , id., Pt. $6-\mathrm{B}$, at 43 , while Canadian production increased from $2,068,000$ tons in 1926 to $5,275,000$ tons in 1950. Supplies for a Free Press, at 21-2.

The shift has been explained partly by the natural resources of Canada; by unfavorable United States land policies, Friedman, The Newsprint Prodlem 47-50 (1948) ; by desire of United States newsprint interests to place their operations in Canada beyond the reach of the antitrust laws, Monopoly Power Hearings, Pt. 6-A, at 91; and by the fact that newsprint has been duty-free since 1913. FRIEDMAN, op. cit. supra at 52 . Tariff removal encouraged newsprint industry border-crossing, ibid., and also stimulated production of other varieties of paper products within the United States, Monopoly Power Hearings, Pt. 6-A, at 165, protected by tariffs. For account of publisher activity in removing tariffs see Emery, American Newspaper Purlishers Association c. 6 (1950).

84. Existing firms control large areas either through ownership in fee, under leaschold, or by virtue of cutting rights. H.R. REP. No. 505, at 44. One former Canadian official reported that he could not find "one single undeveloped or unalienated area of Crown timberlands, upon which a newsprint mill could be established." Monopoly Power Hearings, Pt. 6-B, at 1119. For domestic acreage control, see H.R. REP. No. 505, at 45.

85. Entry by non-newsprint paper manufacturers into southern and Alaska timber stands, however, presents the danger that potential newsprint entrants may find these areas largely preempted if they delay action. See Ed. \& Pub., Aug. 11, 1951, p. 34; id., July 7, 1951, p. 30. Moreover, lack of living facilities or a labor market hinders development of an Alaskan newsprint industry. SuPplies for a FreE Press, at 15. The Department of Agriculture has opposed floating of logs from Alaska to mills closer to plentiful labor markets, as this would impede Alaska's industrial development. Ibid. And power costs would make southern production expensive in most localities. Monopoly Povecr Hearings, Pt. 6-A, at 759-60.

86. For examples, see Newsprint Paper Decree Investigation, Report dx Feperal Trade Commission, 1939, in Survival of a Free, Competitive Press, Sen. Coma. PrINT No. 18, 79th Cong., 2d Sess. 56-9 (1947) ; H.R. REP. No. 505, at 76-8.

87. See Newsprint Paper Decree Investigation, op. cit. supra note 86, at 22-3; H.R. REP. No. 505, at 70-76 (describing price effects of zone system). The zone map divides the United States into ten zones, "with a fixed differential from a base price established for each zone." Id. at 70. See copy of map in Monopoly Power Hearings, Pt. 6-13, at 78. Its lines bear "little relation to actual freight rates." NEWSPRINT PAPEN DeCREe Investigation, op. cit. supra, at 22 . Government regulation under the 
"stabilization" measure. 88 Today industry pricing practices yield almost perfect industry-wide price uniformity and have permitted uniform contract price movements. ${ }^{\mathbf{9}}$ While uniform post-war increases multiplied producer profits, ${ }^{30}$ industry members have contended that recent contract price levels were less than the market could bear. ${ }^{91}$ Reluctance to raise prices further may have stemmed from fears of incurring the hostility of government agencies. ${ }^{82}$ But producers through checking their profits may also have wished to deter entry into remaining untapped timberland areas; 93 newsprint manufacture is presently less profitable than other forms of paper production. ${ }^{\text {s }}$. And producers may have aimed to head off development of substitute processes by publishers unwilling to pay prevailing contract prices.

Some larger publishers have sought a steady newsprint supply at steady prices by buying out, investing in, or sponsoring creation of newsprint companies. ${ }^{95}$ Though such publisher-newsprint integration, it is argued,

NRA in 1933-4 and under OPA during World War II encouraged use of the zone map. See id. at 22-3; H.R. REP. No. 505, at 73.

For excellent analysis of delivered pricing systems, see Comment, Price Systcms and Competition, 58 YALE L.J. 426 (1949).

88. Frieduan, The Newsprint Problear 65-6, 6s (1948); H.R. Rer. No. 505, at 127. A House subcommittee has found "indirect evidence of current price agrcements, although it must be stated that this evidence is largely hearsay and much of it has been either contradicted or explained." Id. at 126-7. A trade association supervises activities of Canadian newsprint producers and promotes statistical interchange. Id. at 106-11, $117-8$.

S9. Uniformity evidence summarized, id. at 66-70.

90. See Ed. \& Pub., Mar. 15, 1952, p. 34 (net earnings higher in 1951 than 1950); article in Toronto Star, quoted in Monopoly Ponicr Hcarings, Pt. 6-B, at 1096; Frensan, The Newsprnt Problem $78-87$ (1948) (indicating profits have risen above prewar levels and have exceeded gains of other industries). But see recent claims of decrease in returns, supra note 68 .

91. See testimony of producers summarized at H.R Rep. No. 505, at 87. Existence of higher prices in spot markets, see note 73 supra, further supports the theory that producers could have charged more to contract holders.

92. See H.R. REP. No. 505, at 87-9.

93. See testimony summarized, $i d$. at \&s-90.

94. See Supplies for a Free Press, at 10. Jioreover, "newsprint mills require a greater investment per ton of output than any other paper product ... and, in fact, require an extremely large capital investment in relation to dollar volume of sales compared with almost any other product. ..."Id. at 11. Mforeover, older plants, which represent less capital investment than potential new mills, "can earn a satisfactory return at a price that would not support new ventures." Statement in Newsprist fos Tosronruw, at 117.

95. For list of known publisher newsprint holdings, see Newsprunt Pafer Dectes Investigation, op. cit. supra note 86, at 51-4; Monopoly Pou'cr Hearings, Pt. 6-A, at 214. See description of development of new mills by publishurs who bought up untapped Southern pine timberlands, id. at 757-77. Aside from the two largest United States firms, most domestic newsprint companies "have some financial tie-up with newspaner puhli-hur"," Id. at 215. And 10 per cent of Canadian output, according to one estimate, is "currently 
heightens difficulties for dailies without contracts by fencing off existing output more firmly, ${ }^{96}$ publisher investment in standard softwood newsprint has in some cases augmented total capacity, thus increasing supply for all publishers. $^{97}$ But further expansion through integration may be limited by immense capital requirements, ${ }^{98}$ together with difficulty of locating timberlands both usable and available. 90

Publishers have recently aided development of substitute or variant production methods which, although not all perfected, could permit dailies to control their own supply sources. Newspapers have invested in Texas and Alabama mills using Southern pine timbers, cheaper to purchase but more expensive to pulp than standard softwoods. ${ }^{100}$ And publishers, as well as public and private research agencies, have experimented with fair success on processes using hardwoods chemically pulped, 101 bagasse (sugar cane wastes), ${ }^{102}$ straw, and de-inked old newsprint. ${ }^{103}$ Yet full utilization of new newsprint technologies may await further publisher dissatisfaction with newsprint supply conditions ${ }^{104}$ and producer price policies.

involved in ownership-relations between American publishers and Canadian mills." Friedadan, the Newsprint Problem 40 (1948). In some cases, producers have issued capital stock to publishers in consideration of long-term newsprint contracts. NEwsprinT PAPER Decree InVESTIGATTON, op. cit. supra, at 53-4

96. See H.R. Rep. No. 505, at 13-4; Ray, ANalysis of Some Economic Causes and Consequences of DatLy-Newspaper INTEgration 7 (1951).

97. See H.R. REP. No. 505, at 13. Some publishers have started new newsprint firms, note 95 sipra; others have added new mills to companies they purchased; still others have revived closed-down mills or converted mills producing other paper products to newsprint production. Ed. \& Pub., Jan. 25, 1947, p. 30.

98. See note 94 supra. Small publishers, whose dissatisfaction may be greater than that of large dailies, do not have necessary capital. The smallest papers, it has been reported, do not even have resources to participate in collective establishment of new facilities. Monopoly Power Hearings, Pt. 6-A, at 355. See data on direct relation between extent of integration and circulation size, in NEWSPRINT FOR TOMMORROW, at 34.

99. See notes 84 and 85 supra. Yet there has been some expansion of capacity of publisher-owned firms, encouraged largely by Defense Production Administration granting of certificates of necessity permitting accelerated plant write-offs. Sec Wall St. Journal, Feb. 21, 1952, p. 20, cols. 1-2.

100. Monopoly Power Hearings, Pt. 6-A, at 759; see generally, id. at 757-77 and also note 85 supra.

101. Communication to the Yale Law Journal from H. R. Josephson, Chief, Division of Forest Economics, Forest Service, Department of Agriculture, dated Nor. 27, 1951, on file in Yale Law Library; see also H.R. REP. No. 505, at 18.

103. For description of bagasse processes, see $i d$. at 19-20. A Florida mill is planned to produce 45,000 tons annually at no higher costs than regular newsprint. Ed. \& Pub., Aug. 25, 1951, p. 15.

103. One small, publisher-owned de-inking mill is now in operation. The per-ton cost is $\$ 175$, higher than standard newsprint contract prices, Pulp and Paper, Oct., 1951, p. 35, though the process could profitably produce newsprint at $\$ 100$ a ton. Monopoly Power Hearings, Pt. 6-A, at 901-2.

104. See communication from H. R. Josephson, supra note 101. 


\section{Syndicated features}

The most popular syndicated comics, columns, crosswords, and other "name" features, ${ }^{105}$ effective stimulants of reader demand, ${ }^{100}$ are unavailable to some papers. Syndicates frequently sell features through franchises with "territorial exclusivity" in the buyer's own city and sometimes neighboring towns as well. ${ }^{107}$ When exclusive contracts expire, features may not change hands, for non-franchise holders are often smaller dailies adjoining large metropolitan centers, and are unable to bid features away from prior holders. ${ }^{103}$ Moreover, package selling of features at a flat price may encourage large buyers to purchase unneeded items which then become unavailable to other publishers. ${ }^{109}$ Control of important syndicates by national newspaper chains sometimes results in termination of the non-affiliated daily's contract when the network owner wants to place a feature in his own daily outlet.110 Finally,

105. General features were sold by 145 syndicates in 1951, Ev. \& Pub. Yeurcoon 231-2 (1952), and news-pictures by 84 syndicates in 1951. Id. at 234 (1951). A few syndicates put out dozens of features. In 1946, AP newsfeatures offered 62; King Features (Hearst), 148; NEA Service (Scripps-Howard), 86; United Features (SerippsHoward), 35. SuRvitval of a Free, Cosrpetrtive Press, at 45-47. And in 1952, the Chicago Tribune-New York News Syndicate offered 69. Ev. \& PUB. Yeancoos 3 (1952).

106. Data on percentage of non-advertising space devoted to various content categories in metropolitan dailies from 1910 to 1942 indicate increasing reader desire for syndicated matter, including photos. In this period, space percentage for "comic strips and single" increased $510 \%$; other illustrations, 108\%; amusement features, $45 \%$; "women's interests," $153 \%$. "Columns dealing with public affairs" received no space in 1910, but almost as much space as original editorials in 1940. Computed from data in Mott, Trevds in Neusspaper Content, in MIass Consarunicatrons 337, 339 (Schramm ed. 1949).

107. See Lee, The Dainy Newspaper in Arrenica 600-1 (1937); letter from Stanley Calkins, past president of Pennsylvania Publishers Association, in Suknvas of A FREe, COAIPETITIVe Press, at 44. For indication that area of territorial exclusivity may be larger for some features than for others, see Defendants' Answer, pp. 6-7, Caplin r. United Feature Syndicate, Inc, Civil No. $42-414$ (S.D.N.Y. 1947) (suit by Al Capp for alleged damages incurred through syndicate's methods of selling "Lil Abner"; stipulation of discontinuance executed in 1948. Communication to YaLE LAW Jourral from Sidney A. Diamond, attorney for plaintiff, dated Mar. 11, 1952, on file in Yale Law Library.)

10S. See Lee, The Daily Newspaper in Amrerica 600-1 (1937).

109. For brief discussion of package selling, see Defendants' Answer, pp. 7-8, Caplin v. United Feature Syndicate, Inc., sispra note 107. NEA Service, Inc, offers a "full" package service, as well as "tailored versions" for smaller newspapers. See NEA advertisement, ED. \& PUB. Yearbook 2 (1952). Occasionally a publisher has bought up rights to "dozens of features," printing, however, only a few. Fovnubr, NEwsraper? Conspetimion Today 44 (1951) (unpublished thesis in Department of Economics, Harvard University).

110. The deprived newspaper may have built up substantial readership following on the basis of the feature it loses to a chain. For examples of transfers of features to chain papers connected with syndicates, see Newark Evening News Publishing Co. v. King Features Syndicate, Inc., 7 F.R.D. 645 (D.N.J. 1943) (denial of defendant motion for summary judgment; proposed transfer of "Blondie" and other comics to N.Y. JournalAmerican); Fouguer, op. cit. supra note 109 (transfer of "Hopalong Cassidy" to Chicago and Boston Hearst dailies); Survival or a Fres, Cosspetitrve Press, at 44. 
when syndicates are affiliates of wire services, purchase of a popular feature may be conditioned on subscription to a telegraphic news report. ${ }^{111}$

\section{Wire services}

Even the most thoroughly staffed daily cannot cover widely-scattered world and national news events without the use of one of the major wire servicesAssociated Press, United Press, or International News Service. ${ }^{112}$ Among the services, AP is the publishers' favorite. A cooperative association, ${ }^{113}$ its member-publishers include the great majority of the nation's daily owners. ${ }^{114}$ Under the terms of its present by-laws, compelled by the Supreme Court's 1945 decision in the AP antitrust case, ${ }^{115}$ AP may not refuse membership to applicants on grounds of their potential competition with present members. ${ }^{110}$ In recent years, however, AP has denied membership to some dailies who

111. For one example, see ibid. See also communication to YALE LAW JOURNAl from General Office, Associated Press, dated Feb. 14, 1952, on file in Yale Law Library, indicating that only college, foreign language, and non-domestic newspapers acquire $A P$ photos or features without possessing AP membership.

112. Cf. United States v. Associated Press, 52 F. Supp. 362, 366 (S.D.N.Y. 1943), aff'd, 326 U.S. 1 (1945). An inspection of ED. \& PUB. YEARBOoK (1952) shows that only a few domestic dailies fail to take either AP, UP, or INS reports. There are, however, 46 services presently selling news in this country, many of them providing special-interest reports. Ed. \& Pub. Yearbook 232, 234 (1952). For history of wire services, sce LeE, The Daily Newspaper in America cc. 13, 14 (1937); Rosewater, Histom of Cooperattve NewsGathering in the United States (1930). Increasing reliance on wire services is indicated by the fact that percentage of foreign news and features in sampled metropolitan dailies increased by $155 \%$ between 1910 and 1930 . Computed from data in Mott, op. cit. supra note 106.

113. Domestic general-circulation dailies getting AP service are members or associate members of AP; those who get UP or INS service are subscribers. AP members are under an obligation to supply news to the AP, and they may not furnish "spontaneous" news to any non-member agency or publisher. See Associated Press v. United States, 326 U.S. 1, 8-9 (1945). The by-laws on these requirements have not changed.

114. AP's 1951 domestic newspaper membership was 1,733, Ed. \& Pub., Apr. 12, 1952, p. 9, a figure which includes some dailies twice because of Sunday editions. Communication to Yale Law Journaz from General Office of Associated Press, dated Apr. 14, 1952, on file in Yale Law Library. In 1941-1942, ratio of UP domestic subscribers to AP domestic members was 3 to 4; INS-AP ratio was 1 to 4 . Associated Press v. United States, 326 U.S. 1, 40 (1945) (dissenting opinion).

115. Associated Press v. United States, 326 U.S. 1 (1945), affirming 52 F. Supp. 362 (S.D.N.Y. 1943).

116. Under the new by-law, Art. II (7), passed in 1945, "no member or director shall take into consideration in passing upon such applicant the effect of his or its admission upon the ability of such applicant to compete with members in the same city and field." Ed. \& Pub., Dec. 1, 1945, p. 66. Yet under a literal reading, the members can take into account an applicant's competitive status if he is in the same city but not in the same "field" (morning, evening, or Sunday). The limited wording resulted from the fact that outlawed, old by-laws imposed special restrictions only on applicants in the same city and "field" as an existing member. See District Court decree, $\| 1$, United States v. Associated Press, Civil No. 19-163, S.D.N.Y., Jan. 13, 1944. 
"could not meet the required standards of qualification."117 And AP assessments, which have risen in the post-war period, ${ }^{118}$ are set at the absolute discretion of the Board of Directors. ${ }^{119}$ Moreover, the guiding principle for assessment determination is population size of the daily's locale, ${ }^{100}$ a criterion which ignores page-size or circulation differences among AP members in the same town. But because of the extensive news coverage which AP's cooperative structure provides, few publishers willingly go without AP service, whatever the cost. 121

UP and INS subscriptions are often sold with special bonus guarantees for early buyers. Both services grant many subscribers "asset value" contracts. These guarantee the publisher a special payment which a subsequent competing subscriber must pay in addition to standard service charges. ${ }^{1292}$ Such extra fees for new applicants a few years ago averaged approximately $\$ 25,000$ for UP and $\$ 30,000$ for INS. ${ }^{123}$ Although in most of the very largest cities dailies do not hold "asset value" contracts,"124 elsewhere "asset value" contracts with both UP and INS ensure the sole publisher, frequently a member of AP, a cost advantage over potential competitors. ${ }^{125}$

117. Communication, supra note 111. It is not precisely clear what such standards are, since they are not all specified in the by-laws. Some of the standards considered, however, are existence of a paid subscription list; ability to supply AP with local news; and size of staff and plant. Communication, supra note 114. The Board of Dircetors can elect to Associate Membership, while the annual membership mceting elects to Regular Membership. Communication, supra note 111.

118. Communication, supra note 114.

119. By-laws, Art. VI (3), VII (1), VIII (1) (1945). MIoreover, "[t] he nature and extent of the news service to be furnished to a member shall be determined by the Board of Directors, upon the member's admission. . . By-laws, Art. VII (1), reprinted in Ed. \& Pub., Dec 1, 1945, p. 67.

120. Communication, stpra note 111 .

121. See note 114 supra.

122. Associated Press v. United States, 326 U.S. 1, 13 n.11 (1945); Hcarings bcfore Subcommittee No. 2 of the Committec on the Judiciary on H.R. 110, Suth Cong., 1st Sess., 18-9, 40-1, 55 (1947). In 1944, UP had "asset value" contracts with 215 subscribers in 144 cities, and INS had such contracts with 64 subscribers in 62 cities. Government's Propossd Findings of Fact, Comparison of Proposed Findings of Fact and Conclusions of Law Submitted by the Government and Those Submitted by the Defendants, p. 66, United States v. Associated Press, Civil No. 19-163 (S.D.N.Y. 1944). In addition, 13 INS subscribers held territorially exclusive contracts. Id. at p. 68 . Smaller new services often sell their reports on a territorially exclusive basis. See Hearings on H.R. 110, supra, at 5, 44; United States v. Associated Press, 52 F. Supp. 362, 367 (S.D.N.Y. 1944).

123. Averages compiled from figures, Government's Proposed Findings of Fact, sufro note 122, at p. 66. For description of how asset values are computed, see Hearings on H.R. 110 , supra note 122 , at 18 .

124. In 1944, no morning or evening daily in New York, Washington, Philadelphia, Detroit, Baltimore, Cleveland, St. Louis, or Boston held such contracts with UP; no morning paper in Los Angeles or Chicago; and no evening paper in Pittsburgh. Defendants' Proposed Findings, Comparison of Findings, supra note 122, at p. 68 .

125. In 1944, the only publisher in 26 monopoly newspaper cities had UP and INS asset value contracts plus AP membership. In 18 other cities, the unly morning or evening paper had the same status. Ibid. 


\section{Labor and Equipment}

No daily newspaper can derive maximum efficiency from labor or equipment. Essential speedy newspaper production results in brief clock-time for press utilization. ${ }^{126}$ And since news editors cannot direct a perfectly smooth flow of "copy" to the printshop, type-setting machines and labor often work at less than full speed between pre-deadline peak loads. ${ }^{127}$ Thus publishers must employ men and machines that cannot be utilized to full capacity.

Standard union contract provisions block greater newspaper plant efficiencies. International Typographical Union contracts traditionally call for "bogus": unnecessary reproduction in type of all local ads arriving at the printshop in matrix form. ${ }^{128}$ ITU contracts also require hiring of apprentices who may not assume full printshop duties for six years. ${ }^{129}$ And despite ITU

126. Press-clock-time is almost always under 6 hours, and usually 1 to 3 hours. Malone, Economic-Technological Bases for Newspaper Diversity, 28 JourN. Q. 315,318 (1951). In some cases the period is as low as 50 minutes. Ray, Economic Forces As Factors in Daily Nezuspaper Concentration, 29 JourN. Q. 31, 34 n.18 (1952).

127. See Ray, Analysis of Some Economic Causes and Consequences of DailyNEWSPAPER INTEGRATTON 12 (1951); International Typographical Union, 86 N.L.R.B. 951, 1025 (1949) (Intermediate Report): "Most, but not all, newspapers operate in peaks and valleys." To some extent idle type-setting capacity may be taken up by carcful scheduling of non-"live" news and feature stories throughout the week. And if the daily has a Sunday edition, it can set up and run off certain sections of it during hours when linotypes or presses are not in use. A morning-evening combination ownership permits further maximizing of capacity, for machines can be run around the clock. Sec Fouguet, Newspaper Competition Today 87 (1951) (unpublished thesis in Economics Department, Harvard University).

Dailies must often provide trucks for extra-urban delivery and for delivery to ncwsstands, carriers, and post offices, largely because postal service is not speedy enough. Sec Hearings before the Committee on Post Office and Civil Service on H.R. 2982, 82d Cong,, 1st Sess. 357 (1951). For vehicular statistics, see Census of Manufacrures 1947: Newspapers, Periodicals, Books, and Miscellaneous Publishing 5 (1949). Many of these trucks cannot be utilized continuously.

128. Art. IX, §2, ITU General Laws, provides: "The interchanging . . . or buying of matter, either in the form of types or matrices, between job offices, or between newspaper and job offices ... not owned by the same ... firm ... and published in the same establishment, is unlawful, and shall not be allowed unless such type or matrices are reset as nearly like the original as possible, made up, read and corrected and a proof submitted to the chairman of the office. ..." Another section of the "laws," Art. IX, $\$ 3$ permits exemption of non-local advertising from this requirement, which is normally confined to local ads. International Typographical Union, 86 N.L.R.B. 951, 1025 (1949). ITU claims that "bogus" does not increase costs but only takes up slack production periods. Publishers reply that they could eliminate slack themselves if "bogus" did not exist. Id. at 1027. An NLRB Trial Examiner has concluded that "bogus" is "wasteful," $i d$. at 1029 , and that its elimination would cut newspaper labor needs by 2 to 5 per cent. Id. at 1027. For unsuccessful attempt of publishers to challenge "bogus" as a violation of § 8(b) (6) of the Taft-Hartley Act, see note 280, infra.

129. See ITU General Laws, Art. I, $\S \S 1,13$. The number of apprentices is set by Art. I, $\$ \S 20,21$. Some publishers have complained that ratios allow insufficient replaccment of journeyman printers. See Hearings before Senate Special Committee on Small 
assurances of cooperation in fostering technological progress, 100 the union has often demanded contract provisions guaranteeing its prior consent to composing room innovations. ${ }^{131}$ Steep wage advances for mechanical and editorial employees further reflect organized labor's strength in the newspaper industry. ${ }^{132}$ Current wage levels for newspaper employees, a highly sliilled industrial group, dwarf wages in most manufacturing fields. ${ }^{133}$ Lesser publishers often feel the effects of unions' profitable agreements negotiated with

Business, 80th Cong., 1st Sess. 449 (1947). Yet ITU officials say apprentice quotas are enough to meet "normal operation" needs. Id. at 518-9. For discussion of merits of apprenticeship "laws," see id. at 447-53, 518-34. For discussion of other provisions of ITC General Laws, see $i d$. at 303 et seq.

130. See, e.g., statements, id. at 518.

131. See, e.g., 1949-1950 contract with Champaign, Ill., newspapers. 2 BunEsv of National Affairs, Collective Bargaining Negotuations aidd Contracts, Selcited Contracts IN Text 265. See also, ITU General Laws, Art. III, \$12. ITU domain is principally the composing room, where type is set and pages "made up." Among new technological devises introduced into composing room, see note 138 infra, the most controversial has been the teletypesetter, which operates standard typesetting machines automatically from perforated tapes. ITU wants its members to punch the tapes; dispute over jurisdiction has led to strikes and lockouts. See LeE, The Darly Newspaper i: Arrenues 156-7 (1937); Hearings, supra note 129, at 555-7. Some ITU contracts forbid use of tape supplied by wire services, unless the tape supplier hires union operators, and some locals have refused to handle taped syndicated features entirely. Ed. \& Pub., 1far. \&, 1952.

132. For history of ITU's rise to power, see LeE, The DArLY Newspapes i: Axrerica c. 6 (1937). The three other mechanical unions are International Stercotypars and Electrotypers' Union, the International Photo-Engravers' Union, and the Internstional Printing Pressmen and Assistants' Union. Almost all non-mechanieal workers are under the American Newspaper Guild, founded in 1933 by Heywood Broun. For description of its organizational development, see Exress, Histony of TnE Arrerucas Newspaper Publishers Assoctation c. 15 (1950). See also Associated Press v. NLRB. 301 U.S. 103 (1937) (sanctioning Wagner Act protection for editorial employees aeting on behalf of the Guild).

133. Compared either to production workers in other printing and publishing trades or to workers in all manufacturing of durable or nondurable goods, newspaper mechanical workers in 1950 received higher average weekly earnings for fewer average weetly hours, and thus higher average hour earnings. Compare BUREnu of Linos Statistics, Exiployareant, Hours, and Earnings: Printixg, Publishing, asid Allied Imoustures 3-4 (1951) (mimeo. release), with id. at 1-2, 5-14, and Bureno of LAcos Statisires, Sunzarary of Earnings and Wage Rate Sertes, All Manufacturiac, Durable a:id Nondurable Goods, Selected Periods, 1939-1951 (1951) (mimeo. release). Published figures comparing newspaper mechanical worker wages with those of similarly skilled workers in other fields are not available. The 1939-1950 increase in average hourly wages was less steep for newspaper mechanical workers than for production worliers elsewhere, probably because unionization came later for most industrial than for printshop workers. Conpare ibid., with BuREAU of LABor Statistics, Umon Wages aIs Horrs: PrI:itI:ig INDUSTRY 2 (1950).

Comparison of non-mechanical newspaper wages with those in other fields is more difficult. Earnings of unionized editorial employees are probsbly substantially higher than those of production workers or of office workers in other industries. Comparc Guild Reporter, Feb. 8, 1952, p. 10, with SumsaRy of WAGE RATE Eurinsigs, supro, and 
"leading" dailies ;134 and where city-wide bargaining exists, all papers pay the same wages. ${ }^{135}$

Alarmed by rising production costs and perhaps inspired by scientific advance in other mass media, the newspaper industry has recently attempted to leap out of technological lethargy. ${ }^{\mathbf{1 3 6}}$ In cooperation with allied mechanical industries, publishers have developed printshop processes aimed at labor and materiel savings. ${ }^{137}$ These include "cold" typesetting techniques, which yield not lead type slugs but printed sheets or films, ${ }^{138}$ and improvements on orthodox "hot" type-setting methods. ${ }^{130}$ "Cold" products can be used with either traditional "letterpress" printing presses ${ }^{140}$ or with newer and more

Mohn, Salaries of Office Workers in Large Cities, 67 Monthly LA1. Rev. 240 (1948). Yet editorial employees may be the highest paid category of non-mechanical nowspaper workers; moreover, wages are undoubtedly lower on non-Guild dailies.

For graphical illustration of 1940-1950 wage increases, see infra at p. 995.

134. Wage rates do vary considerably from city to city. See Hearings, supra note 129 , at 550-4 (ITU scales); Guild Reporter, Jan. 25, 1952, p. 7, Feb. 8, 1952, p. 10 (ANG scales). And publishers' claims that profitable agreements with large publishers are "enforced" on smaller ones, SuRvival of A FreE, Competitive Press, at 60, are hotly disputed by unions. See Hearings, stepra note 129, at 546, 549. Yet locals dealing with smaller dailies are undoubtedly bolstered by reports of successful negotiations elsewhere.

135. For examples of city-wide bargaining, see Guild Reporter, Jan. 25, 1952, p. 6 (ANG in San Francisco); Wage Chronology No. 15: New York City Printing, 19301950, 72 Monthly Lab. Rev. 555 (1951) (ITU and Pressmen Union in New York City). Bonus and other ancillary arrangements, however, may differ among participating dailics.

136. "While tremendous strides have been made in press development, there has not been in 35 years any basic change in the method or speed of body type composition, or the productivity per typesetter." Malone, supra note 126, at 322. For one cxplanation of technological lag, see Fortune, Oct., 1949, p. 101.

137. See Emery, History of the American Newspaper Publishers Associntion 215 (1950).

138. Two of these methods involve "photo-composition": one produces copy which is photographed and then reproduced on sensitized offset plates or in engravings; another issues a sheet of film which can be projected directly on the sensitized plates or on photographic paper, thus obviating the photo-copying stage. Another method, involving the Lithotype, types directly on a plate immediately utilizable for off set presses. Earlier models of "cold" machines used typewriter type faces, but many newer models use print typo faces. For description of these processes, see Zeisler, The Revolution in Printing: A Critical Appraisal, 26 Journ. Q. 281 (1949); Fortune, Oct., 1949, p. 101; Ed. \& Pub., Oct. 14, 1950, p. 92; Barnhart, New Processes in Letterpress Printing: "Cold Type" and the Magnesium Plate, 25 JourN. Q. 12 (1948). The potential cost advantage of thesc processes lies in increased per-machine output and in elimination of stereotyping stages. Yet some technical experts suggest that photo-composition methods do not permit flexibility in making corrections and changes, and some doubt that at existing levels of skill operators can match productivity predictions. See Ed. \& Pub., Oct. 14, 1950, p. 92; Zeisler, supra, at 286.

139. The leading improvement is the teletypesetter, supra note 131. According to one estimate, the "TTS" increases output of otherwise standard linotype or intertype machines . from " 50 to $100 \%$ at no increase in cost." Ed. \& Pub., Jan. 12, 1952, p. 57. For history and description of "TTS," see ibid.; Ed. \& Pub., Nov. 10, 1951, p. 49.

140. The Perry Process makes photo-engravings on magnesium plates of photocomposed material. The plates are then curved and placed on the press, without necessity 
economical "offset" presses, which employ chemistry rather than pressure to put ink on paper. ${ }^{141}$ Other innovations streamline dailies' stereotyping and photo-engraving departments. ${ }^{142}$

Full utilization of recent inventions, however, probably awaits demonstration of mechanical speed and dependability of new processes. ${ }^{143}$ Moreover, the established daily, large or small, is reluctant to replace highly-capitalized equipment with costly printshop changes; ${ }^{144}$ retooling may await expiration of a substantial portion of present plant. Finally, fear of union hostility may further delay plant modernization. ${ }^{145}$ Some of the new type-setting methods, in fact, have been used by large dailies only when mechanical workers were out on strike. ${ }^{146}$ And at the strike's end, the journals reverted to traditional printshop operations. ${ }^{147}$ Yet entering publishers, not saddled with heavily capitalized orthodox machinery, may more readily contemplate installation of new machines. New publishers limited in potential circulation by small city population may particularly welcome novel equipment; their small press-

of stereotyping. See Barnhart, supra note 138, at 12-14. Miagnesium plates, also considered for use in standard printing operations, are light enough so that presses built to carry them could run up to twice as fast as present equipment. Ed. \& Pub., Oct. 14, 1950, p. 92.

141. "Offset" presses print from sensitized plates upon which light rays have made emulsive patterns which determine patterns of ink-receptivity. Thus the ofisct process is photographic in nature and forms a natural adjunct to new type-setting techniques also photographic in nature. See Ed. \& Pub., Nov. 4, 1950, p. 26. Yet the "offset" process apparently has "inherent limitations" of speed which prevent its use "by large circulation papers to any great degree." Míalone, supra note 126, at 324. But often more economical than standard rotary press units, see Fortune, Oct., 1949, p. 106, and less demanding in space requirements, these presses may successfully be used by small dailies and weellies.

For other press innovations and new ink formulas, see Zeisler, supra note 13s; Ed. \& Pub., Nov. 4, 1950, p. 26.

142. In addition to attempts to speed up chemical engraving prosesses, Ed. \& Pub, Oct. 14, 1950, p. 92, a new "dry" photo-electric engraving process has emerged which small dailies have used successfully for speedy reproduction of news photos. See communication to Yale Law Jounnal from William M. Simmons, president of The Harvard Crimson, dated Jan. 12, 1952, on file in Yale Law Library. For description of newsprintsaving developments in stereotyping, see Ed. \& Pub., Apr. 14, 1951, p. 53.

143. See Ed. \& Pub., Oct. 14, 1950, p. 92; notes 138, 141 supra. The teletypsetter, however, has apparently "proved" itself and is gaining rapid acceptance. See Ed. \& Pub., Jan. 12, 1952, p. 57.

144. See Ed. \& Pub., Oct. 14, 1950, p. 92.

145. See Hearings, supra note 129, at 441-2; Cosmission on Frezrios of the Press, A Free and Responstble Press 32 (1947).

146. See, e.g., introduction of typewriter keybrard on linotype machines in strusk Springfield, Mass., dailies in 1935, LEE, THE DAmY Newspapes r: Avrenses 157 (1937); use of Varitype photo-composition process in struck Chicago dailies in 1947-1949.

147. Chicago newspapers returned to orthodox "hot" type prucesses when the ITC strike ended. And New York dailies in 1948 hired personnel and trained thcm as varitypists, planning to discharge them "when a settlement was reachud ubviating the [ITU] strike danger." Internationai Typographical Union, St N.L.R.L. 951, 14it n.51 (1949). 
runs make "offset" presses feasible, and relatively infrequent edition changes minimize any inflexibility problems of "photo-composition" typesetting. ${ }^{148}$

The cost structure of daily press operations favors the daily with greater circulation. For an average unit of newspaper production, ${ }^{140}$ some costs are about equal for dailies of all circulation sizes. Newsprint costs per unit are undiminished by higher circulation, ${ }^{150}$ though non-contract holders may pay higher newsprint prices than dailies under contract. ${ }^{\mathbf{1 6 1}}$ Similarly, per unit postal charges may be almost as costly for large-circulation dailies as for smaller papers, ${ }^{152}$ although for all circulation-and-mail department activities,

148. See notes 138, 141 supra; Malone, supra note 126, at 324. But cf. Nixon, The Problem of Newspaper Monopoly, in Mass Comnunications 158, 166 (Schramm ed. 1949): "The 'monopoly' ominibus is here to stay. . . . It is doubtful . . . whether either [cheaper 'cold-type printing'] or facsimile papers will offer any serious competition to the established general-circulation dailies that do a good job of supplying the wide variety of expensive news, opinion, features, and advertising that readers have come to demand."

149. A convenient average unit figure is 1000 or 10,000 8-page papers. (Total number of pages issued yearly $\mathrm{X}$ average daily circulation $=$ total pages in the year. This, divided by 8000 or $80,000=$ total number of 1000 or 10,000 8-page units. This, divided into annual operating costs = average unit cost.) See BORDEN, TAYLOR \& HovDE, Revenues and Expenses of Newspaper Publishers in 1941 22-3 (1946). A similur base, 1000 1-page units, similarly derived, is used for average unit labor costs in graph at p. 1008 infra.

150. Pounds and cost of newsprint used per 10,000 8-page unit in year ending Sept. 30, 1951, for 10 sampled dailies:

\begin{tabular}{lllllllllll} 
Circ. in $1000 ' s$ & 10 & 11 & 13 & 19 & 20 & 25 & 31 & 31 & 75 & 85 \\
\hline Pounds & 1156 & 1090 & 1113 & 1188 & 1103 & 1101 & 1113 & 1178 & 1081 & 1064 \\
\hline Cost in $\$$ & 62.27 & 63.55 & 62.86 & 66.82 & 63.77 & 67.69 & 62.83 & 72.33 & 63.62 & 60.09
\end{tabular}

Source: Data compiled for newspapers' confidential use by Newspaper Audit and Research Bureau, copy on file in Yale Law Library.

Theoretically, poundage discrepancies should be non-existent, but poundage counts or average circulation data may be imperfect. With the exception of one of the 31,000 . circulation papers, the near-uniformity of unit costs indicates that all these dailies held mill contracts assuring most of their needs.

151. See notes 70,73 sipra.

152. Under existing second-class mail rate schedules, daily newspapers are carried to delivery points within the county of publication at no charge, at one cent a copy (for a service most papers cannot use), or at one cent a pound, depending on the service. Charges for delivery outside the county are also based on poundage, with a zonle system stepping up rates for advertising content as delivery distances lengthen. See SEN. ReP. No. 694, 82d Cong., 1st Sess. 12 (1951). With poundage the criterion for most mail rates, two papers mailing out the same percentage of their total units of production would be paying the same average unit cost for postal service, so long as delivery distances and percentage of advertising content were also equal. But specific evidence covering these factors for different classes of dailies is not available. Yet rural papers probably use mails more than urban papers. Hearings before the Senate Committec on Post Office and Civil Service on S. 1046, S. 1335, and S. 1369, 82d Cong., 1st Sess. 243 
unit costs tend to diminish with increased circulation. ${ }^{103}$ Available data do not permit evaluation of relative costs of features and wire services. But average unit labor costs diminish directly with greater circulation. ${ }^{104}$ Editorial, advertising, and composing departments work toward completion of page "forms" for the press. Work in producing "forms" depends not on the volume of copies ultimately printed, but on the number of pages in an individual copy. And although larger-circulation papers generally contain more pages per copy than smaller dailies, page number does not directly rise with circulation. ${ }^{155}$ Greater circulation thus does not add proportionately to the costs of producing the daily's contents. ${ }^{166}$ And because these departmental expenses

(1951). And small papers are less able to use private distribution methods. See id. at 212. However, mailings of metropolitan papers may pay higher zone rates bacause vf wide regional or national distribution. See id. at 253. Moreover, percentage of total space devoted to advertising is probably greater for this class of papers, see Bonozk, Tayzor \& Hovde, Revenues and Expenses of Newspaper Punlisabrs ia 194117 (1946) thus increasing the advertising poundage, to which the zone rates apply.

153. 1950 costs, per average 1000 S-page unit, for circulation-and-mail departments of 95 non-metropolitan dailies in 11 circulation groups:

\begin{tabular}{lrllllllllll} 
Circ. izt $1000^{\circ} s$ & $3-5$ & $5-6$ & $6-8$ & $8-10$ & $10-15$ & $15-20$ & $20-25$ & $20-35$ & $25-40$ & $30-50$ & $45-55$ \\
\hline Cost in $\$$ & 5.28 & 5.12 & 4.95 & 4.84 & 3.96 & 3.60 & 2.92 & 2.96 & 2.44 & 2.91 & 3.48
\end{tabular}

Source: Computed from data in Newspaper Audit and Research Bureau, Specha. Statisticai Repost (1951).

154. See graph at p. 1008 infra. Unit cost data for building and plant or for supplies other than ink and newsprint are not available.

155. Average number of pages per issue in 1941 for the median newspaper in each of six circulation groups representing 74 dailies:

\begin{tabular}{lcccccc} 
Circ. in 1000's & $0-6$ & $6-10$ & $10-20$ & $20-50$ & $50-100$ & 100 pluss \\
\hline Pages & 8.1 & 11.9 & 14.7 & 17.7 & 24.4 & 36.3
\end{tabular}

Source: Borden, Taylor \& Hovde, Revenues and Expenses of Newspafer Pudusyers IN 194117 (1946).

But additional work on each issue is required by the greater edition frequency and wider news and feature coverage of larger dailies. Many afternoon dailies, for instance, attempt to change the front page's face with each new edition. And metropolitan dailies attempt to provide "exclusive" coverage of non-local events, in addition to wire service reports.

156. 1950 unit costs per average 1000 \&-page unit for editorial, advertising and composing departments of 95 non-metropolitan dailies in 11 circulation groups:

\begin{tabular}{l|ccccccccccc} 
Circ. in $1000^{\prime} s$ & $3-5$ & $5-6$ & $6-8$ & $8-10$ & $10-15$ & $15-20$ & $20-25$ & $20-35$ & $25-40$ & $30-50$ & $45-85$ \\
\hline Edit. cost in $\$$ & 14.0 & 10.2 & 10.2 & 8.64 & 7.66 & 6.64 & 5.25 & 5.04 & 5.15 & 4.94 & 4.26 \\
\hline Adv. cost in $\$$ & 10.1 & 5.86 & 6.41 & 5.91 & 4.62 & 4.12 & 3.60 & 2.87 & 3.18 & 2.50 & 1.98 \\
\hline Comp. cost in $\$$ & 19.7 & 14.4 & 14.3 & 9.94 & 8.71 & 7.50 & 6.18 & 6.70 & 6.95 & 6.05 & 3.40
\end{tabular}

Source: Computed from data in Newspaper Audit and Researca Butenu, Special Statistical Report (1951) (for 1950).

Costs in editorial, advertising, and composing departments constitute about $\$ 0$ per cent of total in the lowest circulation group, about 40 per cent in the highest circulation group. Computed from data, ibid. 
constitute a large part of the paper's operating budget, unit costs diminish as circulation size expands: $:^{157}$ large circulation directly produces operating efficiency.

COST PER 1,OOO EIGHT PAGE UNIT FOR 69 NEWSPAPERS, 1941

(MEDIAN FOR GIRCULATION GROUP)

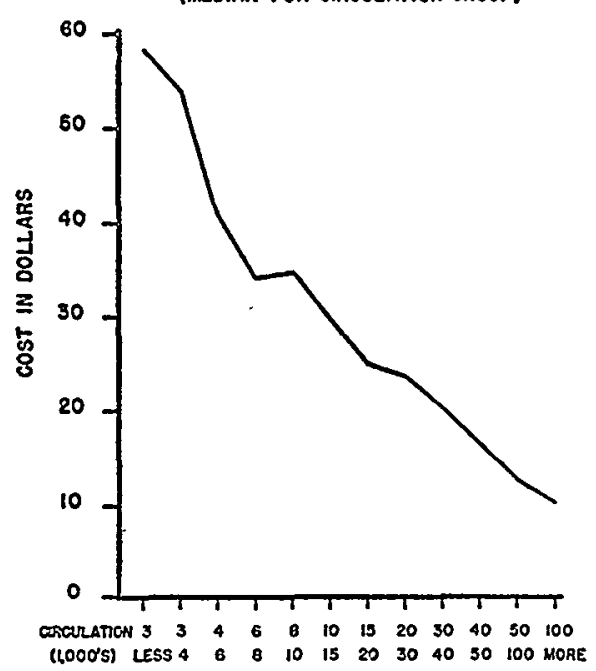

Source: Borden, TAYlor \& Hovde, RevENUES AND EXPENSES OF NEWSPAPER PUBLISHERS IN 194123 (1946).
Although restrictions in newsprint, features, and wire service news may hedge the smaller daily's route to greater circulation, efficiency may come through horizontal combination. Local combination or "partial combination" permits fuller utilization of plant capacity, together with centralized management, research, financing, purchasing, and selling. ${ }^{168}$ Combination in chains, particularly regional networks, brings memberdailies some economies through centralization and specialization, but necessary localization of most newspaper activities severely limits chain efficiencies. ${ }^{160}$ Thus without expanding its circulation, the locally independent smaller daily can do little to improve its efficiency: union rules and the difficulty of introducing sweeping printshop changes may

\section{See graph on this page.}

For other graphical representations of the decreasing costs pattern, illustrating "cngineering cost functions," see Malone, supra note 126, at 320-1. The decreasing curve apparently does not reach a point where increased circulation begets proportional unit expense increases. "At the present ... the scale of operation over which decreasing costs prevail . . . is far beyond the needs of our largest communities." Id. at 322. For variations in unit production costs within each circulation range, see Borden, TAYLon \& Hovde, Revenues and Expenses of Newspaper Publishers in 194123 (1946). But sec Ed. \& Pub., May 17, 1952, p. 65 (statement that "[e]ach newspaper operation is unique" and that cost comparisons thus are not "meaningful").

158. See Ray, Analysis of Some Economic Causes and Consequences of DauyNEWSPAPER INTEGRATION 12-13 (1951). "Reductions in personnel are also accomplished in the mechanical divisions although those economies are less than sometimes supposed." $I d$. at 13. Yet duplication of ads in both papers cuts production costs. Ibid. Moreover, "heavy and expensive newspaper machinery is so well constructed . . . that two papers a day can be printed in the same plant with little increased allowance for depreciations." Nixon, Concentration and Absenteeism in Daily Newspaper Ownership, 22 JouRN. Q. 97, $102-3$ (1945). Similar economic advantages may be derived from the "partial combination" plan described note 14 supra. See Nixon, supra, at 104.

159. See Ray, Analysis of Some Economic Causes and Consequences of DallyNEWSPAPER INTBGRATION 13-14 (1951), describing economy in "intellectual overhead" costs through centralization, and efficiencies caused by "[s]pecialized editorial, advertising, 
foil efforts to lighten the handicaps of small size. And cost rises proportionately higher than in other businesses drive up the unit costs of papers in all circulation brackets. ${ }^{160}$

\section{The Advertising Market}

Because advertising revenues bring in more than two-thirds of total newspaper income, ${ }^{161}$ a daily's economic success depends largely on its ability to sell advertising. Newspapers seek the bulk of their advertising income in two major commercial markets: the retailer market and the "general" advertiser market. ${ }^{162}$ Price of advertising space is quoted in "line" and "milline" rates. The line rate, used for actual billing, merely tells the advertiser how much he pays for each line of space. The milline rate amalgamates a daily's line rate with its circulation. Describing cost per line per million readers, it informs the advertiser of the price he must pay to bring a given quantity of

management, and mechanical personnel whose output and services are shared. ..." Moreover, "[a]ccess of large chains to the capital market facilitates the financing of member units, since the individual newspaper is freed from the influences and obligation associated with sources of local capital." Id. at 14. Yet solicitation of lowal ads, preparation of local news, page make-up, and most mechanical department functions must be carried on locally. The recent relative growth of regional or state-vide chains as compared to national chains, note 5 supra, may indirectly reflect the necessity for lozalization. Cf. Fouguet, Newspaper Cosipetimion Today 94 (1951) (unpublished thesis in Economics Department, Harvard University).

160. For comparison of costs to those in other industries, see note 132 supra (labor); graph at p. 995 infra (labor and newsprint). See also sources cited note 259 infro.

161. See note 61 supra. Publications of "adless" dailies has been rare See, for E. W. Scripps' fairly successful effort, LeE, The DaIry Newspaper in Asresica 18S-189 (1937). A more modern attempt was made by New York's PM, which eventually was forced to carry ads.

"Approximately 50\% of the advertising revenue may be considered to have bren contributed for publishing and profit after the expense attributable to advertising activities has been deducted. ..." Borden, The Econosic Efrects of Auvertising 925 (1942); to maintain newspapers on the same scale minus advertising would require an approximate doubling of circulation revenue. Id. at 926 . Yet ad publication itcelf may ba an important reader inducement; thus most publishers will probably not attempt to omit ads and double price to the reader.

162. General advertisers are usually producers of (or vholesale distributors) of goods. Neither the third major market, that of the "classified" advertisers, nor other specialized classifications are so thoroughly commercial in character. See note 253 infra. Percentage of total income from various ad categories for 1951 :

\begin{tabular}{lccccc} 
Circ. in 1000"s & $10-25$ & $25-40$ & $50-100$ & Over 100 & Composile \\
\hline "Local" & 50.51 & 43.94 & 42.84 & 37.24 & 43.51 \\
\hline "National" & 11.98 & 12.59 & 12.97 & 16.98 & 13.63 \\
\hline "Classified" & 10.82 & 13.34 & 11.87 & 14.60 & 12.66
\end{tabular}

Source: Ed. \& Pub., Apr. 12, 1952, p. 74. "Local" apparently includes retail and other local display categories. "National" is general advertising. 
message space to each potential customer. ${ }^{103}$ Since the lower average unit costs of the larger daily enable it to produce and disseminate ad messages at lower prices, dailies with larger circulation generally offer lower milline

MEDIAN GENERAL MILLINE RATES

FOR EIGHT GIRCULATION GROUPS, 1944

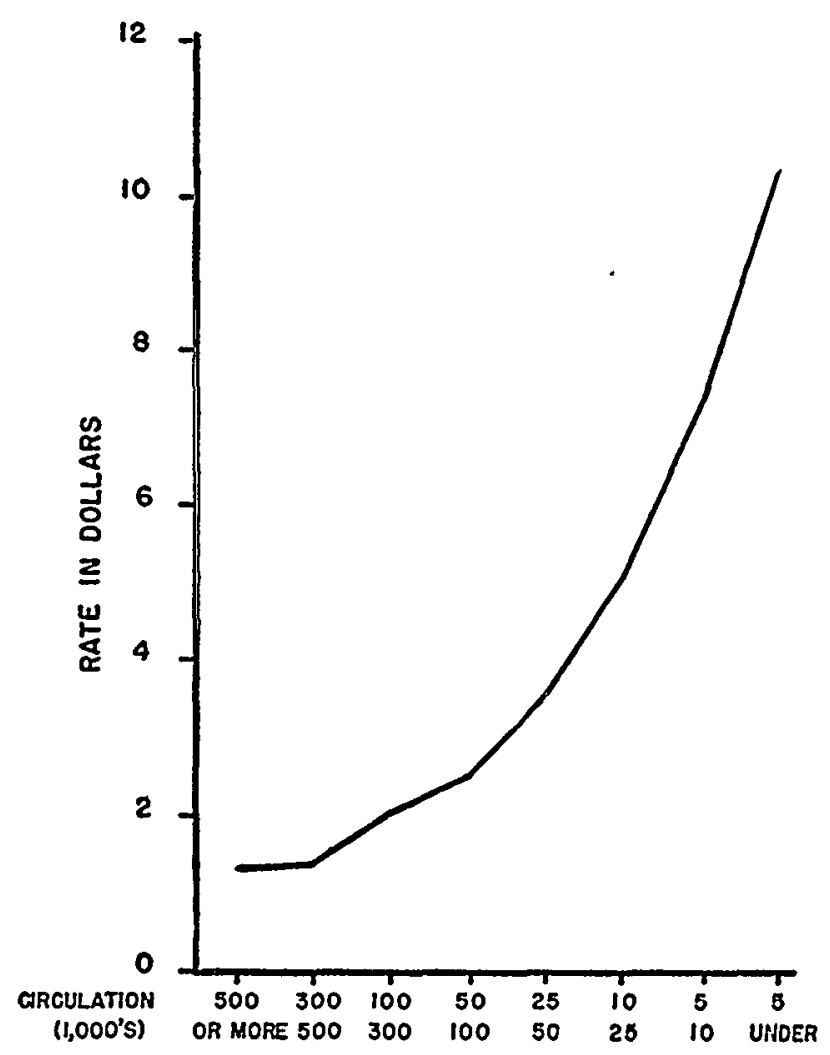

Source: Borden, Taylor \& Hovde, National Advertising in NEWSPAPERS 441 (1946). Rates are "maximilline," or before discount allowances.

rates, though milline rates vary among journals in any one circulation group. ${ }^{164}$

163. For example, a daily with a line rate of 5 cents and circulation of 10,000 has a milline rate of $\$ 5$, while a daily with a line rate of 10 cents and circulation of 25,000 has a milline of $\$ 4$. For more detailed description' of milline computation, see Newspaper Advertising Rates and Data, Dec., 1951, inside back cover. Functions of line and millinc rates are described in NEwSPRINT FOR TONORRow, at 78.

164. For milline-circulation relationships, see graphs on this page and at p. 979, infra. See also graph in Malone, stprce note 126, at 319; table in Ed. \& Pub., 
Publishers exact higher rates from "general" than from retail advertisers. This differential is stretched by refusal of most publishers to allow general advertisers volume and frequency discounts almost always granted to re-

AVERAGE "LOGaL DISPLAY" MULLINE RATE fOR

95 NON-METROPOLITAN DAILLES, 1950

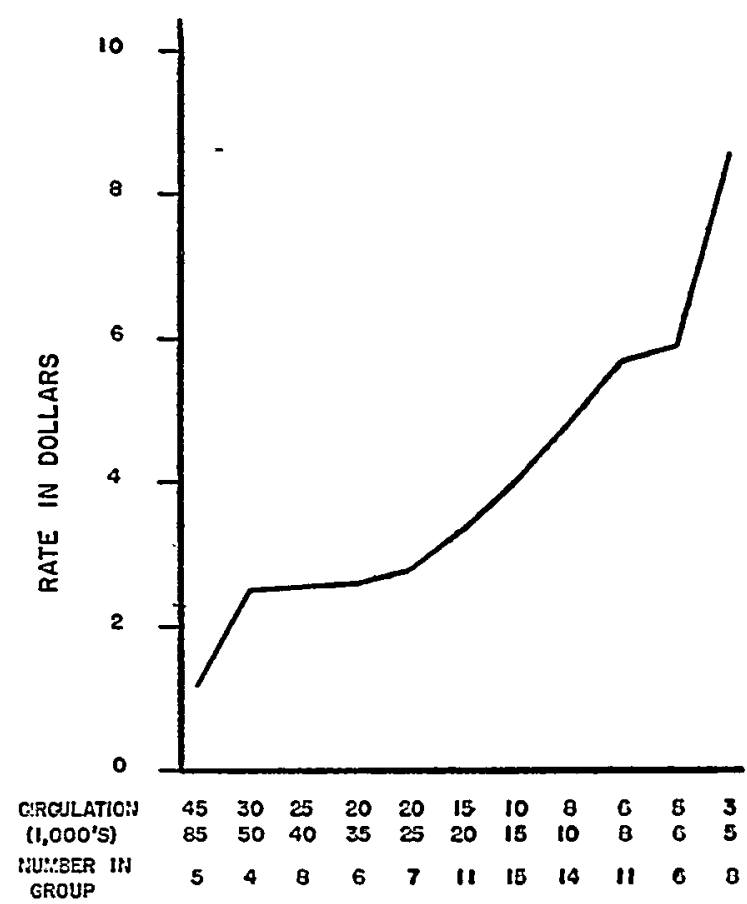

Source: Computed from data in NEwspaper Aunit AND Research Bureau, Special Statistical Refort (1951). "Average" rate = actual revenue received, divided by lines printed. "Local display" includes some non-retail advertising.

Dec. 2, 1950, p. 5. Similarly, millines are lower for cities of higher population. BonIE:3, TAylor \& Hovde, NATIONAl ADVERTISING IN Newspapers 444, 445 (1946).

For milline variations among dailies of like circulation, see data in id. at 441. And sce table of variations for general line rates in Ed. \& Pub., Aug. 25, 1951, p. 11, Nov. 17, 1951, p. 20. Although similar surveys have not been made for retail rates, a sampling of retail rate figures in Axrerican Assoclation of Advertising Agencies, Newsparer Rite DifFERENTIALS, 1950 (1951) indicates significant variations, some of which may be caused by disparate regional rate levels. See chart in Newsprint fur Tosonrow, at 79. Other variations may stem from publisher exploitation of specific market demand cunditions. See pp. $991-7$ infra. 
tailers. ${ }^{165}$ Thus, "general" buyers, largely manufacturers or distributors who advertise branded products, today pay 50 per cent more than retail buyers for 20,000 advertising line purchases in cities of over 100,000 population. ${ }^{100}$ And despite "general" advertisers' demands for its modification, ${ }^{107}$ the rate differential has increased gradually over the past 20 years; retail rates have advanced more slowly than general rates. ${ }^{108}$

\section{The Retail Market}

Retail advertisers typically sell goods in a highly competitive sector of the economy. Because many retailers distribute products largely identical with those sold by rival merchants, competition focuses on price. ${ }^{169}$ Sensitive to cost factors which could hinder competitive pricing, retailers may cut down the volume of ad purchases as the price of advertising rises. ${ }^{170}$ Moreover, the unique advantages of the daily paper, which make it the retailer's favored ad medium, ${ }^{171}$ may depend on space rate cheapnęss. Retailing thrives on heavy and continuous consumer traffic. ${ }^{172}$ Accordingly, mer-

165. When a newspaper's rate card allows volume or frequency discounts, the rate is known as "open"; a "flat" rate provides no discounting. For description of discounting arrangements, see Duffy, Profitable Advertising in Today's Media and Makkitss $79-87$ (1951). Approximately 80 per cent of general rate cards are "flat," but over 90 per cent of retail rates are "open." Borden, TAylor \& Hovde, National Advertising IN NEWSPAPERS 439 (1946).

166. See graph at p. 1009 infra. For most categories of smaller papers, the differential is similar. Estimated 1950 percentage differential in 95 non-metropolitan dailies, based on "average" rates actually paid by advertisers:

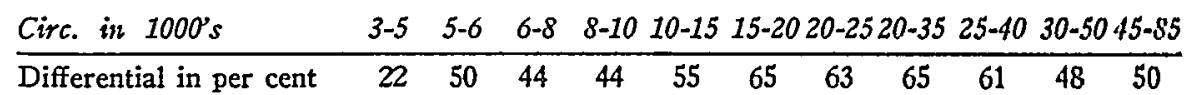

Source: Computed from data in Newspaper Audit and Research Bureau, Special Statisticai Report (1951) ("national" rates adjusted to account for agency commission).

167. See Borden, Tayzor \& Hovde, National Advertising in Newspapers 469 (1946). Advertising agencies also ask for modification. See note 265 infra.

168. See graph at p. 1009 infra. Differential for papers in the category represented in the graph has risen from $37.9 \%$ in 1933 to $55.6 \%$ in 1950 . And the differential in Sunday edition rates has increased from $54.1 \%$ to $68.5 \%$. Data from confidential statistical source.

169. See Wilcox, Competition and MoNopoly IN AMERICAN INdUSTRY 54-9 (TNEC Monograph 21, 1940); Ciark \& Clark, Princtples of Marketing 622-3 (1942).

170. See, e.g., Ed. \& Pub. Feb. 23, 1952, p. 8 (large New York City department store trims linage as result of newspaper rate increases). And sce dramatic linage rise following recent retail cut of two New York dailies. Ed. \& Pub., May 10, 1952, p. 72.

171. In 1950 "local" advertisers (including other than retailers) spent $\$ 1,560$ million in newspaper ads and $\$ 844$ million for advertising in all other media combined. NEwsPRINT FOR TOMORROW, at 101. See also data on distribution of "publicity dollar" of retail dry goods stores, in Borden, The Economic EFfects of AdverTising 914-15 (1942), although these specific figures are probably outdated.

172. See id. at 114-15. 
chants buy frequent quantity display space in dailies for lengthy and fastchanging lists of bargain offers. ${ }^{173}$ Only if retail ad rates are moderate, permitting large linage purchases, can retailers fully exploit the quantity and frequency benefits of newspaper advertising. In fact, retailers dissatisfied with retail ad rates occasionally desert existing local dailies, sponsor Shopping News handouts or rival dailies, ${ }^{174}$ engage in group boycotts, ${ }^{175}$ or turn to radio and television. ${ }^{176}$

Although in each retail market rates and discount schedules are published on rate cards, rate announcements are not always closely followed. Dailies occasionally cut below published rates for large retailers who deal directly with ad salesmen without interposition of advertising agencies. ${ }^{177}$ Other publishers, however, deem it "bad business" to grant preferential rate concessions which appear on the daily's books. Instead, they sometimes print complimentary ads for particular retailers: the books do not register this concession. And many publishers avoid such direct or indirect rate concessions altogether, but may rig rate cards to allow particularly heary discounts for linage volumes which only certain intended retailers can buy. Moreover, only the most confident publisher will raise retail rates before con-

173. See ibid., indicating price orientation of retail ad content. The point is best illustrated by inspection of food, furniture, clothing, and department store display ads of any daily paper. Customers of retailers find "price" the most "helpful" single aspect of retail ads, according to one survey, largely because it enables "comparison." "Illustra-

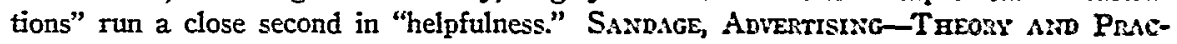
TICE 551-3 (1936).

174. Shopping News fliers, which thrived during the depression, have usually bsen commercially published, though encouraged by advertisers. In other cases, advertisers have themselves published the handouts specifically to force down newspaper rates. See LeE, THe DaIly Newspaper ix Axserica 38s-90 (1937). Newspapers attempted to suppress the handbills by sponsoring municipal anti-handbill legislation. See ibid.; Exsenr, History of the American Newspaper Publishers Assoclation 125 (1950); Inuo:, Public Opinion and Propaganda 107-11 (1950). For description of advertisers" sponsorship of a general circulation daily because "they did not like" presence of local daily" monopoly, see LEE, op. cit. supra, at 372.

175. Twelve stores boycotted the New York World-Telegram in 1932 and succeeded in modifying a proposed rate rise. LEE, THE DArLY NEWSPAPER IN AxreRren 372-3 (1937). And for sketch of boycotts in New Haven and Pittsburgh, see id. at 372. In 1943 , fifteen New York department stores and their trade association were fined $\$ 5,000$ each after pleading nolo contendere to an information filed by the Department of Justice charging violation of the antitrust laws in an attempted conspiracy to boycott the New York Times because of hostility to an announced increase in ad rates. 11 U.S.L. WEEK 2739 (S.D.N.Y. 1943).

176. Cf. Ray, Contpetition in the Newspaper Industry $15 \mathrm{~J}$. MSArswr1:a 444, 445 (1951). See p. 992, infra. For analysis of retailer radio usage, see SAsd.age, Rnoro ADVERTISING FOR RETAILERS (1945).

177. "Most retail advertising is prepared by the advertising department of the retail store, and ordered directly from the newspapers." DuFFY, op. cit. supra note 165 , at $\$ 4$. See note 178 infra. 
sulting dominant retailers to gain their counsel and estimate their future response. ${ }^{178}$

Where two or more dailies serve a single community, the paper offering lower milline rates generally secures greater retail display linage. ${ }^{170}$ Retailers, however, often prefer to advertise in an evening daily; its circulation is frequently heavier in shopping districts and may have greater "pull" among housewives responsible for most retail purchases. ${ }^{180}$ Thus an evening paper competing with a morning paper frequently sells more advertising, though charging a higher milline rate. ${ }^{181}$

\section{The General Market}

Advertisers in the general market are mainly manufacturers of consumers' goods. ${ }^{182}$ Since such producers tend to compete in product quality rather than price appeal, ${ }^{183}$ their advertising campaigns stress quality and performance,

178. Information of publisher concessions to retailers comes from interviews with confidential sources. Some of these practices, however, may conflict with the Code of Practice of the Newspaper Advertising Executives Association: "2. Rates and conditions published in the rate card will apply to all advertisers.” ED. \& PUв. YEARUOOK 296 (1952).

179. An inspection of 1950 retail milline rates and linage of dailies in 26 cities of greater than 100,000 population and with two or more dailies, none of which are sold in "forced combination," see note 217 infra, shows that in 17 cities the lowest-milline daily secured the greatest retail linage. In 8 out of the 9 remaining citics, top linage went to the evening papers, despite the fact that its rate was not the lowest. In another analysis, the 26 cities were broken down into morning and evening fields. Thirteen fields had two or more dailies, and in 9 of these, the lower-milline daily received the greatest linage. Rate data from American Assoctation of Advertising Agencies, Newspiples Rate: Differentials, 1950 (1951); linage data from Ed. \& Pub., Mar. 10, 1951, pp. 75-90. Data for similar analysis of papers in smaller-population cities is unavailable.

180. See Ray, Economic Forces as Factors in Daily Newspaper Conccntration, 29 JouRN. Q. 37-8 (1952), indicating that advertiser preference for evening dailies is prevalent principally in small and medium-sized industrial cities. See also note 12 supra.

181. See note 179 supra.

182. Data in Borden, Taylor \& Hovde, National Advertising in Newspalens $38-40$ (1946) show that "industrial products" ads brought in only $3.4 \%$ of newspaper" revenues from national advertising in 1941. In times of the excess profits tax, nonconsumers' goods producers may be tempted to indulge in more newspaper advertising of a political or institutional nature. See, e.g., announcement of the Advertisers for Freedom Committee, in Ed. \& Pub., Jan. 26, 1952, p. 56.

183. "Imperfect" or "monopolistic" competition, where product differentiation supplements or supplants price competition, is a common feature of markets for manufactured consumers' goods. See Wucox, op. cit. stipra note 169, at 3-4. And "competition" is generally less prevalent in manufacturing categories than in retail categories of business activity. Id. at 307-8.

Specifically, among advertising maufacturers, price competition is not prevalent. Sce Brown, Advertising and The Public Interest: Legal Protection of Trade Symbols, 57 YALE L. J. 1165, 1173 (1948). "[T] he histories of a host of consumers' goods . . . are proof that it does pay to advertise, that it pays in higher prices and higher profits than if the product was in undifferentiated competition with like products in a competitive market." Id. at 1174-5. 
educating consumers to appreciate brand names and to regard price cutters with suspicion. ${ }^{184}$ In this market context, non-price considerations, rather than rates of advertising media, determine an advertiser's total ad expenditures in newspapers. ${ }^{1 \mathrm{s5}}$

"General" advertisers leave campaign list-mahing and many other decisions to the discretion of advertising agencies, who also recommend general budget strategy to their advertiser clients. It is the agency, not the advertiser, with whom dailies deal, and to whom publishers sell space and send bills.. ${ }^{180}$ Agencies have little incentive to seek cheap rates for general advertising space. Three quarters of advertising agency revenues consists of commissions granted by advertising media. ${ }^{187}$ The commissions are based on a flat percentage of dollar "billings" placed by the agency; in the case of newspapers this rebate is 15 per cent. ${ }^{188}$ Hence, agency compensation depends not on quantity of space purchased but on size of clients' ad expenditures. ${ }^{159}$ And since total ad

184. "[A]dvertisers generally make their appeal to buying motives other than price." BoRden, ThE ECONOMIC EFFeCTs of Advertising S64 (1942) (referring to manuiactureradvertisers). The "main drive of advertising is to facilitate" product differentiation "in order to carve out a separate market in which demand, price, and output can be manigulated within limits..." Brown, stspra note 183, at 1171. For discussion of manufacturers" product branding and the "struggle for brand control," see Bopnes, op. cil. sifra at 34-46; Ciark \& Clark, Princtples of Mlarketing, 255-66 (1942).

185. Cf. Ray, Competition in the Newspafer Industry, 15 J. MLsRnerrac 444, 447 (1951), indicating publishers' estimates of the relative inclasticity of demand on the part of general advertisers.

Interviews with advertisers and agencies, however, indicated that wide variance in milline rates among papers of similar circulation, see note 164 supra, is considered "illogical" and operates against the use of newspapers as a basic ad medium. Benos:. Taylor \& Hovne, National Advertising in Newspapers 453, 458-9 (1940). Similarly, the general-retail differential, failure to give general advertisers discounts, use of forced combination rates, see note 217 infra, and the decline of radio and magazine per-unit rates have reduced buyers' enthusiasm for newspapers. Id. at 448-9, 469-70. Yet "more important in the minds of advertisers than questions of relative costs of cuscrage . . . are considerations relating to the sales effectiveness of any medium." Id. at 452. The apparent sales effectiveness of competing media (principally radio) directly accuunted fur almost all of a $22.6 \%$ decline, from 1929 to 1941, in newspapers" "share" of total national advertising expenditures. $I d$. at 38 .

But cf. note 257 stipra.

186. Axterican Assactation of Adiertising Agenctes, The Structure of the Advertisixg Agexcy Business 11-13 (1951). For brief history of agency functions, see

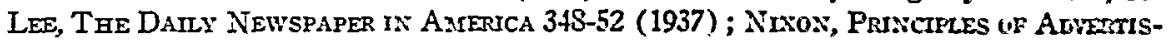
ING 18-19 (1937).

187. The other quarter comes directly from advertiser clients, in the form of service charges added to cost of materials and service purchased by agencies for campaign purposes, and fees for special services. See Auericin Associntron of Abrestistivg Agencies, The Structure of the Advertising Agency Business 14 (1951).

18s. Radio and magazines generally allow the same commission. See Derry, of. cit. supra note 165, at 323-5 for detailed description of the commission system.

189. Criticized by advertisers, this payment method is said to resemble "Bernard Shaw's judge-hangman whose fees depended upon the number of exccutions." SAro.rge, Advertising-Theory and Practice 516 (1936). Agencies, advertisers and media have 
budgets of general advertisers are not primarily influenced by media rate levels, ${ }^{100}$ cheaper rates do not bring larger agency returns. Moreover, promotional skill, integrity, reputation, and financial soundness, rather than promises of bargain rates, are decisive factors in inter-agency rivalry. ${ }^{101} \mathrm{Ad}$ agencies, in fact, are not really "agents" of the advertiser, but independent enterprisers whose interests lie partially with publishers, who disburse most agency revenues. ${ }^{102}$

Agency campaign lists are largely impervious to rate concessions. ${ }^{103}$ Open pricing is the rule in the general market. Current rates and announcement of future changes appear monthly in a widely circulated trade rate book, which also presents milline computations. ${ }^{104}$ Deviations from announced "general" rates are probably rare; publishers in contracts undertake to follow a uniform non-discriminatory rate policy toward all agencies. ${ }^{105}$ And agencies

debated the commission system for years, and in the 1930's exchanged books on the subject. See Young, Advertising Agency Conpensation (1933) (defense of commission system on behalf of the A.A.A.A.); HaAse, Advertising Agency Compensation: THEORY-LAW-PRACTICE (1934) (answer by the Association of National Advertisers); Adrerican Association of Advertising Agencies, Analysis and Cruticism of "Advertising Agency Compensation: Theory-Law-Practice" (1935) (rejoinder). See note 202 infra for FTC attack on commission system.

190. Sandage, Advertising-Theory and Practice 555-68 (1936) lists factors determining budget size.

191. See Lee, The Daily Newspaper in America 352 (1937) ; Amerrcan Associntion of Advertising Agencies, The Structure of the Advertising Agency Businlss 13-14, 18-25 (1951) (including A.A.A.A. Standards of Practice); SANDAGE, AdverresING-THEORY AND PRACTICE 530-2 (1936).

192. Originally agencies were publishers' agents, selling space on commission, or space "brokers." Some agents and brokers later became "special representatives" selling space in specific dailies, while others became advertisers' "servants," precursors of modern ad agencies. See Nixon, Principles of Advertising 18-19 (1937); LeE, Tue Dally NEWSPAPER IN ANERICA 348-52 (1937); Young, op. cit. supra note 189, at 21-38.

On one hand the agency poses as the servant of its "client," the advertiser, and advertisers sometimes consider the agency "a working partner." See SANDAGE, Adviktising-Theory and Practice 515-6 (1936); Gamble, Organization and Function of the Advertising Agency 24, 32-3 (1949). Yet the A.A.A.A. has asserted that agencies are publishers' agents. SANDAGE, op. cit supra, at 515. The ad agency system of compensation also suggests this relationship.

193. See, e.g., failure of St. Louis Post-Dispatch to draw significant added linage from general rate reduction. Borden, TAYLOR \& Hovde, National Advertising in NewS'יirers 439-40 (1946).

Agencies, in fact, usually resist and resent any attempt of a newspaper, through various forms of "undue pressure," to "break" (gain a place on) a previously-cstablished campaign list. And advertisers are often irritated by dailies who request them to order agencies to revise lists. See id. at 207, 209, 210-12.

194. The rate book is Newspaper Advertising Rates and Data, published monthly by Standard Rate and Data Service. Each newspaper also sends its general rate card to agencies.

195. This provision is written into A.A.A.A. Standard Order Blanks, GAMuLE, $o p$. cit. supra note 192, at 27 , which are used by most agencies. Durry, op. cit. supra note 165 , at 330 . 
rarely attempt to bargain for special reductions from announced rate schedules or for modification of rate cards;138 agents fear that "responsible publishers" will not tolerate aggressive bargaining tactics. ${ }^{107}$ 'The agencies' industry-wide code of ethics, moreover, forbids agencies to rebate their commissions to clients, a practice branded as degrading the rate structures of publishers. ${ }^{103}$

Publishers, in turn, grant commissions on general advertising sales only to agencies which they "recognize,"199 and "recognition" hinges partly on agency adherence to the no-rebate rule of the industry code. ${ }^{-30}$ Other standard recognition criteria are agencies' financial "capacity," and "bona fide" agency status demanding freedom from control by advertisers. ${ }^{01}$ Thus both advertisers performing full agency functions and "house" agencies of large manufacturers are denied recognition and commissions. In effect, functional compensation is withheld from all but "bona fide" agencies; direct buyers of general linage receive no discount for their efforts. ${ }^{202}$ Space buying

196. See communications to the YaLE LAw Jounmal from Atherton W. Hobler, Chairman of the Board, Benton and Bowles, Inc, dated Apr. 8, 1952; from the Duane Jones Co., Inc., dated Apr. \&, 1952; from a leading agency (name withheld by request), dated Apr. 14, 1952, all on file in Yale Law Library. Occasionally, however, agencies bargain "as to how an account should be classified where several general rates prevail. ..." Communication from Atherton W. Hobler, supra. And space buyers often try to "hold a rate on a schedule approved or contemplated by a client-before the new raise in rate was announced" and wish to "get in' on old rates before new ones go into effect. ..." Communication to the Yale LAw Jouraras from president of a leading agency (name withheld by request), dated Apr. 11, 1952, on file in Yale Law Library.

197. See communications from Atherton W. Hobler and the Duane Jones Co., Ine., supra note 196.

198. Standard of Ethics, reprinted in Arrerican Associntion of Adrertisizic Agesicies, The Structure of the Adtertising Agency Business 21-4 (1951). Agencies" refusal to rebate "maintain[s] . . . rate cards" of media ouners. GasonLe, op. cii. subpra note 192 , at 26 .

199. For brief description, see Amersican Assocution of Advertisisic Agesicies, Advertising Agency Recognition (undated mimeo.). Publishers' associations male recommendations to individual owners, who make the final decisions. Id. at 1.

200. Id. at 2 .

201. Ibid.

202. GAXrBLE, op. cit. supra note 192, at 24 , summarizes specific reasons given by media owners for favoring the existence of independent ad agencies. These include development of "new business"; reduction of "the hazards of advertising and thereby the mortality rate in the publisher's business"; advocacy of "the idea of advertising in competition with other means of sales promotion." But see also p. 994 infra.

In 1924 the FTC issued a complaint, amended in 1926, against the A.A.A.A.; the American Press Association (a "boiler-plate" firm); the American and Southern Newspaper Publishers Associations; and the Six-Point League (national advertising representatives of New York dailies). It charged respondents with attempting to compel national advertisers to hire agencies; prevent advertisers from placing ads at the "net rate" (minus agency discount); and eliminate agencies sharing commissions with their clients. In sum, respondents were charged with "combining or conspiring to control channels of distribution of national advertising." See American Association of Advertising Agencies, 13 F.T.C. 326 (1930). In 1930, however, after answer and trial, the complaint was dismissed without assignment of reasons. Ibid. 
is thus channeled to independent agencies, where price haggling is kept to a minimum.

In general, dailies offering lower milline rates usually secure greater linage than higher-milline papers in the same or other cities. ${ }^{203}$ Agency space buyers often set milline ceilings within each newspaper circulation group to exclude exceptionally "high-rate" dailies from consideration. ${ }^{204}$ And even

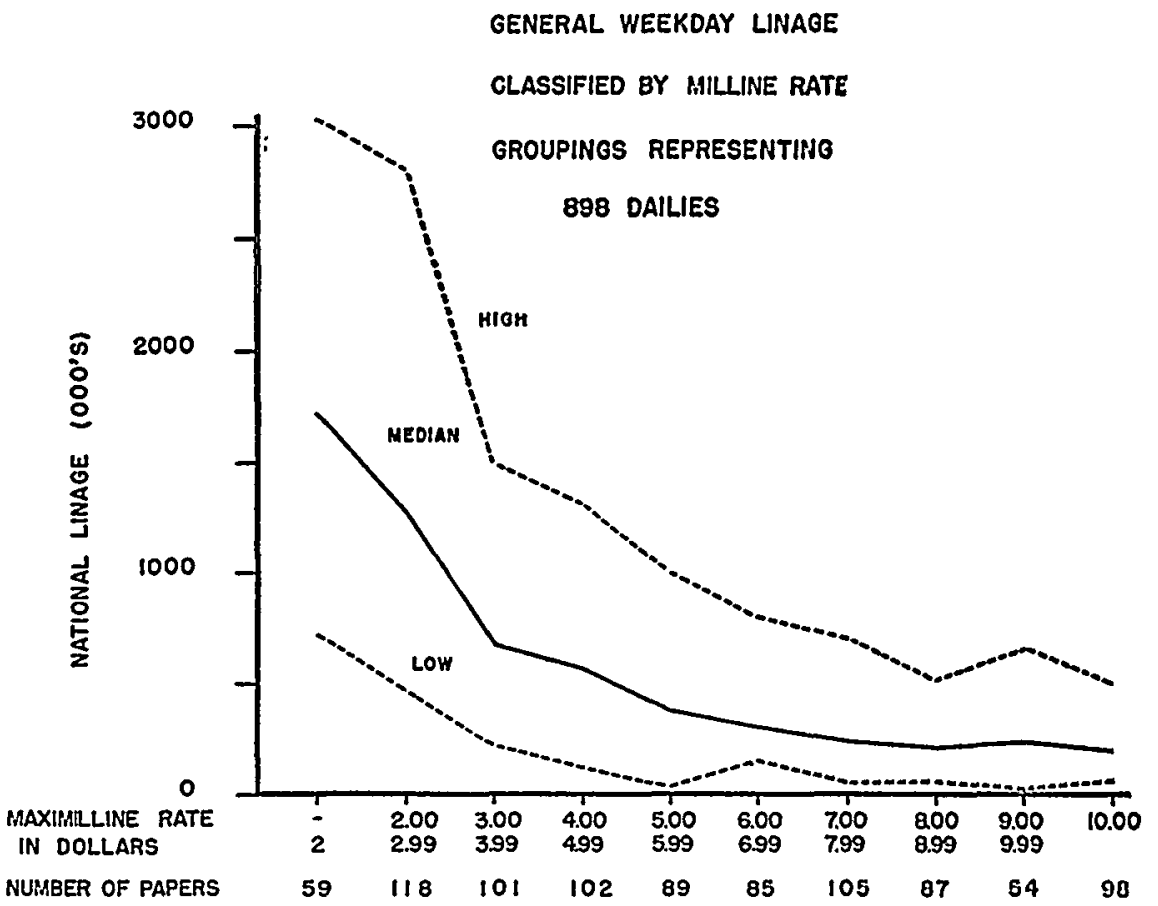

Source: Borden, Taylor \& Hovde, National Advertising in Neivspapers 454 (1946). Figures are for 1941 .

203. For milline rate-linage relationships among dailies in different cities, see graph on this page; tables in Borden, Taylor \& Hovde, National Advertising IN NewspAPERS 454, 456, 457 (1946). An inspection of 1950 general milline rates and linages of dailies in 34 cities of greater than 50,000 population and with two or more dailies, none of which are sold in "forced combination," shows that in 18 cities the lowest-milline daily secured the greatest general linage. In 15 out of the 16 remaining cities, top linage went to the evening daily, despite the fact that its rate was not the lowest. In another analysis, the 34 cities were broken down into morning and evening fields. Thirteen fields had two or more dailies, and in 10 of these, the lower milline daily received the greatest linage. Linage data from Ed. \& Pub., May 10, 1951, pp. 75-90; rate data from AxkeucsN Association of Advertistng Agenctes, Newspaper RAte Differentials, 1950 (1951); Newspaper Advertising Rates and Data, Dec. 1951 (comparative recency of data in this source is not believed to affect validity of rate-linage comparisons).

204. See Borden, Taylor \& Hovde, National Advertising in Newsparers 454-5 (1946). 
within ceiling limits, lower-milline papers sell greater linage. But these are higher-circulation dailies, and their greater circulation coverage rather than the cheaper milline rate may influence advertising agencies' decisions. ${ }^{205}$ Schedules for advertising campaigns are based on specific market coverage goals, with rate criteria often secondary. ${ }^{20 B}$ In fact, despite higher millines, smallcirculation dailies often find a place on schedules for nationally extensive or regionally intensive campaigns. ${ }^{207}$ Their linage allocations, however, usually will be smaller than those of greater-circulation papers. ${ }^{203}$ And newly established dailies find listing even harder. Few advertisers wish to "pioneer" in new dailies, and data on the buying habits of entrant's audience is frequently absent; moreover, a new paper's poor initial linage record in the retail market may also discourage potential "general" buyers."00

\section{Sales Factors in Retail and Gencral Markcts}

Dealer Cooperative Advertising. A practice partly inspired by the generalretail differential, dealer cooperative advertising bridges the gap between the two markets. Cooperative advertising takes many forms. 210 Under a common arrangement, manufacturers grant advertising allowances to retailers for

205. "Rate is only one of many factors which have to be considered in the selection of media." DuFFy, op. cit. supra note 165, at 323. See also id. at 82. For list of other factors, see id. at 62-3, showing importance of various criteria other than rates in determining manufacturers' preferences among dailies; similar ranlings are not available for agencies, however. Rate considerations are, however, influential, not only as a measure of cheapness of space in different-sized dailies, but also as a criterion for selecting among newspapers of equal circulation when the campaign males choice possible. Butrns:, TAYloR \& Hovde, National Advertising in Newspapers 453-7 (1946).

206. See sources cited note 205 supra. The relation between rate and linage among dailies in multi-paper cities seems to be less striking for general than for retail advertising. Compare data in note 203 supra, zith data in note 179 supro.

207. See, e.g., Ed. \& Pub., Sept. 22, 1951, p. 16; statement in Borre:, Taylor \& Hovde, Natronal AdVERTising in Newspapers 89-90 (1946), coneerning use of smalltown dailies. For indication that agencies frequently select smaller-circulation dailies in multi-paper markets, see communications cited sufra note 196 , giving various reasons for selection, such as "class" readership, desire for dense circulation, special services, etc.

208. On allocations to small-town dailies, see Durfy, of. cit. stspra note 165 , at 71 . On allocations to smaller-circulation dailies in multi-paner markets, see communications from the Duane Jones Co., supra note 196. Occasionally, however, linage may be equal to that of larger papers in the same market. See communication from Atherton W. Hobler, supra note 196.

209. See communications from the Duane Jones Co., Atherton W. Hobler, and president of unnamed leading agency, stipra note 195.

210. "[C]ooperative advertising is regarded as any plan in which a manufacturer acts jointly with his distributors, dealers, or agents by mutual agreement, on a cost-sharing basis, to advertise the manufacturer's product." DufFy, op. cil. suspra note 165, at 271 . See id. at c. 15 for description of various plans. See also Pastez, Deizer Cooreritne Advertising, Advertising Rate Differentials, and the Robissoni-Patara: Aet (1951) (unpublished MS. on file in New York University); L (IKkLEY, Vertical CoOPERATIVE AdVERTISING (1931). 
local advertising or other sales promotion that "plugs" both the manufacturer's product and the retail outlet which markets it. ${ }^{211}$ Not only are national and local sales promotion thus harmonized, but retailers' placement of cooperative ads qualifies for the cheaper retail rate and brings the manufacturer substantial advertising cost economies. ${ }^{212}$ At present, cooperative advertising programs are largely confined to manufacturers utilizing selective distribution channels; other producers need not steer consumers to specific retail outlets. ${ }^{213}$ Yet cooperative advertising has led some publishers to eliminate the general-retail differential and adopt a one-rate policy for general and retail dealer-cooperntive advertisers ${ }^{214}$-apparently an attempt to bar a diversion of advertising sales from the high-rate general market to the low-rate retail field.

Special rate categories. While few dailies presently apply special rates to dealer-cooperative advertisers, most papers apply distinctive rates to special ad categories. ${ }^{215}$ Buyers of "classified" ad space, for example, are charged rates closer to the high general rate than to the low retail display rate. And all purchasers of legal, financial, political, theatre and amusement ads must pay more than the retail display rate in most dailies and often more than general advertising levels. Automotive advertising sometimes receives a special rate approximating the general rate, even when purchased by local retail dealers. In fact, confusion spawned by the multitude of ad content categories has led to requests that publishers streamline rate cards and bring more classifications under the retail display and general advertising headings. ${ }^{216}$

Selling techniques. Publishers who own both morning and evening dailies in the same city often attempt to maximize linage by adopting a combination sales policy. The most common technique, "forced combination" selling, compels an advertiser to buy space in both papers if he wishes to use either one. ${ }^{217}$ Publishers apply this policy more often to general advertisers than

211. Another system, used largely by automobile manufacturers, involves an assessment levy against dealers which is supplemented by manufacturer contributions and uscd for dealer-approved ads. See DuFFy, op. cit. supra note 165, at 272-6. Retailer-placcd cooperative advertising is more common than that placed by manufacturers. Bokbsis, Taylor \& Hovde, National. Advertising in Netvspapers 151 (1046).

212. Advantages and disadvantages summarized, PASTER, op. cit. supra note 210, at 24-33. Automotive manufacturers are possibly alone in their practice of placing retail ads at general rates. Borden, Taylor \& Hovde, National Advertising in Newspaptits 167 (1946).

213. Cf. id. at 165; PASTER, op. cit. supra note 210, at 14, 138.

214. See DUFFy, op. cit. supra note 165 , at $88-9$. Some papers have abolished the differential only for advertising accounts that use cooperative advertising. Ibid.

215. Information of special "classifications" from data in Newspapers Advertising Rates and Data, Dec., 1951 ; DuFFy, op. cit. supra note 165, at 89-95.

216. See, e.g., Ed. \& Pub., Feb. 16, 1952, p. 42.

217. Also known as "unit rate" selling, this practice employs a single rate covering the morning-evening insertion. Aside from morning-evening owners, it is also cmployed by publishers working under a "partial combination" plan, described at note 14 supra. 
to retailers; ${ }^{218}$ in recent years almost all morning-evening combinations were sold to general advertisers on a package basis only. ${ }^{1010}$ "Optional combination" plans, less frequent, ${ }^{220}$ attract morning-evening insertions through combination ad rates lower than the sum of both dailies' individual rates. And a few morning-evening publishers have totaled linage placed in both dailies as the measure for quantity discounts on ads placed in one of the papers. $m 1$ Finally, a publisher may forestall ad buyers' expenditures in other media by refusing to sell space except on an exclusive purchase basis.?29

Group inter-city sales and promotion programs are common in the general market. While attempts to force "package" selling of space in dailies in different cities are rare, ${ }^{223}$ more flexible programs thrive. Dailies in nonmajor cities of a single state or region often promote ad placement in several participating papers by demonstrating the advantages of their combined market areas. ${ }^{224}$ And papers under common ownership in regional or national chains conduct similar joint selling programs. ${ }^{225}$ Moreover, virtually all but the smallest-circulation dailies, whether participating in group selling programs or not, employ "special representatives" to solicit general advertising on a commission basis. ${ }^{26}$ Most "specials" serve several newspapers, often

218. See Nixon, Concentration and Abscutceism in Daily Neaspaper Ozancrship, 2 JourN. Q. 97, 112 (1945) (most recent published comparison dat2); Bonnz:, Turon \& Hovde, National Advertising in Newspapers $463-4$ (1946).

219. Brief for Defendants, p. 37, United States v. Times-Picayune Publishing Co., Civil No. 2797, E.D. La. A further indication of the widespread use of the "unit rate": an advertiser wishing to use the total nation-wide morning circulation of $21,222,525$ must also buy space in evening papers totaling $\$, 252,6 t \$ S$ circulatiun, while an advertiser wishing to use total $32,795,413$ evening circulation must gurchase an additional $8,437,570$ morning circulation. ED. \& Pub. Yearrouk 19 (1952). In all except four largest circulation groups, milline rates for papers sold in foreed combination were higher in 1941 than those of independently sold papers. Nixon, st/ra note 218 , at 111.

220. See $i d$. at 112 .

221. See, e.g., Brief for United States, pp. 345, United States v. Times-Picayune Publishing Co., Civil No. 2797, E.D. La, filed June 18, 1951.

222. See Lorain Journal v. United States, 342 U.S. 143 (1951) (upholding injunction of publisher's refusal to deal with merchants using nearby radio station; violation of Sherman Act § 2); cf. Oklahoma Publishing Co., 21 F.T.C. 798 (1935) (stipulation wherein publisher agrees to cease and desist from giving special discounts to advertisers using publisher's daily exclusively); Ed. \& Pub., Aug. 25, 1934, p. 22 (explanation of Memphis Press-Scimitar's 25\% discount to advertisers using that paper exclusively in the evening field; practice discontinued).

223. See Borden, Taylor \& Hovde, National Advertising in Newspapers 340-\$ (1946); for attitudes of package selling, see id. at 334-40. Yet syace in certain Sunday supplements used by several dailies is sold on a package basis. See id. at 223-4.

224. See id. at 310-19.

225. In a few cases, chains or groups offer discounts to buyers using all member papers. See e.g., discount allowed by Westchester Group, partly a chain. Ev. \& Pun. YEARBOOK 90 (1952).

226. In $1944,176(75 \%)$ of dailies under 5,000 circulation had no "spccial"; tut only 
located in a single area, and frequently advise their publisher clients on rate and other advertising policies.

Services to space buyers. Publishers also attempt to enhance space sales by offering special services to ad buyers. ${ }^{227}$ Dailies conduct extensive market research to ferret out consumer preferences and sales possibilities. Merchandising services, particularly for general advertisers and agencies, may plot entire sales campaigns and often seek out retail outlets for producers. ${ }^{228}$ And in presenting advertising copy, papers offer special benefits such as proferred page position, multi-color treatment, or free publicity in news columns. $^{220}$

Promotion of the newspaper medinm. The industry as a whole has participated in joint promotional programs to convince advertisers of the sales potential of the newspaper medium. Trade associations, for example, have organized research data to dramatize the impact of newspaper advertising and have placed institutional ads in newspapers. ${ }^{230}$ Publishers hope that these efforts will prevent further diversion of advertising funds into newer media, radio and television. ${ }^{231}$ Promotional efforts have aimed particularly at

59 other papers were unrepresented. BoRdEN, TAYLOR \& HOVDE, NATIONAL ADVERTISina IN NEwSPAPERS 305 (1946). A handful of larger dailies are represented solely by their own branch offices or exclusive representatives, rather than by independent "specials." $I d$. at 281 . For description of "specials" " functions, see id. at c. 14.

227. For description of merchandising and research services, see DurFy, op. cit. supra note 165, at 281-7; Borden, Taylor \& Hovde, National Advertising in Newstrupets cc. 16, 18 (1946); Ray, Competition in the Newspaper Indistry, 15 J. Markietring 444, 453-4 (1951) ; LeE, The Dally Newspaper in America 356-7 (1937). Many dailies employ special promotion staffs, who often prepare merchandising papers for advertisers. Id. at 357 .

228. Extent and expense of free merchandising services have caused frequent requests for modification by all dailies. See id. at 356 (noting A.N.P. A. adoption, in 1920, of a "Standard of Merchandising Practice for Newspapers"); BORDEN, TAYLOR \& HovdE, National Advertising in Netvspapers 406-7, 421-22 (1946).

229. These services are inducements to advertisers, although not always free. Preferred page positions sometimes cost the buyer extra; color printing is always charged for. See listings in Newspaper Advertising Rates and Data, Dec., 1951. "Split run" advertising, offered by some large dailies, permits comparison testing of two ads of identical size run in alternate copies of a single day's paper. Free publicity in nows columns ("puffs" or "Business Office Musts") may win campaign listing for a small daily, see communication from the Duane Jones Co., supra note 196, but the "puff" practice has been condemned by many publishers. See LeE, ThE DAILY NEwS'Ap'ER IN AMERICA 447-8, 470-1 (1937).

230. See description of work of A.N.P.A.'s Bureau of Advertising, in BoRDEN, TAYLOR \& Hovde, National Advertising in NewSPApers 382-5 (1946) (promotion and research activity which previously was "woefully inadequate in light of the loss of the national advertising position of newspapers." Id. at 207.) For the Bureau's ad campaign, see Ed. \& Pub., Sept. 22, 1952, p. 7 (slogan: "The newspaper is always 'first with the most"). For another promotion program, see Ed. \& Pub., Jan. 26, 1952, p. 7.

231. See note 185 supra. 
general advertisers, ${ }^{232}$ whose defection to other media has notably exceeded retailers' shifts away from dailies. ${ }^{233}$

\section{A Rationale of Advertising Rates}

Differential pricing of retail and general rates reflects publishers' expluitation of disparate demand factors in two segregated markets. While general ads do cost dailies a 15 per cent agency commission and entail selling expenses higher than for retail ads, ${ }^{234}$ these added costs account for only about half of the retail-general price differential. ${ }^{235}$ Moreover, the higher solicitation cost of general ads is partially offset by apparently higher production costs for retail advertising: general ads usually arrive at the printshop in precomposed form and are exempt from union reproduction ("bogus") requirements; retail insertions less frequently come precomposed-and when they do, "bogus" applies.236 Nor does greater frequency of retail ad placement necessarily cut publisher costs $;^{237}$ copy of large retailers usually changes from day to day, requiring fresh composition for each insertion. While retailers benefit less than general buyers from circulation beyond retail trade zones, 23 modern transport facilities enhance the customer potential of readers on the

232. Cf. Ed. \& Pub., Sept. 22, 1951, p. 62.

233. Cf. data showing relatively greater decrease in newspaper advertising of national buyers compared to local and classified buycrs from 1929 to 1941 . Bosnz:;, TayLs \& Hovde, National Anvertising in Newspapers 5 (1946).

234. Proportion of "national" (general) advertising expense to national advertising revenue is about $\mathrm{S}$ percentage points higher than proportion of "local" (principally retail) advertising expense to local advertising revenue. See Bosnex, TAyor \& Horte, Rate:ues and Expenses of Newpaper Publishers in 1941 21-2 (1946); see also tables, id. at 18. For some probable causes, see Ray, Compctition in the Nenuspaper Indtustry, 15 J. Marketring 444, 449 (1951).

235. Assume a daily has a retail rate of $\$ 1$ for retailers making 20,000 line purchases. If its selling cost percentage is $\mathbf{S}$ points higher for general ads, then this difference alone would "justify" a $\$ 1.08$ rate for general buyers of the same quantity. To account for the $15 \%$ agency commission, divide $\$ 1.08$ by .85 . The quotient, $\$ 1.27$, would be the paper's rate upgraded to account for general advertising commission and selling costs. But an average daily's differential indicates that for cities of greater than 100,000 population its general rate will actually be $\$ 1.56$, and probably close to that amount in smaller cities. See notes 166,168 supra.

236. See Ray, Competition in the Neaspaper Industry, 15 J. Mlarwetl:ic 444, 449 (1951). " [P]roduction costs for most national advertising [are] substantially less than for much of the local advertising. ..." Ibid. For indication of infrequency of precomposition (through use of mats or electrotypes) in local advertising, sce International Typographical Union, \&6 N.L.R.B. 951, 1024 n.70 (1949) (Intermediate Report). For "bogus" rules see note 128 supra.

237. One spokesman for a group of dailies has asserted that higher pruduction costs flow from the less frequent use of any given daily by general advertisers as compared to retail buyers. See Statement of C. P. Waite, quoted in PASTER, op. cif. stipra nute 210, at $59-60$.

238. "Retail Trading Zone ... [is] the area beyond the City Zone whose residents regularly trade to an important degree with retail merchants in the City Zone." Audit Bureau of Circulations, By-laws, c. C, Art. V, $\$ 4$ (A). 
periphery. ${ }^{239}$ And only a few giant dailies attract much circulation beyond the penumbra. ${ }^{240}$ The retail-general rate differential, in sum, mirrors more than sellers' costs or customer coverage differences ${ }^{241}$ it is discriminatory pricing, ${ }^{242}$ tailored to disparate price sensitivities of buyers segregated by the retail-general classification.

Although typically monopolist sellers in the retail market, publishers through lower retail rates accommodate local merchants to ensure long-term stability of retail revenues, which account for the bulk of total ad receipts. Becausc other local media do not easily meet retailer display needs, a daily's rate increases in the short run might not lose retail ad revenues.433 Yet rate controversy could end the close and cordial relationship between publishers and hometown retailers and sap a daily's good will in the local business community. And unfavorable rates could ultimately induce retailers to desert the local daily press, traditionally their favored ad medium. Publishers thus tend to behave as "benevolent monopolists" in the retail market, charging less than the "general" rate and probably less than the market could bear. ${ }^{\text {at }}$

239. See PASTER, op. cit. supra note 210 , at 53. Few dailies, in fact, attract significant circulation beyond the retail trading zone. See circulation figures in Newspaper Advertising Rates and Data, Dec., 1951.

240. New York, Chicago, and Des Moines papers are noted for their wide coverngc, "but there are sharp limits to this sort of radiation and bigness. For newspapers must remain in industry of local-and at best, regional-markets." Fouquer, NEws1'Ares Competition Today 7-8 (1951) (unpublished thesis in Economics Department, Harvard University). To some extent, moreover, the 1950 differential figure presented supra note 168 is adjusted to compensate for circulation beyond trading zones: a few of the most widely-distributed dailies do not carry retail ads in copies sent to distant areas; in computing milline rates, upon which the differential figure is based, this portion of circulation was not included.

241. PASTER, op. cit. supra note 210 , at 139 concludes that there is a "weak case" for the differential if it exceeds $25-30 \%$ See also Ray, Compctition in the Nctuspapcr 11dustry, $15 \mathrm{~J}$. MARKETING 444, 449, (1951).

242. See ibid. For another example of discrimination in the newspaper industry, see id. at 450-1, describing geographically differentiated subscription rates (higher for urban than for rural readers, whose demand is estimated to be more sensitive to price).

243. Linage might well decrease, note 170 supra, but not necessarily dollar expenditures. Cf. Ray, Competition in the Nezespaper Industry, 15 J. Marketing 444, 440 (1951). If this were the only effect, a rate rise would be profitable.

244. A somewhat different explanation, in terms of greater retailer bargaining power. is set forth in Borden, Taylor \& Hovde, National Advertising in Newspapers 438 (1946); PASTER, op. cit. supra note 210, at 52-3. Malone, Econtomic-Technologicul Bases for Newespaper Diversity, 28 Jours. Q. 315, 317 (1951) refers to "monopsonistic" buyer pressure exerted by "Chambers of Commerce and similar groups locally," but he adds, "Newspapers act, not in the fashion of orthodox monopolists taking what the traffic will bear, but as public-utility-like firms, taking a fair return on investment and some security on long-run existence instead. Monopoly profits might encourage the entry of new firms ('competitors')." Id. at 319. Malone's explanation is apparently not restricted to retail rate policy, but includes general rates as well. Ray, Compctition in the Neruspaper Industry, 15 J. Marketing 444, 447, 450 (1951) explains the differential and the low-rate retail policy in terms of publishers' estimates of relative elasticity of demaud for advertising space on the part of local and general buyers. 
And where local dailies compete in the community, publishers" low retail rates and special discounts to large retail buyers may be accentuated.245

While publishers in seeking linage in the general ad market must take account of dailies in other cities, the structure of the general market does nut induce space rate rivalry. Although rate considerations do not control advertising agencies' allocation of general advertising to individual dailies, a few papers might decide to shortcircuit ad agences, bargain directly with manufacturer-space buyers, and, in quest of greater linage, shave rates below papers with comparable circulations and markets. Such a move, however, might induce rival dailies to lower rates. From a resulting round of rate cuts no paper would gain: price reductions would not cause expansion of relatively stable advertising expenditures; the upshot might well be purchase of more space at less profitable rates. ${ }^{240}$ In this context, newspapers may find it rewarding to maintain high rates ${ }^{247}$ to general advertisers by limiting rate competition among themselves.

A system of open pricing aids avoidance of price competition. Publication of current rates and advance announcement of rate changes eliminate the possibility of individual rate fluctuations caused by sellers' uncertainty of competitors' prices;248 remind each publisher that other papers may easily" follow his rate cuts and thus "degrade" all dailies' rates; supply data for trade associations' and journals' comments and advice on prevailing rates; ;10

245. Yet merchandising and other non-price forms of competition are relied on heavily in locally competitive situations. See Ray, supra note 244 , at $453-5$, referring to both retail and general markets.

246. Cf. Ray, supra note 24 , at 445-6, (apparently referring to both retail and general buyers; but see, as to less price-sensitivity in general market, id. at 477 ).

247. Description of the general rate as "high" of course means "high" in relation to retail rates. Few publishers consider general rates "high" in relation to space value or cost.

248. Conferences of newspaper executives, at which rates are discussed, further promote communication of the rate data and rate philosophies. See, c.g., discussion by advertising managers of appropriate rate classification to be applied to Sears, Roebuck cars. Ed. \& Pub., Jan. 26, 1952, p. 63. And see Ed. \& Pub., July 1, 1950, p. 5, reporting Newspaper Advertising Executives Association meeting:

"A private conference of newspaper admen in the Northeast was held in a hotel away from the Waldorf during the week, sponsored by one New: England paper's ad manager, who was hot for an increase within the immediate future. Many Duwn East papers, however, were cagey about starting a parade."

See also note 266 infra.

249. See, e.g., Ed. \& Pub., Apr. 29, 1950, p. 13 (ANPA general manager predicts inefficacy of further rate increases); Wncox, Cossperition and Aloworoly m Arrencast InoustRy 61 (TNEC Monograph 21, 1940) ("[T] he publishers' association discourages its members from cutting advertising rates"); Ed. \& Pub., July 7, 1951, p. 30 ("Advertising rates have to go up.... The time is past when newspapers can 'sock it to' national advertisers and raise local rates moderately"-editorial); Ed. \& Pub., Aug. 25, 1951, p. 34 (noting lack of uniformity of general rates and suggesting determination by newspaper executives oi a "fair standard rate for each circulation bracket"-edituriall. See also nute $20, \mathrm{i}$ ifra. 
and enable each advertising agency to police publishers' undertakings to maintain a uniform price policy toward all.

Advertising agencies in fact insulate publishers from price-competitive pressures. Not only do agencies scrupulously guard against publishers' price concessions, but, lacking incentive to force down prices, block the ad buyer who might. Agencies stand between publishers and ultimate buyers, removing opportunity for the direct bargaining that takes place in the retail market and which might impose some competitive pressures in the general and market. Publishers, perhaps grateful for agencies' damping of rate competition as well as for their encouragement of ad expenditures, ${ }^{260}$ protect agencies' status through refusal to grant commissions to advertisers willing to perform all agency functions. And both the "recognition" system and the agencies' code preclude enterprising agencies from drilling a price leak into the general market by rebating agency commissions to clients and thus stimulating a search for price concessions.

Group or chain sales-and-promotion programs and "special representatives" soliciting ads for dailies deter aggressive rate competition among the participants. Although these alliances do not place the entire industry under one selling program, they stimulate cooperation where rate competition is perhaps most likely to arise: among newspapers serving comparable local markets in the same regional area. And with rate competition dulled by behavior of both the buying and selling parties in the general market, ${ }^{251}$ publishers rely largely on non-price methods of competition. They offer research, merchandising, and copy preparation services to space buyers, attempt to prove that their readerships are large, unique and wealthy, and stress past success in securing linage as evidence of ability to please. ${ }^{202}$

Publishers' pricing in special ad categories further supports a rationale of demand elasticity exploitation in the segregated retail and general markets. Most "classified," political, or amusement ad buyers, for example, are largely

250. See note 202 supra for list of articulated grounds for gratefulness.

251. See Ray, Competition in the Nezespaper Industry, 15 J. MARKETING 444, 445-6, 451-2 (1951) (referring to lack of price competition). But cf. Malone, Economiv" Technological Bases for Nezwspaper Diversity, 28 JourN. Q. 315, 317 (1951) (stating that newspapers in separate markets compete for national ads on the basis of market richness and milline rate). Rate competition for national advertising may be somewhat more prevalent among competitive papers in the same city than among papers in different markets. Cf. data in Nixon, Concentration and Absentecism in Daily Nezespaper Ouncrship, 22 JourN. Q. 97, 110-11 (1945), indicating that in 54 out of 97 combinations of once-competitive dailies between 1927 and 1942, the new combined rates were eçutal to or higher than the sum of the old individual rates, despite the fact that combination generally brings greater production efficiency. See note 158 sitpra. The Nixon study does not specify, however, whether general or retail rates were used, but the greater availability of general rate data indicates the former.

252. See newspapers' ads in trade publications, ED. \& PUB. YEARBook and Newspaper Advertising Rates and Data, which emphasize linage totals and readership quality or buying power, but rarely mention price. 
insensitive to the rates they pay. Price is not a significant factor where ad placements are occasional or sporadic, or do not enter into cost calculations

LABOR WAGES, NEWSPRINT PRIGES, AND MLLWE AOVERTISINO RATES: $1940-1850$

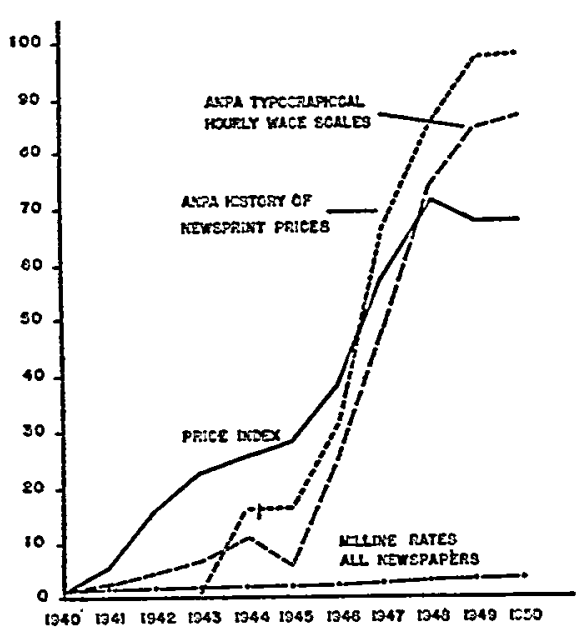

Source: Ed. \& Pub., Dec. 2, 1950, p. 5. "Price Index" is business consumers price index. Wages are for typographical employees. of doing business. 253 Publishers exact from these ad buyers rates approximating or even exceeding the high general rates: high space rates here lose few sales.

Again, lack of competition in ratemaking may account for the cyclical immobility of advertising rates. ${ }^{254}$ Although early depression years provided newspaper incentive to seek needed greater ad revenues, milline rates did not descend at all, ${ }^{255}$ and line rate declines were far outrun by price drops of other commodities. ${ }^{250}$ In later years, millines descended: small line rate rises were exceeded by circulation increases. ${ }^{237}$ In recent post-war years of business prosperity; millines again have made only gradual advances. ${ }^{253}$ Despite greatly increased linage, revenues have not matched the steep

253. One or more of these indicia of rate-insensitivity would apply to most of the thirty content categories of "classified" advertising and special "classifications" listed by the New York Herald Tribune quoted in DuFFY, of. cit. supra note 165, at 89-91, 93-5. But cf. Ed. \& Pub., Nov. 3, 1951, p. 24 (statement that "Classified Advertising is overloaded with price appeal").

254. For discussion of rigidity, see Kinter, Rigidity of Adzertising Rates in Depression and Boom Years, 24 Journ. Q. 122 (i947); Ray, Competition in the Nenespoper Industry, $15 \mathrm{~J}$. MARKETING, 444, 445-7 (1951).

255. See table in Kinter, supra note 254, at 123.

256. See analysis of line rates of 18 dailies, id. at 124-6; between 1929 and 1932 some rates were lowered but "many held firm or receded only a shade. ..." Id. at 124. Compare data in table, id. at 125-6, arith commodity prices indices for same years. Id. at 123 .

257. See id. at 122; see also graph at p. 1009 infra. There were indications during the 1929-1941 period as a whole that national rates were "even more inflesible than the local rates." Kinter, supra note 254 , at 124.

Kinter questions the "long run" wisdom of rate rigidity, particularly in light of competition from other media, id. at 126 , and wonders "whether a more flexible rate policy" would have cushioned the fall in linage during the early part of the 192y-1941 period and fostered a more pronounced recovery in the later years." Id. at 123-4. Sce, as to retail advertising, note 170 supra; but see, as to general advertising, note 185 sifpra.

258. See graph on this page. Many or most dailies have increased their line rates, see, e.g., Ed. \& Pub., Dec. 2, 1950, p. 6, but concurrent circulation increases have held 
rise in publishing costs. ${ }^{250}$ Most individual papers apparently do not dare to raise ad rates unless assured that other dailies will follow. ${ }^{200}$ And despite sutgestions for industry-wide ad rate increases, ${ }^{261}$ response has been slow. Many dailies are contemplating increases in price to the reader instead. ${ }^{202}$

Expanded utilization of dealer-cooperative advertising could stimulate rate competition in both retail and general markets. ${ }^{203}$ Cooperative plans

milline levels down. Between 1940 and 1950 general millines increased only nine cents (\$3.32-\$3.41). Ed. \& Pub., Dec. 2, 1950, p. 5. Yet increases were nore substantial for papers with less than 10,000 circulation, ibid., indicating that impact of cost pressurcs may have been more severe in the smaller circulation groups.

Besides circulation gains and lack of rate competition, see note 254 supra, recent milline rigidity may also result from increased efficiencies caused by the decline in number of dailics and growth of combination ownership, and from increase in advertising linage since 1940. Ed. \& Pub., May 17, 1952, p. 66.

259. See 1946-1950 linage figures in NEWSPRINT FOR TOMORROw, at 100 . On cost rises, see notes 68, 118, 132 supra. For comparison of increases in income and expense, see graph at p. 1008; Pollard, Spiraling Newspaper Costs Outrun Revemies, 1939-1949, 26 Jours. Q. 270 (1949) ; Ed. \& Pub., Apr. 5, 1952, p. 7 ("typical" 50,000circulation daily's 1951 net profits were lowest since 1946) ; Ed. \& Pub., Dec. 25, 1948, p. 9. For examples of recent suspensions or mergers blamed on "costs ahead of revenues," see Ed. \& Pub., July 15, 1950, p. 8 (Bakersfield, Cal.) ; July 8, 1950, p. 22 (Bloomington, Ind.); Sept. 9, 1950, p. 5 (leaving Oakland, Cal., the nation's largest one-paper city). The National Newspaper Survey stated in 1950 that half of the dailies with circulations of less than 100,000 suffered profit declines in 1949 and concluded that "rigidity in advertising rates is clearly the most important explanatory factor." Ed. \& Pub., July 1, 1950, p. 14. The survey reported a 1949 median before-taxes profit figure of $13 \%$, while the director of accounting and statistical bureau of the Newspaper Audit and Research Bureau has stated that newspapers in the under-100,000 circulation bracket need $25 \%$ profits "to meet legitimate needs." Paraphrased in ibid.

260. Although smaller dailies have raised rates further than large-circtuation papers, "[ $t]$ here has been great reluctance on the part of non-metropolitan newspaper mantagcment to raise advertising and subscription rates because of the fear of 'pricing themselves out of the market." Layman, A Report on the Financial Condition of NonMetropolitan Newspapers 26 (1949) (mimeo. presentation to the American Press Institute). Moreover this generalization was based on a study of rates for dailies "in non-competitive fields." Id. at 10. For dailies in competitive communities reluctance to lift rates may be even more marked.

261. See, e.g., statement by Erwin Canham, editor of the Christian Science Monitor, quoted in Ed. \& Pub., Apr. 5, 1952, p. 8 (suggestion directed largely toward easing the newsprint situation by discouraging use of space); editorials cited supra note 249.

262. See Ed. \& Pub., Jan. 5, 1952, p. 20. But cf. statement by chairman of the board, Bureau of Advertising, ANPA:

"Most publishers will resist as long as possible any further increase in subscription rates and with the present size of newspapers and current newsprint costs, little or no improvement may be expected through a circulation increase, even if such is possible. It seems, therefore, that we must look to advertising to help meet increasing costs and achieve, or maintain, an acceptable margin of profit." Quoted in N. Y. Times, Apr. 24, 1952, p. 34, col. 2.

263. Although recent figures on the extent of cooperative advertising are not available, manufacturers using selected distribution increased their use of the cooperative method between 1929 and 1946, and continued reliance on cooperative advertising was 
might break down the classification barrier separating general from retail buyers. Since cooperative ads are not channeled through agencies, direct buyer-seller dealing would crack the agency insulation of the bargaining parties. Direct negotiation between publishers and advertisers might well result in discreet rate concessions, undermining the structure of stable pricing in the general market. Dealer cooperative ad placement, furthermore, may actually bring a form of intercity competition into the retail market as well. Manufacturers might attempt to place cooperative ads through retailers able to secure the cheapest rates from local papers, and by selective choice of dealers bring retail rates in one locality into competition with those in another. $0 \mathrm{ct}$ Coolness of ad agencies and publishers toward cooperative advertising may thus be justified: agencies suffer lost compensation, ${ }^{205}$ while publishers, openly perturbed by falls in general linage, may also fear the future debut of widespread rate competition. ${ }^{260}$

predicted for the postwar years. See Bonden, TAYLoR \& Howe, National Aurentisritg IN NEWSPAPERS 166, 172 (1946). For manufacturers using non-selected distribution, the authors made no similar predictions, although it was estimated that "[a]bout a third of . . . mass product advertisers were . . . offering advertising allowances . . . for cooperative advertising, a great part of which was said to be expended for retail newspaper space" Id. at 97. But see Durry, op. cit. stipra note 165 , at 278 . Whatever its present extent, cooperative advertising could be further stimulated by continued increases in the general-retail differential.

264. Manufacturers, however, may not be at liherty to withdraw advertising allowances from retailers in localities where newspaper rates are "out of line." Section 2(d) of the Robinson-Patman Act may forbid payment to retailers of allowances "not available on proportionally equal terms to all other customers competing in the distribution of such products or commodities," 49 STAT. 1526 (1936), 15 U.S.C. \$13(d), although the meaning of this section is far from clear. See Rowe, Price Discrimination, Comprtition, and Confusion: Another Look at Robinson-Patman, 60 YaLE L. J. 929, 959-61 (1951). Yet manufacturers, who are assuming greater control over cooperative advertising. DUFFY, op. cit. supra note 165 , at 275,277 , could probably contract with retailers to keep cooperatively-financed ads out of "high rate" dailies.

265. "Agencies frequently plan and service cooperative advertising that is placed by dealers at local rates." "There are frequently many difficultics . . . in evolving a fair plan of agency compensation." Communication from Atherton W. Hobler, sipra note 196. In some cases "advertisers have agreed to allow the usual ageney commission on the net cost of the space used." Communication from the Duane Jones Co., supra note 196. Yet "[a]s a general answer to the attitude of agencies . . . it an be said that agencies are averse to any large part of an advertiser's total budget being spent on advertising in any form for which the agency receives little or no remuneration." Ibid. Yet effective cooperative advertising may yield larger sales "which later benefit the agencies through overall increases in the total advertising budgets." Ibid.

Lack of enthusiasm for cooperative advertising may enter into agencies" pleas for reduction of the general-retail rate differential, a major stimulant of the cooperative practice. Illustrative of agencies' attitude toward the differential were congratulations tendered the St. Louis Post-Dispatch in 1936 by the president of the A.A.A.A., when the "P-D" practically eliminated its differential. P.LSTER, op. cit. supra note 210, at 58-9. But see note 193 supra.

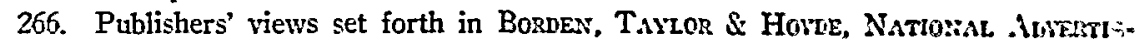
ing in Newspapers 1646 (1946). See also Paster, op. cit. supra note 210, at 42. Diver- 
Where more than one paper serves a single community, the prevailing pattern of ad marketing probably curbs the success of the smaller-circulation daily. Theoretically, milline reductions in the relatively price-sensitive retail market should gain added sales for the smaller daily. But its cost inefficiency prevents sharp rate reductions in the already low-rate retail field. The highrate general market might provide the small paper an opportunity to gain sales by rate concessions. Yet even if the paper's cost complexion permitted a rate cut, which drew no corresponding reduction from other publishers who cohesively price in the general market, ad agencies not eager for bargain rates stand between the competing publisher and his customer market. The smaller local daily, possibly hindered by "combination selling" of a morningevening competition as well, ${ }^{267}$ may thus have to content itself with ad purchases of campaign buyers planning market saturation.

Collapse of the differential price structure, possibly as a restult of widespread dealer-cooperation advertising, might not aid the smaller competing daily.208 An industry-wide shift to a one-rate policy, eliminating differential price treatment to separately classified markets, might break down the present price structure and arouse rate competition in areas now dormant; demand factors of both national advertisers and local retailers would fuse into a single rate

sion of advertising from general to retail channels means, in most cases, a smaller return for dailies. Newspaper advertising executives have discovered "there is a gencral confusion about the rate status of cooperative advertising that threatens to disrupt both the general and retail rate structures." Ed. \& Pub., Jan. 26, 1952, p. 65. Indicative of newspapers' concern for the rate structures was a recent discussion of the Interstate Advertising Managers' Association concerning rate treatment of the Sears, Rocbuck auto. Ad managers and an attending newspaper representative made these statements:

"If good newspapers would stick together on their rate structures, we would not have so much difficulty about local and national rates." "We are having trouble elsough trying to establish standard rate practices. . . . What we should do is bolster the rate structure, not tear it down." "You must be firm with your rate structure, othcrwise you are going to open a deeper grave for yourself." Ed. \& Ptb., Jan. 26, 1952, p. 63.

Yet dailies are unlikely to refuse cooperative ads, for rejection would probably antagonize retailers without necessarily inducing manufacturers to return to general advertising channels. Cf. Borden, Taylor \& Hovde, National Advertising in Newsyapens 167 (1946). And publishers have been told, "The extent to which growth of dealer cooperative advertising may be accountable for loss of national newspaper advertising during the past 15 years is not known, but evidence available indicates that it is not important relative to other causes of linage loss." Id. at 165.

267. Even if only one unit of the combination enjoys greater or "richer" circulation that the single opposing daily, forced combination selling may bring the weaker combination unit more ad linage than the single paper. The difficulty, however, of proving causal relationship between forced combination and lineage losses of the single daily is illustrated by parties' conflicting contentions in United States v. Times-Picayume Publishing Co., Civil No. 2797, E.D. La., May 27, 1952. Compare Brief for United States, pp. 22-34, zeith Brief for Defendants, pp. 39-52. See also Ed. \& Pub., May 26, 1951, p. 12 (report of argiment at Times-Picayume trial over the significance of data showing suspension of single dailies in 21 out of 45 cities where forced combination selling existed).

268. Cf. Lee, The Daily Newspaper in America 364 (1937). 
exposed to direct pressures of both major buyer classes, with competitive pricing further forced by buyers' comparison of rates in localities formerly isolated for most ad marketing purposes. But in full-scale price competition with more efficient rivals, the smaller daily's cost handicap may lessen its chances for economic survival. In fact, the smaller paper confronts a twofold dilemma: advertising market success hinges on the advantages of large circulation, but the means to expand circulation are hard to come by. Restricted access to the ingredients essential for attracting and satisfying reader demand 269 not only itself stunts circulation growth, but, coupled with inherent inefficiency in the utilization of production factors, often brands the smaller competitor a high-risk, low-return enterprise, not tempting to investors. 20 Even among non-competing dailies, smaller circulation has probably meant a smaller return on capital, as indicated by statistical estimates. 271 In com-

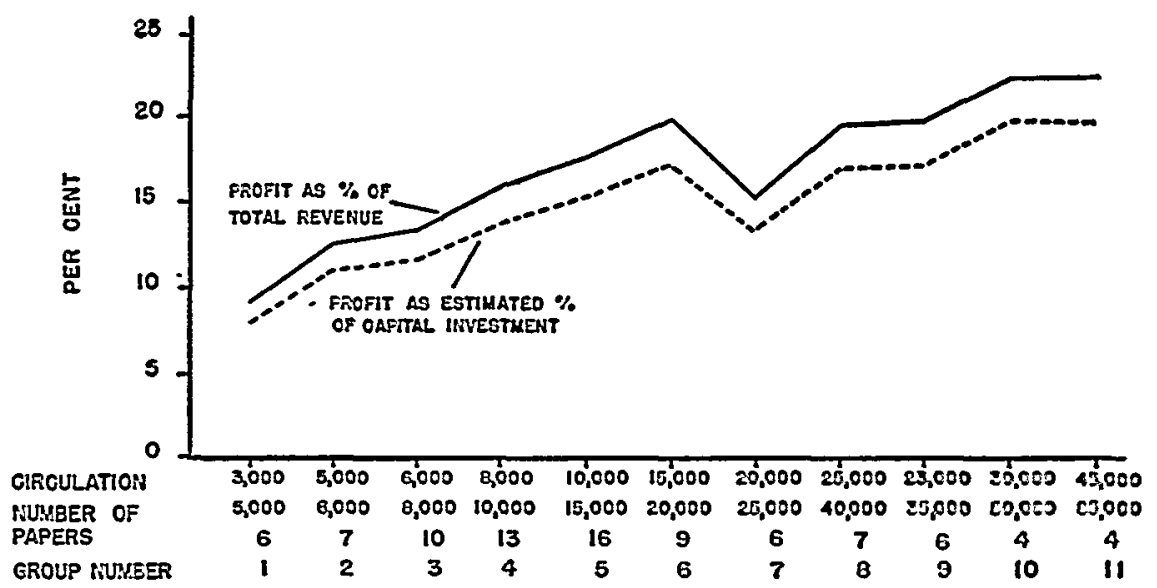

Source: Profit as a percentage of total revenue from Newspaper Audit aro REsEarcu Bureat, Spectal Stamstical Report (1950). For source of other data, see note 271 infra.

269. See discussions of newsprint, syndicated features, and wire service news, pp. 95969 supra.

270. Moreover, newspapers in general may not be deemed particularly sound credit risks. According to one estimate, only one third of insurance companies and 10 per cent of banks will consider a "good" newspaper loan, which may approximate 30 per cent of physical valuation. Advertising Age, Oct. 27, 1947, p. 83, quoted in RAy, Co:cerminstro:a of Ownership and Control in the Axierican Dathy Newspafer Industry 35 (1951) (unpublished MIS. in Columbia University Library). Cf. statements by trustee, explaining the proposed sale of Cincinnati Enquirer by the fact that newspaper business is "a hazardous one and does not constitute a proper trust investment." Ed. \& Pub., Feb. 23, 1952 , p. 13.

271. See graph on this page. Data on protit as a percentage of capital investment represent only an estimate. Since specific investment data were unavailable, estimate ui 
petitive situations as well, smaller circulation papers may be less profitable..$^{272}{ }^{*}$ And lower profitability in turn may render the smaller daily particularly vulnerable to cyclical pressures. ${ }^{273}$

Special factors can, of course, enhance the position of the smaller daily. Stratified reader markets in large cities may support a second and smaller daily, even conferring a monopoly position in a sub-market within the city..$^{274}$

capital investment drew on 1947 data of 15 non-metropolitan and non-competitive dailies with an average circulation of 30,400 ; for these papers gross income averaged $86.9 \%$ of capital investment. LAYMAN, op. cit. sitpra note 260 , at 4 . Upon advice of a leading newspaper statistician, the $86.9 \%$ figure was considered representative for all circulation groups in the graph, and computation of average investment for each group was made accordingly.

Usable investment data are rarely obtainable, since most dailies are closely held corporations and do not release financial statements. There have been, however, a few survcys of profit data other than the surveys made by Newspaper Audit and Research Bureatu, source for the graph at p. 999 infra. There are no applicable investment statistics for most of these other surveys, but their profit data show a relationship between circulation size and operating profit as a percentage of revenue similar to the relationship indicated in the graph, although the data sometimes seem erratic. See, e.g., 1941 net operating profit as percentage of total operating revenue for 73 papers:

\begin{tabular}{lccccc} 
Circ. in 1000's: & $0-10$ & $10-20$ & $20-50$ & $50-100$ & 100 or more \\
\hline Profit in \%: & 7.4 & 5.2 & 9.3 & 12.6 & 10.3
\end{tabular}

Source: Borden, Taylor \& Hovde, Revenues and Expenses of Newspaper PullLISHERS IN 194124 (1946). See aiso data in LAYMAN, op. cit. supra, at 23. For a smoother progression, see 1940 "profit before income tax" data (sample size not disclosed) in InIoN, Public Opinion and Propaganda 77 (1950). But cf. Dun \& Bradstreet, Analysis of the 1936 Operations of 90 Neinspaper Printing \& Publishing [Firms] (small) (1937) (firms ranked by dollar sales volume rather than circulation; little correlation between size and operating profit percentages).

See also Census data on value added by manufacture per employee in 1947 for 8339) newspaper establishments (dailies and weeklies) ranked according to number of cmployces rather than circulation. Value added increased fairly steadily with size, except for slight decline between the first and second groups and the last two groups. Reproduced in Ray, Economic Forces as Factors in Daily Nezuspaper Concentration, 29 JouRN. Q. 31, 35 (1952).

272. Although there is no available data on relative profitability of locally competing dailies, the relationship of profitability to circulation size for non-competitive papers presumably would apply as well in competitive situations where the smaller paper does not enjoy local market monopoly.

273. E.g., depression-induced declines in ad linage or currently spiralling costs. Sec notes 257, 259 supra. Equal percentage profit losses could be relatively more devastating for dailies whose percentage profit return was originally lower. Analysis of revente and cost rises since 1946 does not indicate substantial or consistent differences in percentage profit losses among various circulation groups of more than 10,000 circulation. See data in Ed. \& Pub., Apr. 12, 1952, p. 7. For dailies of less than 10,000 circulation, however, see note 258 supra.

274. Cf. Malone, supra note 251 , at 320 (such stratification is possible "only in . . great metropolitan centers"). Stratification may be intense in a market served by a foreign language daily or some other "special interest," limited-circulation daily. Yut these 
And some smaller, yet "growing," communities can harbor encouraging circulation and advertising prospects for an additional paper.7is Journalistic skill will also affect a competing smaller paper's economic future. The small daily can build circulation through aggressive news or editorial campaigns that outshine a larger competitor's reader appeal. And a smaller daily may climb more easily if its larger rival is editorially controlled by an absentee owner or managed by a publisher with a multitude of other interests. ${ }^{270}$

Typically, however, the structure and organization of the circulation and advertising markets exert pressure on small competing papers to suspend publication, or to combine and achieve more efficient operations. This prospect, together with the difficulties of raising initial capital, 277 will also discourage entry into the field by potential publishers. ${ }^{278}$ In short, the conditions for viable newspaper multiplicity hardly exist.

dailies do not serve the same function as a "general-circulation" daily, see note $14 \$$ supra, which can achieve a less insulated form of stratified market control by attracting adherence of a particular socio-economic class or readers of particular political orientation. Of course, in cities with only evening dailies, entrance into the morning field can bring a degree of market control, although in few cities is the morning field as popular with advertisers as the evening field. See notes 179, 180, 203 supro.

275. Cf. Neurath, Onc-Publisher Communitics: Factors Influsncing Trend, 21 Jouns. Q. 230, 232, 233 (1944) (rate of disappearance of multiplicity lover and replacement rate higher in communities increasing in population size). See also Ray, Econontic Forecs as Factors in Daily" Newispaper Concentration, 29 Jouns. Q. 31, 40 (1952). Yet "[1]oeal business trends . . . did not constitute a dominant factor in the majority of newspaper suspensions during the period 1929 through 1941." Ibid. On the influence of sectional expansion or contraction on newspaper suspension and multiplicity, sce id. at 39. Sce alse Neurath, supra, at 233, 234.

276. Absentee editorial control occasionally impedes tailoring of newsp3rer content to suit local conditions and reader desires, although generalization on this point is difficult. Cf. Nixon, Concentration and Absentecissn in Daily Newespoper Ownership, 22 JouRx. Q. 97, 105 (1945). And a publisher with diverse business activities may be inadeuately schooled in newspaper management. See Ray, Economic Forces as Factors is Daily Newispaper Concentration, 29 Jours. Q. 31, 41 (1952).

In some instances, absentee owners or publishers with other important interests suspend or merge dailies considered unprofitable more rapidly than a publisher whose sole concern is his local daily. Cf. Srmon, op. cit. supra note 45, at 90-9.

277. See note 270 stpra. For past estimates on amount of initial capital required for entry of dailies in various circulation groups, see Nine Nrearas FeLLows, op. cit. suspo note 75 , at 1846 (to operate 250,000 -circulation daily, $\$ 3-6$ million required); ICries, Anierica's House of Lorns 11 (1939); MacDougall, Newsroour Problenss arid Policies 4-5 (1941); editor's statement, in Ed. \& Pub., Dec. 27, 1947, p. 18.

278. Entry of some new general-circulation dailies, however, could come through publishing activities of large public or private institutions. The International Typographical Union. for instance, row" indirectly operates several dailies started as "strike-winning measures." Ed. \& Pub., Nov. 3, 1951, p. 9. And American Newspaper Guild members recently discussed, then abandoned a plan to foster union dailies in one-paper cities and in areas where there is a "single editorial line." See Ed. \& Pub., July 8,1950, p. 8; Oct. 14,1950 , p. 18. See also ANG promotion of plans for a national labor daily. Guild Reporter, Jan. 11, 1952, p. 4. Other possible ownerships, some of which have published dailies 


\section{Governanent Action Affecting Daily Press Concentration}

In recent years, the federal government has concerned itself with some of the obstacles impeding daily newspaper multiplicity. In some cases prevention of local press monopoly has been an express goal of government action; ;70 in other instances promotion of newspaper multiplicity has supplied only in* cidental motivation. Recent federal action has focussed on newsprint problems and on monopolistic practices of publishers and their suppliers of news and features. ${ }^{280}$

Although the newsprint industry has weathered three antitrust proceedings since $1917,{ }^{281}$ the most recent government activity has emphasized affirmative measures to increase newsprint supply and assure its distribution to publishers in need. Certificates of necessity, permitting rapid tax amortization, have been granted by the Defense Production Administration to producers planning plant expansion, ${ }^{282}$ and the $\mathrm{RFC}$ has assisted with loans. ${ }^{283}$ The Forest

in the past or do so now, include a church press (e.g., The Christian Science Monitor); municipal press; reader-sponsored dailies; cooperatively sponsored papers, such as England's Reynolds News; and an endowed press, financed like universities or research foundations.

For technological aids to new publishers, see pp. 973-4 supra.

279. "In recent years, the tendency toward concentration in the newspaper industry has been accelerated. This case seeks to call a halt to that trend." Brief for United States in Support of Motion for Partial Summary Judgment, p. 14, United States v. TimesPicayune Publishing Co., Civil No. 2797, E.D. La., filed Jan. 29, 1951.

280. The industry, however, has been directly affected by government action in at least two other areas. In October, 1951, Congress increased poundage rates on out-ofcounty second-class mail by 30 per cent, graduated in annual 10 per cent increases. 65 Stat. 672 (1951), 39 U.S.C.A. \& 289a (Supp. 1952). See note 152 supra. And in 1947 the General Counsel of the NLRB issued a complaint charging that the International Typographical Union demands for "bogus" violated $\$ 8(b)(6)$ of the Taft-Hartley Act, which brands as an unfair labor practice exaction of payment for services "not performed or not to be performed." The Board, however, held that in view of "the clear congressional intent to limit and restrict the application of this section," "bogus" was not proscribed by $\S 8$ (b) (6). International Typographical Union, 86 N.L.R.B. 951, 959-60 (1949), aff'd in part sub nom, American Newspaper Publishers Association v. NLRB, 193 F.2d 782, 801-2 (7th Cir. 1951).

281. In 1917, the Justice Department brought criminal and civil suits against leading newsprint firms, alleging various competitive restraints. See reproduction of indictment and petition for decree, in Monopoly Power Hearings, Pt. 6-B, at 82, 87. Defendants entered nolo contendere pleas and submitted to fines and a consent decree dissolving their trade association and enjoining certain activities. NEwSpRint PAPER Decree INvestiaATTON, op. cit. supra note 86, at 36-7. In 1939 new antitrust proceedings struck at West Coast producers charged with price-fixing. See indictment at Monopoly Power Hearings, Pt. 6-B, at 93. Once more, nolo pleas and fines resulted. United States v. Crown Zellerbach Corp., No. 26680-S, S.D. N.Y., May 2, 1941. In 1947 the Justice Department entered upon a sweeping grand jury investigation, soon dissipated by Canadian industry members' refusal to comply with subpoenas demanding their documents, and by ensuing international implications. See H.R. ReP. No. 505, at 58; Monopoly Power Hearings, Pt. 6-B, at 7-14.

282. See note 99 supra.

283. See letter from RFC, quoted in Monopoly Pozver Hearings, Pt. 6-A, at 582. 
Service has facilitated development of substitute production processes. ${ }^{234}$ The National Production Authority sponsors voluntary newsprint conservation programs, and, without imposing an allocation plan, seeks newsprint stocls for distressed dailies. ${ }^{285}$ Congressional committees have held lengthy inquiries to discover other means to enhance the newsprint supply $;^{290}$ their recommendations include government support, through timber resource development, of an Alaskan newsprint industry, ${ }^{287}$ and longer and larger loans to publishers investing in cooperative newsprint ventures. $2 \$ 8$

The Justice Department by antitrust proceedings has attempted to ease publishers' access to wire news and feature syndicates. The Associatcd Press suit, decided by the Supreme Court in 1945, forced AP to eliminate discriminatory admissions requirements imposed on publisher-applicants competing with member dailies. ${ }^{289} \mathrm{By}$ the terms of the decree, however, AP retained freedom to turn away applicants so long as denials were not based on competitive considerations. ${ }^{290}$ Although one AP member has suggested that a court decree cannot instill completely objective attitudes toward competing applicants, ${ }^{291}$ recent rejections have not been labeled an abuse of the discretion left with the association under the decree. In the feature syndicate field, after "territorially exclusive" sales and syndicate-chain integration had been challenged in private antitrust actions, ${ }^{292}$ the Justice Department opened a grand jury investigation of syndicate practices in late $1951,{ }^{203}$ with results not yet made public.

Publishers" "forced combination" and "exclusive dealing" ad sales policies have also provoked recent antitrust action. In United States $v$. Timos-Picayune Publishing Co., the Justice Department proceeded against a New Orleans morning-evening combination which sold general and classified space only in

284. See communication from H. R. Josephson, stpra note 101.

285. See Newsprint for TonorRow, at 173-5.

286. See voluminous list of pre-1950 hearings, and reports in Monopoly Pourr Hcarings, Pt, 6-B, at 213-17.

287. See H.R. REP. No. 505, at 129-30. See also note 85 supro.

288. See Newsprint fOR Tossorrow, at 10-11; note 98 supra. This proposal conflicts with suggestions for consideration of "separation of pulp business from publishing." ERNST, THE FIRST FreEDOAS 265 (1946).

See also proposals of House Subcommittee on Monopoly Power, both for antitrust and "measures to obtain new production," in H.R. KEP. No. 505, at 123-32. For attempted compilation of all legislative proposals concerning newsprint, see Newspru:is FOz TOArorkow, at 25-6. See also discussion of 20\% tax on advertising expenditures aimed partly at reducing newsprint use. Ed. \& Pub., Apr. 7, 1951, p. 16.

259. See "prerequisite[s] to election" listed as " $\mathrm{a}$ " and " $\mathrm{b}$," Associated Press v. United States, 326 U.S. 1, 10-11 (1945). For description of their operation, see 2 CrAsEE, Governasent AND MIAss CoNrsunications 542-4 (1947).

290. See note 116 supra.

291. Confidential interview with AP member.

292. See cases cited in notes 107,110 supra.

293. See Ed. \& Pub., Sept. 22, 1951, p. 13. 
a morning-evening package. ${ }^{204}$ A federal district court ruled that defendants' ad contracts "effect[ed] tying-in sales" in violation of Sections 1 and 2 of the Sherman Act. The court, however, did not brand forced combination selling a per se Sherman Act violation. ${ }^{205}$ It emphasized that one of the two combination dailies ("the tying product") enjoyed a monopoly in the morning field and was almost indispensable to advertisers, many of whom had limited budgets. Thus the court found that selling the morning daily in a unit with its evening sister restrained "a substantial portion" of the ad market in New Orleans. Moreover, the court cited evidence indicating that combination selling deprived the combination's evening competitor of some linage it might otherwise have received, and other evidence showing defendants' specific

294. United States v. Times-Picayune Publishing Co., Civil No. 2797, E.D. La., May $27,1952$.

The complaint, filed June 14, 1950, alleged "that (a) the defendant corporation has entered into . . . a series of contracts with advertisers in unreasonable restraint of trade in newspapers, news, advertising, supplies and nationally advertised products in violation of Section $1 \ldots$ and (c) all the defendants ... are attempting to monopolize the dissemination of news and advertising through newspaper channels in violation of Section 2. . . " Brief for United States, filed June 18, 1951, pp. 1-2. The government sought relief under § 4. Id. at 2-3.

295. In early 1951, the government moved for partial summary judgment. Sce Bricf for United States in Support of Motion for Partial Summary Judgment, United States v. Times-Picayune Publishing Co., Civil No. 2797, E.D. La., filed Jan. 29, 1951. In its brief, the government challenged, in addition to general and classified advertising contracts, defendants' local display advertising contracts, which credited, for discount purposes, linage placed in the morning daily to ads bought in the evening unit. The government asserted that in International Salt Co. v. United States, 332 U.S. 392 (1947), the Supreme Court "established the doctrine that tie-in sales of this type foreclosing competitors from a substantial market are unlawful per se..." Brief for United States in Support of Motion for Partial Summary Judgment, supra, p. 25. And the general and classified contracts were analogized to practices involved in the International Salt case, supra (tic-in sales); United States v. Paramount Pictures, 334 U.S. 131 (1948) ("block-booking"); and in United States v. Griffith, 334 U.S. 100 (1948) (use of circuit buying power). Brief for United States in Support of Motion for Partial Summary Judgment, supra, pp. 17-23. Partial summary judgment might have labelled forced combination selling and defendants' local display practice a Sherman Act violation without evidence of intent or actual cffect on competitors. Yet the motion was denied. Ed. \& Pub., Feb. 24, 1951, p. 11.

At trial, the government buttressed its contentions with evidence of intent and exclusion, stating, in its $\S 2$ argument: "The intent and effects have been shown by (1) [defendants'] purchase of the competing States in 1933 ; (2) their adoption of the unit rate for classified advertising in 1935; (3) their operation of the States (evening) at a loss since 1948 while making profits from the operations of the Times-Picayune (morning and Sunday); and (4) their adoption of the unit rate on general advertising and (5) their interference with distribution of their remaining competitor's newspapers in 1949-50. . ." Bricf for United States, p. 92, United States v. Times-Picayune Publishing Co., Civil No. 2797, E.D. La., filed June 18, 1951. But see Brief for Defendants, pp. 97-106. The district court, however, rejected contentions (1), (3), and (5), United States v. Times-Picayune Publishing Co., Civil No. 2797, E.D. La., May 27, 1952, pp. 12-14, 19-20; it relied on contentions (2) and (4), together with the evidence of intent and effect summarizcd in the text immediately following. 
intent "to diminish the competitive vigor" of their lone competitor. ${ }^{208}$ In another recent antitrust proceeding, Lorain Joumal Co. v. United States, the Supreme Court upheld a decree enjoining an Ohio daily from refusing to sell ad space to local merchants who bought advertising time on a nearby radio station. Where the injured news medium, however, is a competing daily, Lorain Journal might not apply: the Supreme Court, holding defendant's conduct an "attempt to monopolize," emphasized the Journal's past "substantial monopoly" in the dissemination of news and ads in the area, ${ }^{208}$ and its present market leverage through "complete daily newspaper monopoly of local advertising."299

Although the government may broaden its recent actions, 300 these thrusts cannot reach the dominant cause of local newspaper monopoly: competitive efficiencies of large circulation size. This fundamental economic circumstance, in fact, rules out traditional government measures of curbing monopoly power: :01 Sherman Act separation of combination ownership or Clayton Act

296. United States v. Times-Picayune Publishing Co., Civil No. 2797, E.D. La, Mray 27,1952 , pp. 6-7, 15 (morning daily's dominance), 17-18 (market restraint), 8, 10-11 (effect on competitor's linage), 9-10, 15-16 (intent).

As this Comment went to press, the court was awaiting submission by the government of a proposed form of decree.

297. 342 U.S. 143 (1951), affirming 92 F.Supp. 794 (N.D. Ohio 1950).

298. Lorain Journal v. United States, 342 U.S. 143, 150-1 (1951). This "substantial monopoly" lasted from 1933 to 1948 , when WEOL entered upon the scene.

299. Id. at 149. But a Chattanooga, Tenn, daily, with competition in its afternoon field, was found guilty by a federal jury under an information (filed in 1940) charging Sherman Act violation through use of contracts requiring advertisers to use defendant exclusively in the afternoon field. The case, not reported, is described in Brief for United States in Support of Motion for Partial Summary Judgment, p. 18 n.2, United States v. Times-Pacayune Publishing Co., Civil No. 2797, E.D. La, filed Jan. 29, 1951. Sce also Oklahoma Publishing Co., 21 F.T.C. 798 (1935), stpra note 222.

In 1936 the FTC condemned other publisher advertising behavior: cutting rates below "cost," coupled with distribution of free copies and making of "disparaging" remarls in attempt to injure competitor. Blackwell Journal Publishing Co., 23 F.T.C. 413 (1936) (cease and desist order).

300. Possible extension could include adoption of some of the newsprint proposals listed in NewSPRINT FOR TOMrorrow, at 25-6; Justice Department inspection of UP and INS "asset value" contracts, supra p. 969; antitrust attack on forced combination ad selling in cities other than New Orleans. See p. 989 supra and note 219 supra; if necessary, amendment of $\$ 3$ of the Clayton Act to bring sales of ad space within its coversge and permit the government to use it in possible future forays against forced combination policies.

301. Cf. 2 Chafee, Governasent and Mlass Coxmunicatioss 650-3 (1947), doubting that antitrust laws can do more than to remove "artificial barriers" to the growth of "independent instrumentalities of communication." See also id. at 618-24, stating that "breaking up bigness" will not make "the press give us what we want from it" in level of performance or diversification of views. "[T] he Sherman Act recedes. You stop expecting that a few lawyers in the Department of Justice and a statute passed in $1890 \mathrm{can}$ do much to make the press of 1950 what you desire." Id. at 653 . 
preclusion of incipient mergers could not eliminate the economic forces pressing for newspaper fusion. ${ }^{302}$ And because available legal instruments are inadequate, only drastic government policies permanently equalizing large and small dailies' competitive prowess can foster daily-press multiplicity. ${ }^{303}$

302. In $1950, \S 7$ of the Clayton Act was amended to prohibit corporate acquisition not only of another corporation's stock but also of its assets, where "in any line of commerce in any section of the country ... the effect ... may be substantially to lessen competition, or to tend to create a monopoly." § 7, Clayton Act, 38 STAт. 730, 731 (1914), as amended, 15 U.S.C.A. \& 18 (Supp. 1952). Prior to the amendment's passage one of its sponsors, Rep. Emanuel Celler (N.Y.), stated, "I think this act might be construed to prevent newspaper merger. . . . In any community there should be a clash of opinion." Ed. \& Pub., Sept. 17, 1949, p. 34. Yet application of $\$ 7$ to newspaper mergers will probably be limited by case law holding that the section does not bar a failing business from selling out, International Shoe Co. v. FTC, 280 U.S. 291, 302-3 (1930), and by statements to the same effect in a House committee's report on the proposed amendment. H.R. REP. No. 1191, 81st Cong., 1st Sess. 6 (1949). Moreover, the substitution of "in any section" for "section or community" as the locus of competitive diminution, ibid., might make application of $\$ 7$ to small-town newspaper mergers difficult, although Rep. Celler has stated, 'I don't believe the wording 'in any section of the country' would be limited so narrowly to prevent its being applied to local situations providing interstate commerce were to some extent involved." Communication to the Yale Law Jounnal. from Rep. Emanuel Celler (N.Y.), dated Nov. 15, 1951, on file in Yale Law Library.

For state action against newspaper combination, see Ed. \& Pub., Feb. 17, 1951, p. 13, Feb. 24, 1951, p. 60 (Georgia anti-monopoly legislation passes Senate but not Hotse; backed by Gov. Herman Talmadge and supposedly aimed at Atlanta Journal and Constitution combination ownership); Ed. \& Pub., Mar. 20, 1948, p. 7 (Virginia House of Delegates resolution asking investigation of "question whether or not it is deemed in the public interest that the only two papers ... in ... Richmond shall be owned by one corporation") ; Ed. \& Pub., Apr. 5, 1947, p. 34, June 28, 1947, p. 57 (Wisconsin law prohibiting newspapers from combining to fix prices or restrain trade; Madison dailies, in "partial combination" plan, claim law aimed at them).

303. The following sources contain descriptions of proposals for legislative or administrative action aimed at assisting either small dailies or smaller competing dailies:

"Incentive taxation" exempting from income tax the first " $\mathrm{X}$ " thousand dollars of annual profits. See ERnst, The First Freedom 254-5 (1946); Royal Commission on THE PRESS, REPoRT 160 (1949).

Sliding scales of postal rates, inoreasing with circulation size and giving small dailies a cheaper rate than at present. Survival of a Free, Competitive Press, at 53; Ennst, The FirST FREEDOM 258-9 (1946).

Government purchase of space in small dailies and weeklies to advertise bonds, notes, and other obligations, proposed in a war-time bill introduced by Sen. John H. Bankhcad (Ala.). See Hearings before the Senate Committee on Banking and Currcncy on S. 1457, 78th Cong., 1st Sess. (1943).

Establishment of a public corporation to print new newspapers under "contract" and thus reduce capital requirements. See Royal Commission on tHe Press, Report 158 (1949).

Reconstruction Finance Corporation reversal of its policy against extending credit to publications. See Survtval of a Free, Competitive Press, at 55-7.

Amendment of the Robinson-Patman Act to cover advertising, see Ed. \& Pub., July 1, 1950 , p. 9, possibly on the theory that smaller papers are less able to justify discounts, that the discounting system, see note 165 supra, thus injures "competition" among newspapers. The FTC has stated that "advertising space" is not a "commodity" under the Act, FTC 


\section{CoNCLUSION}

Examination of the daily-newspaper industry reveals a profound dilemma: economic competition may stifle competition in the marketplace of ideas. Since newspaper size is efficiency, the smaller competing daily which could supply diversity of opinion and news presentation is consistently handicapped in its struggle for independent survival. Yet press multiplicity, as a goal of public policy, at present is little more than an article of faith, resting on a theoretical foundation. ${ }^{304}$ Comprehensive research utilizing modern techniques of content, audience, and effect analysis could force contrary conclusions, or at least furnish more precise guides for government action. ${ }^{305}$ Drastic attempts to reverse economic trends and restructure the industry should await further scientific exploration of the impact of local press monopoly on democratic processes in the community.

Informal Opinion, S1st Cong. Rec. 2336 (1937) (Appendix), and the Commission has instituted no proceedings involving charges of rate discrimination. Communication to the YaLe Law Jourdal from W. T. Kelley, General Counsel, FTC, dated Nov. 15, 1951, on file in Yale Law Library. But for a recent private action alleging rate discrimination against theatre owners by New York dailies, see Trebuhs Realty Co. v. News Syndieate Co., 1950-51 TRADE CASES $\Uparrow 62,951$ (S.D. N.Y. 1951) (motion to separate denied).

Dissolution of chains, against which "the independent operator . . cannot compete." ERNST, The FirSt Freedour 252 (1946). See note 159 supra.

There have also been proposals for compelling diversification of opinion in newspapers, whether competitive or not, through a National Press Authority compelling presentation of views on all sides of public questions. See Ed. \& Pub., Mar. 3, 1951, p. 6S; 2 Crarze, Governament and Mass Cominunicatrons 694-6 (1947).

For criticism of many of these proposals and lengthy examination of role of government in improving communication of news and ideas, see id. at cc. $23,24$.

304. See pp. 951-9 supra.

305. For list of studies in science of content analysis, see Lasswell, Policy and the Intelligence Function in Propaganda in WaR aNd Crisis 55, 68 n.9 (Lerner ed. 1951). See also Lasswell \& Leites, Language of Politics (1949). Analysis of newspapers in five cities was undertaken a few years ago by Columbia University's Bureau of Applied Social Research. For tentative conclusions concerning one of these cities, see Bigman, supra note 41.

For examples of audience analysis, see studies in Lazarsfeid, Radio asd tze Pronted PAGE (1940).

For references to works on effect analysis, see bibliography in KLAppes, TaE Erfects of MAss Mrdia (1949); Schramm, The Effects of Mass Commusicalions: A Recinw, 20 JouRr. Q. 397, 398-400 (1949). For detailed description of controlled effect studies, see Horland, Lunsdatne \& Sheffield, Experimients on Mass Consulevicitua: (1949).

For a classic study which combined all three types of analysis, see LAzarsfend, Benerson \& Gaunet, The People's Chorce (1944) (study of how Erie Cuunty, Ohio, vouters made up their minds in 1940 presidential campaign). 


\section{FOUR-YEAR RECORD OF REVENUE AND COST RISES}

$$
1946=100
$$
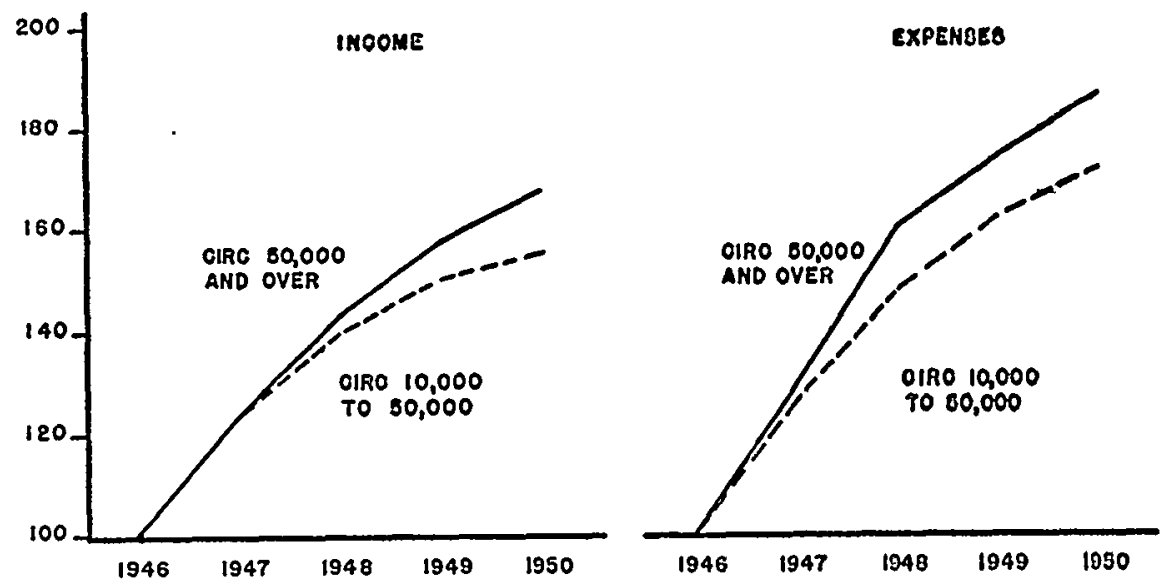

Source: Computed from data in Ed. \& Pub., Apr. 7, 1951, p. 5.

WAGE AND SALARY COST PER PAGE

PER 1000 CIRCULATION FOR 95

NON METROPOLITAN DAILIES, 1950

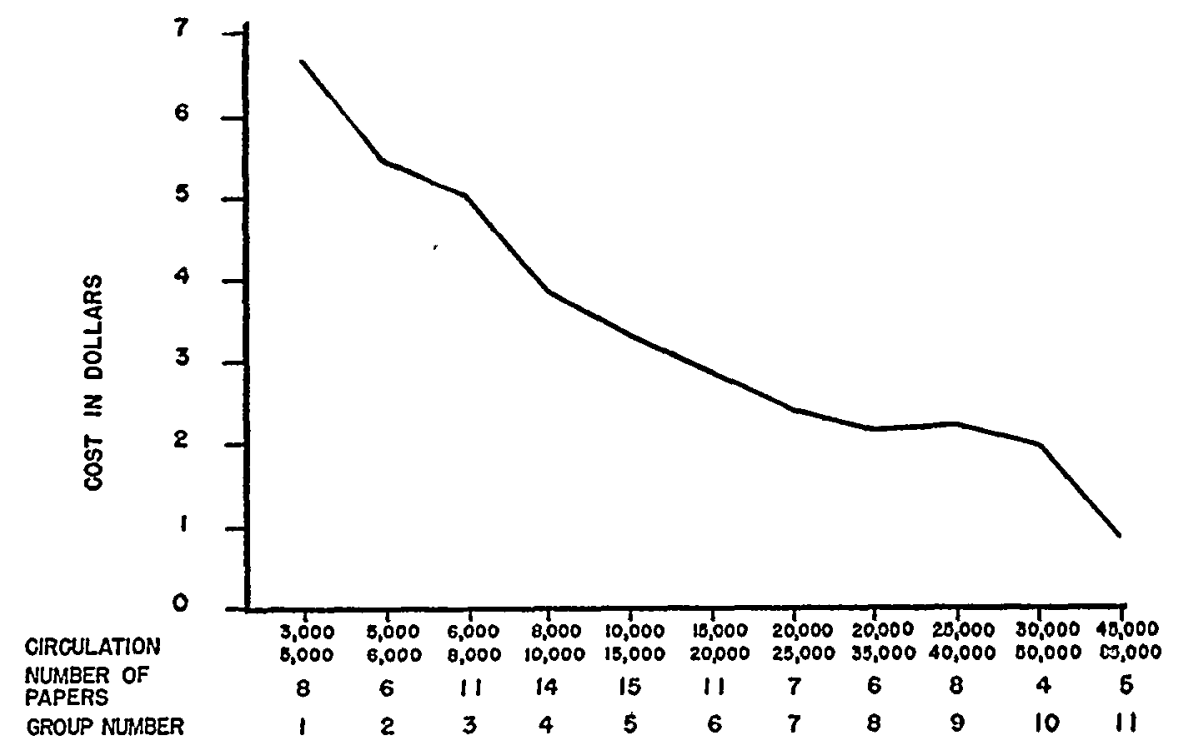

Source: Computed from data in Newspaper Audit and Researcu Burenu, Special. Statistical Report (1951). See note 149 silpra. 
DAILY RETAIL AND GENERAL MILLINE RATES FOR 20,000 LINE PURCHASES FROM AUDIT BUREAU CIRCULATION NEWSPAPERS IN CITIES OVER 100,000 POPULATON

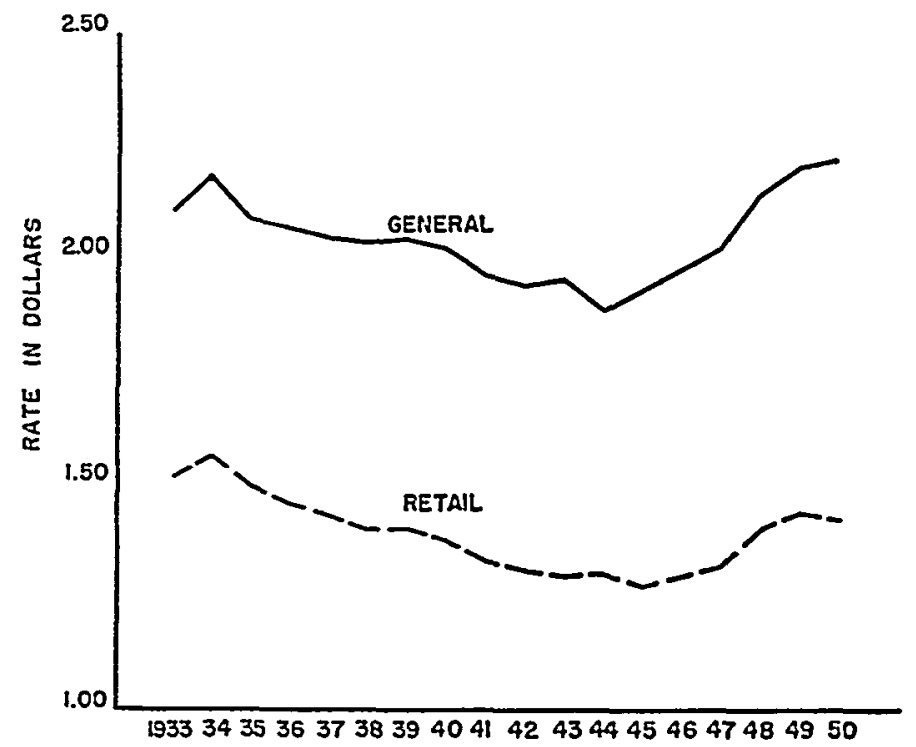

Source: Data provided by confidential source. For actual figures, see note 168 supra. This graph and all other graphs in this Comment were drawn by Mr. Ronald L. Fluctser of the Yale University School of Engineering. 